\title{
ATRIBUTOS BIOQUÍMICOS COMO INDICADORES DA QUALIDADE DE SOLO EM FLORESTAS DE Araucaria angustifolia (Bert.) O. Ktze. NO ESTADO DE SÃO PAULO
}

FERNANDA DE CARVALHO

Dissertação apresentada à Escola Superior de Agricultura "Luiz de Queiroz", Universidade de São Paulo, para obtenção do título de Mestre em Ecologia de Agroecossistemas.

P I R A C I C A B A

Estado de São Paulo - Brasil

Junho - 2005 


\section{ATRIBUTOS BIOQUÍMICOS COMO INDICADORES DA QUALIDADE DE SOLO EM FLORESTAS DE Araucaria angustifolia (Bert.) O. Ktze. NO ESTADO DE SÃO PAULO}

\section{FERNANDA DE CARVALHO}

Engenheira Florestal

Orientadora: Prof ${ }^{a}$. Dr ${ }^{\mathrm{a}}$ ELKE JURANDY BRAN NOGUEIRA CARDOSO

Dissertação apresentada à Escola Superior de Agricultura "Luiz de Queiroz", Universidade de São Paulo, para obtenção do título de Mestre em Ecologia de Agroecossistemas.

P I R A C I C A B A

Estado de São Paulo - Brasil

Junho - 2005 
Dados Internacionais de Catalogação na Publicação (CIP) DIVISÃO DE BIBLIOTECA E DOCUMENTAÇÃO - ESALQ/USP

Carvalho, Fernanda de

Atributos bioquímicos como indicadores da qualidade de solo em florestas de Araucaria angustifolia (Bert.) O. Ktze. no Estado de São Paulo / Fernanda de Carvalho. - - Piracicaba, 2005.

79 p. : il.

Dissertação (mestrado) - - Escola Superior de Agricultura Luiz de Queiroz, 2005. Bibliografia.

1. Araucária 2. Bioquímica do solo 3. Solo florestal 4. Solos - Qualidade I. Título

CDD 634.975

"Permitida a cópia total ou parcial deste documento, desde que citada a fonte - O autor" 


\title{
DEDICO
}

\author{
À DEUS \\ Por ser a sombra fresca \\ que me cobriu durante todos estes dias.
}

À MINHA FAMÍLIA.....

\author{
Antonio Duque de CARvalho \\ JoElina DE OliVEIRA CARVALHO \\ JACQUELINE APARECIDA DE CARVALHO \\ AlessandRa CARVALHO
}

....por ser meu alicerce e exemplo de amor. AMO VOCÊS!

\section{OFEREÇO}

ao companheiro desta jornada

EDWARD LUIS GODOY 


\section{AGRADECIMENTOS}

Primeiramente gostaria de agradecer a ESALQ/USP pela oportunidade de realizar este curso de mestrado devido a inigualável sensação das descobertas desta aventura!

Assim como tudo na vida existe um cenário e seus personagens que fazem à história acontecer, e é pra eles que vão o meu agradecimento.

Primeiramente a Professora Elke J.B.N. Cardoso que representa pra mim muito mais do que ela imagina, obrigada por tudo!

Aos queridos do laboratório Denise e Fernando pela ajuda e principalmente por estes anos de convivência que trouxeram muitas alegrias e conforto.

À Regina Cellis e Eliana Navas por toda paciência e dedicação.

Às professoras Marli de Fátima Fiore, Tsai Siu Mui e Maria Victoria Ramos Ballester, pelas contribuições.

Aos Professores Carlos Tadeu dos Santos Dias e Jairo Antônio Mazza pela ajuda nas análises estatísticas e classificação do solo respectivamente.

Aos funcionários do departamento de solos e nutrição de plantas, Dorival, João, Luís, Leandro, Jakeline, Karina, Udso, José, Martinha e as meninas da limpeza.

À FAPESP pela bolsa concedida.

Ao Antônio Modesto Pereira e ao Tadeu Gonçalves pela hospitalidade apoio e amizade e a enorme dedicação de todos vocês a este lugar maravilhoso, parabéns a todos!

Ao departamento de solos e nutrição de plantas em especial ao laboratório de microbiologia do solo da UFLA e a professora Fátima M.S. Moreira pelo apoio e a oportunidade das realizações das análises de enzimas! 
Aos amigos conquistados que fizeram parte desta história Valzinha, Renata, Carol, Dilmar, Dani, Alessandra, Débora, Paulo, Pereira, Célia e Alexandre.

Aos amigos de longe, mais de sempre.

E finalmente aos bichinhos da minha vida! 


\section{SUMÁRIO}

Página

LISTA DE FIGURAS............................................................................... viii

LISTA DE TABELAS............................................................................................. xi

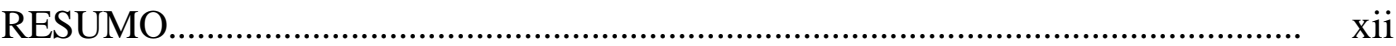

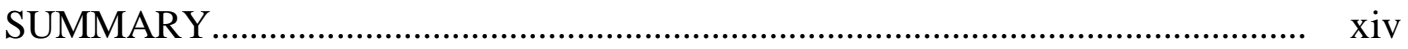

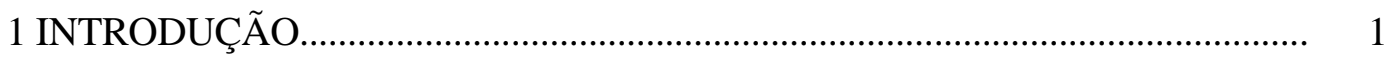

1.1 Objetivos gerais..................................................................................................... 4

1.2 Objetivos específicos........................................................................................... 4

2 REVISÃO DE LITERATURA..................................................................... 5

2.1 Araucaria angustifolia (Bertoloni) Otto Kuntze..................................................... 5

2.2 Qualidade do solo........................................................................................... 9

2.3 Importância da matéria orgânica do solo e suas modificações................................. 11

3 MATERIAL E MÉTODOS.................................................................................. 16

3.1 Descrição das áreas de estudo.............................................................................. 16

3.1.1 Áreas do Parque Estadual Turístico do Alto do Ribeira -PETAR....................... 17

3.1.2 Áreas do Parque Estadual de Campos do Jordão- PECJ...................................... 21

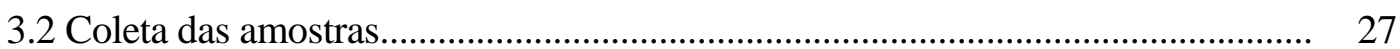

3.3 Análise granulométrica e avaliação dos atributos químicos.................................. 27

3.3.1 Determinação do carbono total do solo............................................................. 28

3.3.2 Determinação do nitrogênio total do solo....................................................... 29

3.4 Avaliação dos atributos bioquímicos......................................................................... 31

3.4.1 Carbono da biomassa microbiana................................................................... 31

3.4.2 Nitrogênio da biomassa microbiana........................................................................ 32 
3.4.3 Respiração Basal......................................................................................... 33

3.4.4 Quociente metabólico................................................................................. 34

3.4.5 Determinação da hidrólise do diacetato de fluoresceína (FDA)........................ 34

3.4.6 Determinação da atividade da $\beta$-glicosidase....................................................... 36

3.4.7 Determinação da atividade da urease............................................................ 38

3.5 Avaliação estatística dos dados.............................................................................. 39

4 RESULTADOS E DISCUSSÃO................................................................... 40

4.1 Atributos físico químicos........................................................................... 40

4.2 Atributos bioquímicos........................................................................................ 45

4.2.1 Carbono e nitrogênio da biomassa microbiana..................................................... 45

4.2.2 Respiração Basal e quociente metabólico............................................................ 52

4.2.3 Atividade enzimática........................................................................................... 57

4.2.3.1 Atividade da urease.................................................................................. 57

4.2.3.2 Hidrólise do diacetato de fluoresceína (FDA)................................................... 61

4.2.3.3 Atividade da $\beta$-glicosidase........................................................................ 64

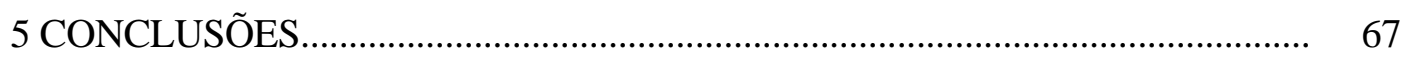

REFERÊNCIAS BIBLIOGRÁFICAS............................................................... 68 


\section{LISTA DE FIGURAS}

Página

1 Localização dos Parques Estaduais dentro do Estado de São Paulo.

2 Aspecto geral da Mata Nativa do PETAR - MNP (A) e aspecto da cobertura do solo da Mata Nativa do PETAR - MNP (B).

3 Aspecto geral da Mata Plantada do PETAR - MPP (A) e aspecto da cobertura do solo da Mata Plantada do PETAR - MPP (B).

4 Aspecto geral da Mata Nativa da Barra do Chapéu - MNBC (A) e aspecto da cobertura do solo da Mata Nativa da Barra do Chapéu - MNBC (B).....

5 Ocorrência de fogo recente, porém de baixa intensidade no inverno na Mata Nativa da Barra do Chapéu - MNBC 19

6 Diagrama climático referentes aos ecossistemas estudados do PETAR. 21

7 Aspecto geral da Mata Nativa do PECJ - MNCJ (A) e aspecto da cobertura do solo da Mata Nativa do PECJ- MNCJ (B)

8 Aspecto geral da Mata Plantada com ocorrência de incêndio do PECJ - MPCJi (A) e aspecto da cobertura do solo da Mata Plantada com ocorrência de incêndio do PECJ - MPCJi (B).

9 Aspecto geral da Mata Plantada do PECJ - MPCJ (A) e aspecto da cobertura do solo da Mata Plantada do PECJ - MPCJ (B)

10 Diagrama climático referentes aos ecossistemas estudados do PECJ................. 26

11 Esquema dos três pontos de coleta sob a copa da araucária............................... 27

12 Expressão gerada através do gráfico para o cálculo da concentração de nitrogênio.

13 Expressão gerada através do gráfico para o cálculo da concentração de fluoresceína produzida. 
14 Expressão gerada através do gráfico para o cálculo da concentração de $\rho$ nitrofenol produzido

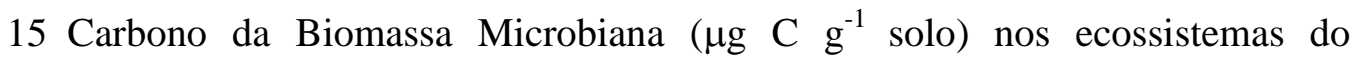
PETAR: Mata Natural do PETAR (MNP), Mata Natural da Barra do Chapéu (MNBC) e Mata Plantada do PETAR (MPP) nas estações de verão e inverno.... 48

16 Carbono da Biomassa Microbiana ( $\mu \mathrm{g} \mathrm{C} \mathrm{g}^{-1}$ solo) nos ecossistemas do PECJ: Mata Natural de Campos do Jordão (MNCJ), Mata Plantada de Campos do Jordão (MPCJ) e Mata Plantada de Campos do Jordão com ocorrência de incêndio (MPCJi) nas estações de verão e inverno

17 Nitrogênio na Biomassa Microbiana ( $\mu \mathrm{g} \mathrm{N} \mathrm{g}^{-1}$ solo) nos ecossistemas do PETAR: Mata Natural do PETAR (MNP), Mata Natural da Barra do Chapéu (MNBC) e Mata Plantada do PETAR (MPP) nas estações de verão e inverno.... 50

18 Nitrogênio na Biomassa Microbiana ( $\mu \mathrm{g} \mathrm{N} \mathrm{g}^{-1}$ solo) nos ecossistemas do PECJ: Mata Natural de Campos do Jordão (MNCJ), Mata Plantada de Campos do Jordão (MPCJ) e Mata Plantada de Campos do Jordão com ocorrência de incêndio (MPCJi) nas estações de verão e inverno.

19 Respiração Basal (mg $\mathrm{CO}_{2} \mathrm{~g}^{-1}$ solo $\mathrm{h}^{-1}$ ) nos ecossistemas do PETAR: Mata Natural do PETAR (MNP), Mata Natural da Barra do Chapéu (MNBC) e Mata Plantada do PETAR (MPP) nas estações de verão e inverno.

20 Respiração Basal (mg $\mathrm{CO}_{2} \mathrm{~g}^{-1}$ solo $\mathrm{h}^{-1}$ ) nos ecossistemas do PECJ: Mata Natural de Campos do Jordão (MNCJ), Mata Plantada de Campos do Jordão (MPCJ) e Mata Plantada de Campos do Jordão com ocorrência de incêndio (MPCJi) nas estações de verão e inverno.

21 Quociente metabólico ( $\mu \mathrm{g} \mathrm{CO}_{2} / \mu \mathrm{g} \mathrm{C} \mathrm{g}^{-1}$ solo $\mathrm{h}^{-1}$ ) nos ecossistemas do PETAR: Mata Natural do PETAR (MNP), Mata Natural da Barra do Chapéu (MNBC) e Mata Plantada do PETAR (MPP) nas estações de verão e inverno.... 55 
22 Quociente metabólico ( $\mu \mathrm{g} \mathrm{CO}_{2} / \mu \mathrm{g} \mathrm{C} \mathrm{g} \mathrm{g}^{-1}$ solo $\mathrm{h}^{-1}$ ) nos ecossistemas do PECJ: Mata Natural de Campos do Jordão (MNCJ), Mata Plantada de Campos do Jordão (MPCJ) e Mata Plantada de Campos do Jordão com ocorrência de incêndio (MPCJi) nas estações de verão e inverno............................................... 56

23 Atividade da enzima urease ( $\mu \mathrm{g} \mathrm{N}-\mathrm{NH}_{4}{ }^{+} \mathrm{g}^{-1}$ solo $\mathrm{h}^{-1}$ ) nos ecossistemas do PETAR: Mata Natural do PETAR (MNP), Mata Natural da Barra do Chapéu (MNBC) e Mata Plantada do PETAR (MPP) nas estações de verão e inverno...

24 Atividade da enzima urease ( $\mu \mathrm{g} \mathrm{N}-\mathrm{NH}_{4}{ }^{+} \mathrm{g}^{-1}$ solo $\mathrm{h}^{-1}$ ) nos ecossistemas matas do PECJ: Mata Natural de Campos do Jordão (MNCJ), Mata Plantada de Campos do Jordão (MPCJ) e Mata Plantada de Campos do Jordão com ocorrência de incêndio (MPCJi) nas estações de verão e inverno

25 Hidrólise do diacetato de fluoresceína (FDA) (mg fluoresceína $\mathrm{g}^{-1}$ solo dia $^{-1}$ ) nos ecossistemas do PETAR: Mata Natural do PETAR (MNP), Mata Natural da Barra do Chapéu (MNBC) e Mata Plantada do PETAR (MPP) nas estações de verão e inverno.

26 Hidrólise do diacetato de fluoresceína (FDA) (mg fluoresceína $\mathrm{g}^{-1}$ solo dia $^{1}$ ) nos ecossistemas matas do PECJ: Mata Natural de Campos do Jordão (MNCJ), Mata Plantada de Campos do Jordão (MPCJ) e Mata Plantada de Campos do Jordão com ocorrência de incêndio (MPCJi) nas estações de verão e inverno....

27 Atividade da enzima $\beta$-glicosidase ( $\rho$-nitrofenol $\mathrm{g}^{-1}$ solo $\mathrm{h}^{-1}$ ) nos ecossistemas do PETAR: Mata Natural do PETAR (MNP), Mata Natural da Barra do Chapéu (MNBC) e Mata Plantada do PETAR (MPP) nas estações de verão e inverno.

28 Atividade da enzima $\beta$-glicosidase ( $\rho$-nitrofenol $\mathrm{g}^{-1}$ solo $\mathrm{h}^{-1}$ ) nos ecossistemas do PECJ: Mata Natural de Campos do Jordão (MNCJ), Mata Plantada de Campos do Jordão (MPCJ) e Mata Plantada de Campos do Jordão com ocorrência de incêndio (MPCJi) nas estações de verão e inverno 


\section{LISTA DE TABELAS}

Página

1 Localização das árvores utilizadas no presente estudo...................................... 20

2 Dados de temperatura máxima e mínima $\left({ }^{\circ} \mathrm{C}\right)$ e de precipitação total (mm) referentes aos meses de coleta no PETAR...................................................... 21

3 Localização das árvores utilizadas no presente estudo...................................... 25

4 Dados de temperatura máxima e mínima $\left({ }^{\circ} \mathrm{C}\right)$ e de precipitação total $(\mathrm{mm})$ referentes aos meses de coleta no PECJ.............................................................

5 Resumo das áreas estudadas e suas siglas ...................................................... 26

6 Resultado da análise granulométrica realizada na profundidade de 0-10 cm nos solos sob as matas avaliadas........................................................................ 41

7 Atributos químicos dos solos avaliados na profundidade de $0-10 \mathrm{~cm}$ sob as matas do PETAR: Mata Natural do PETAR (MNP), Mata Natural da Barra do Chapéu (MNBC) e Mata Plantada do PETAR (MPP).

8 Atributos químicos dos solos avaliados na profundidade de $0-10 \mathrm{~cm}$ sob as matas do PECJ: Mata Natural de Campos do Jordão (MNCJ), Mata Plantada de Campos do Jordão (MPCJ) e Mata Plantada de Campos do Jordão com ocorrência de incêndio (MPCJi). 


\section{ATRIBUTOS BIOQUÍMICOS COMO INDICADORES DA QUALIDADE DE SOLO EM FLORESTAS DE Araucaria angustifolia (Bert.) O. Ktze. NO ESTADO DE SÃO PAULO}

Autora: FERNANDA DE CARVALHO

Orientadora: Prof ${ }^{\mathrm{a}}$. Dra ${ }^{\mathrm{a}}$. ELKE JURANDY BRAN NOGUEIRA CARDOSO

\section{RESUMO}

Araucaria angustifolia, espécie brasileira considerada a mais explorada devido à qualidade de sua madeira, encontra-se na atualidade ameaçada de extinção. Diante deste fato a preservação dos remanescentes torna-se ainda mais importante, considerando que a extinção de uma única espécie pode comprometer todo um ecossistema. O objetivo deste estudo foi verificar a utilização dos atributos bioquímicos como indicadores de qualidade do solo em seis ecossistemas de araucária. Os atributos bioquímicos considerados foram carbono e nitrogênio da biomassa microbiana, respiração basal, quociente metabólico, e atividade das enzimas $\beta$-glicosidase, urease e hidrólise do diacetato de fluoresceína (FDA) Os ecossistemas avaliados foram mata com araucária (nativa, nativa com interferência antrópica e reflorestamento) em dois parques estaduais (PECJ e PETAR), localizados em duas diferentes regiões do Estado de São Paulo, Campos do Jordão e Apiaí, respectivamente. Foram selecionadas cinco árvores de araucária por ecossistema, onde, sob a copa de cada uma foram retiradas três amostras de solo na profundidade de 0-10 cm, totalizando quinze amostras por ecossistema. Foram realizadas quatro coletas em estações contrastantes, no inverno de 2002 e 2003 e no verão de 2003 e 2004. Os valores isolados de carbono e nitrogênio da biomassa microbiana, não serviram como indicadores precisos e confiáveis da qualidade do solo 
quanto os demais parâmetros avaliados. Os atributos bioquímicos que denotam processos edáficos dos ecossistemas (respiração basal, quociente metabólico, FDA e a atividade das enzimas urease e $\beta$-glicosidase) mostraram-se mais sensíveis para captar as alterações ocorridas no ambiente, e os valores encontrados para estes atributos sugerem que os ecossistemas avaliados sejam sustentáveis, onde a cobertura vegetal e rizosfera seriam importantes para a manutenção de sua funcionalidade. 


\section{BIOCHEMICHAL ATTRIBUTES AS SOIL QUALITY INDICATOR IN Araucaria angustifolia (Bert.). Ktze. FORESTS IN THE STATE OF SÃO PAULO}

Author: FERNANDA DE CARVALHO Adviser: Prof. Dr. ELKE JURANDY BRAN NOGUEIRA CARDOSO

\section{SUMMARY}

Brazil Pine (Araucaria angustifolia) has been the most explored Brazilian tree species due to its high quality wood and nowadays it is endangered of extinction. Therefore the preservation of the remainders becomes even more important, considering that the extinction of one species could endanger the whole ecosystem. The objective of this study was to evaluate the use of biochemichal soil attributes as soil quality indicators in six Brazil Pine ecosystems. The following biochemichal attributes were evaluated: carbon and nitrogen of the microbial biomass, soil respiration, the metabolic quotient, fluorescein diacetate (FDA) hydrolysis and the activities of $\beta$-glicosidase and urease. The different Brazil Pine ecosystems that were considered, consisted of native forests, replanted areas, impacted area in the two state parks (PECJ and PETAR), located in two different regions of the State of São Paulo-Brazil, Campos do Jordão and Apiaí, respectively. Five Pine trees for each ecosystems were selected and three $0-10 \mathrm{~cm}$ deep soil samples were collected under the crown of each tree, totalizing fifteen samples. The samplings were carried out in the winter of 2002 and 2003 and in the summer of 2003 and 2004. The carbon and nitrogen microbial biomass by themselves were less sensitive than other attributes as indicators of soil quality. Parameters related to soil processes in the ecosystems (soil respiration, metabolic quotient, FDA hydrolysis and the enzymatic activity of urease and $\beta$-glicosidase were more responsive to 
environmental disturbance. Nevertheless, these parameters suggest that all evaluated the ecosystems are sustainable, and that the vegetation (rhizosphere) is very important for maintenance of its functionality. 


\section{INTRODUÇÃO}

A Araucaria angustifolia, conhecida simplesmente como araucária, é uma conífera típica da América do Sul (Azevedo, 1994). No Brasil, segundo Mattos (1972), a araucária é encontrada nos planaltos, a uma altura de 600-800 m e em casos isolados, acima de 1000m, principalmente nos Estados do Rio Grande do Sul, Santa Catarina, Paraná e São Paulo. Nos Estados do Rio de Janeiro e Minas Gerais encontram-se apenas algumas áreas isoladas ocupadas por esta espécie. A excelente qualidade e ampla utilização de sua madeira fizeram com que a araucária se tornasse uma das espécies nativas mais exploradas no Brasil. Está presente na lista oficial de espécies da flora brasileira ameaçadas de extinção, sendo classificada pelo IBAMA como vulnerável (BRASIL, 1992) e em perigo de extinção num futuro próximo, se os fatores causais continuarem operando (Maior, 1997). Por isso mesmo, o reflorestamento e a manutenção das poucas matas que ainda existem são de suma importância no âmbito da biodiversidade ecológica, assim como no econômico.

Poucas pesquisas envolvendo a araucária têm sido feitas no Brasil e no mundo, a maioria destas direcionada à produção e manejo ecológico (Schneider et al. 1992) e poucas relacionadas a microrganismos do solo e seus processos, limitando as informações necessárias para o sucesso de reflorestamento e/ou, manutenção da sustentabilidade das florestas existentes. Os processos bioquímicos são fundamentais ao funcionamento de todos os ecossistemas terrestres, pois todos os membros da cadeia alimentar são dependentes do solo como fontes de nutrientes, degradação e ciclagem de matéria orgânica e fluxo de energia por diversos níveis tróficos (Dick, 1994). 
Compreendendo os processos biológicos do solo com a utilização de indicadores de estresse do ecossistema, poder-se-iam antecipar as estratégias e metodologias a serem aplicadas, visando promover a sua sustentabilidade.

A biomassa microbiana do solo, graças à sua atividade, atua na formação e na estabilização de agregados (Gupta \& Germida, 1998) e na ciclagem de nutrientes, além de ser considerada bioindicadora da qualidade do solo (Angers et al., 1993). O tamanho da comunidade microbiana e a sua atividade determinam a intensidade com que os processos bioquímicos acontecem. Sua avaliação dá indicações sobre ciclagem da matéria orgânica, podendo atuar como fonte e dreno de nutrientes, através dos processos de mineralização e imobilização. A atividade e a biomassa microbiana, por sua vez, são influenciadas, entre outros fatores, por temperatura, umidade, aeração e disponibilidade de substratos no solo (Cattelan \& Vidor, 1990). A vegetação influencia diretamente a biomassa microbiana e, por isto, a sua eliminação ocasiona uma drástica queda da biomassa de carbono, como revelam estudos envolvendo desmatamentos (Campos, 1998, Cerri et al., 1985 e Pfenning et al., 1992;). Segundo estes pesquisadores, a redução está relacionada a modificações da estrutura do solo, bem como à quantidade e qualidade da matéria orgânica do solo, que sofre nítida modificação com a substituição da mata nativa por outros sistemas.

Como a vegetação e seus efeitos sobre o solo se alteram com a idade do ecossistema, parâmetros microbiológicos e bioquímicos do solo poderão se constituir em bons indicadores da funcionalidade dos ecossistemas. A vegetação exuberante do ecossistema mata induz maiores modificações no solo que a campestre, alterando a produção e distribuição, bem como a dinâmica de transformação microbiana dos resíduos orgânicos depositados (Ryan \& Mcgarity, 1983 e Siqueira et al., 1994). Em solos sob mata, as perdas de nutrientes do ecossistema são menores em relação àqueles sob campo, em conseqüência da maior diversidade florística, da melhor cobertura do solo durante o ano e da maior imobilização no solo. Por outro lado, as gramíneas 
apresentam um efeito rizosférico intenso em virtude do seu abundante sistema radicular, o que geralmente promove elevada taxa de reciclagem (Rovira, 1978).

A fertilidade natural do solo depende, portanto, da dinâmica da matéria orgânica e ciclagem de nutrientes, as quais são catalisadas pela biomassa microbiana do solo (Alcântara, 1995). As propriedades biológicas e bioquímicas do solo, tais como: biomassa microbiana, atividade enzimática e taxa de respiração são indicadores sensíveis que podem ser utilizados no monitoramento de alterações ambientais, sendo ferramentas para orientar o planejamento e a avaliação das práticas de manejo utilizadas. Avaliações destas propriedades, embora críticas para o entendimento do ecossistema, podem não refletir alterações na estrutura das comunidades microbianas, devido à elevada redundância fisiológica a as complexas relações entre comunidades particulares (Kennedy \& Smith, 1995). Os processos de mineralização do C e N orgânicos, por exemplo, apresentam alto grau de redundância, isto é, diferentes populações de microrganismos podem, em diferentes condições ambientais, realizar esses processos. Atividades apresentando alto grau de redundância dificilmente se correlacionam com alterações da qualidade do solo, embora esses parâmetros sejam úteis na determinação das taxas de degradação de materiais orgânicos no solo (Brookes, 1995).

Stenberg (1999) enfatiza que nenhum indicador individualmente conseguirá descrever e quantificar todos os aspectos da qualidade do solo. Nem mesmo uma única função do solo é suficiente, já que deve haver uma relação entre todos os seus atributos. Assim, um número mínimo de indicadores deve ser selecionado. O critério para a seleção de indicadores relaciona-se, principalmente, com a utilidade em definir os processos do ecossistema. Estes integram as propriedades físicas, químicas e biológicas, além da sensibilidade a fatores como manejo, poluição e variações climáticas (Doran, 1997). 


\subsection{Objetivos Gerais}

Este trabalho teve como objetivo geral verificar a possível utilização de atributos bioquímicos como indicadores de qualidade do solo em remanescentes de mata com araucária no Estado de São Paulo, em diferentes condições de preservação e de interferência antrópica.

\subsection{Objetivos específicos}

Avaliar seis ecossistemas remanescentes com araucária no Estado de São Paulo através dos atributos bioquímicos, tais como:

Carbono e nitrogênio na biomassa microbiana;

Respiração Basal;

Quociente Metabólico;

Hidrólise do diacetato de fluoresceína;

Atividade da urease;

Atividade da $\beta$-glicosidase.

Caracterizar o solo através de análises química e física a fim de relacionar tais propriedades aos atributos bioquímicos. 


\section{REVISÃO DE LITERATURA}

\subsection{Araucaria angustifolia (Bertoloni) Otto Kuntze}

“Assim, a Araucária angustifolia, com seus ramos voltados para cima, parece clamar por uma
coexistência harmônica, brindando o homem com sua rara beleza, suas deliciosas
e nutritivas sementes e também com sua valiosa madeira”
(Solórzono Filho \&Kraus, 1999)

Pertencente a família das Araucariaceae a Araucaria angustifolia, no passado batizada pelos índios brasileiros de curii, cori, curi e curiúva, hoje é chamada de pinheiro-do-paraná, pinheiro-brasileiro, ou simplesmente araucária (Simões \& Lino, 2002). É caracterizada por ser uma árvore dióica, possuindo o desenvolvimento de suas sementes a partir de óvulos nus, sem a presença de ovários, o que inclui esta espécie dentro da divisão das Gymnospermas (Solórzano \& Kraus, 1999).

A araucária é uma espécie perenifólia, heliófita pioneira, típica de regiões de altitude, possui tronco reto, uniforme e cilíndrico, sua altura varia de 30 a 50 metros e o diâmetro do tronco, à altura do peito $(130 \mathrm{~cm})$ da planta adulta, pode alcançar desde pouco mais de um metro até dois metros e meio. As folhas são duras e pontiagudas, possuem até seis centímetros de comprimento e $10 \mathrm{~mm}$ de espessura, sendo presas diretamente aos ramos da planta (Lorenzi, 1992).

Devido às diferenças existentes no formato das copas da araucária, é possível distinguir uma araucária jovem de uma adulta, sendo que nos indivíduos jovens a copa apresenta-se na forma de cone, e nos adultos a copa é sempre alta (acima de 20m), 
possuindo forma de guarda chuva e, à medida que vai se tornando senil, a copa adquire a forma de taça. A araucária pode ter sua idade calculada através dos anéis de crescimento formados no tronco, podendo alcançar em torno de 200 a 300 anos (Solórzano Filho \& Kraus, 1999).

Todas as espécies do gênero Araucaria encontram-se no hemisfério sul e evoluíram na Era Mesozóica, durante os períodos Jurássico e Cretáceo, há aproximadamente 250 milhões de anos (Koch \& Corrêa, 2002).

Sua ocorrência limita-se entre as latitudes de $15^{\circ}$ e $30^{\circ} \mathrm{S}$ e longitudes de $43^{\circ}$ 30’ e $57^{\circ}$ 30’ W (Hueck, 1972).

Golfari (1967) situa a área de ocorrência natural em clima temperado, em que a temperatura média anual varia de 13 a $18^{\circ} \mathrm{C}$, caracterizando-se por verões frescos e invernos relativamente frios até $-8^{\circ} \mathrm{C}$. Van Goor (1965) diz que os tipos climáticos de Köppen, Cwb, Cfb e Cfa, caracterizados por apresentarem chuvas bem distribuídas durante o ano, não são limitantes, porém altitudes abaixo de 600 metros são consideradas críticas para a espécie.

Até o início do século XX, a Araucaria angustifolia dominava as paisagens no sul do Brasil, onde cobria boa parte do Planalto Meridional (Koch \& Corrêa, 2002). Ocupava originalmente cerca de 20 milhões de hectares (Reitz et al. 1983), distribuídos nos estados do Paraná (40\%), Santa Catarina (31\%) e Rio Grande do Sul (25\%) e como manchas esparsas no sul de São Paulo (3\%), internando-se até o sul de Minas Gerais e Rio de Janeiro, em áreas de altitude elevada (1\%) (Mattos, 1972).

Originalmente as araucárias no Estado de São Paulo têm sua zona de ocorrência nas regiões de maior altitude alcançando cerca de 1700m (Campos do Jordão), prevalecendo nos municípios do sul (onde está limitada pela divisa com o Paraná, de Itacaré para leste até cerca de Apiaí) e sudeste do Estado, nas Serras de Paranapiacaba, Mantiqueira, incluindo-se a Cantareira e aparecendo no Vale do Paraíba (Lobo, 2003 e Mattos, 1994).

Segundo os últimos resultados do Atlas da Evolução dos Remanescentes Florestais e dos Ecossistemas Associados à Mata Atlântica, desenvolvido pela fundação 
SOS Mata Atlântica e pelo Instituto de Pesquisas Espaciais, entre 1985 a 1995 o Estado de São Paulo, a araucária está condenada ao desaparecimento pelo diminuto número de exemplares atualmente existentes (Lobo, 2003).

A exploração da araucária no Estado acelerou-se a partir da década de trinta, tendo um ciclo de aproximadamente quarenta anos, período esse suficiente para dizimar cerca de cinqüenta mil hectares, em função da qualidade da madeira comercialmente conhecida como pinho (Lobo, 2003). As utilizações mais comuns da araucária estiveram associadas à obtenção de madeira para tabuados, vigamentos, pranchões, caixas, móveis, cabos de vassoura e ferramentas, palitos de dente e de fósforo, fabricação de compensados, pasta mecânica e celulose, matéria plástica, lã e seda artificiais, instrumentos musicais, tacos de nó, mourões, telhas de tabuinhas etc. Os galhos e refugos, e especialmente o nó, servem para lenha e combustível de caldeiras, e os pinhões servem de alimento para o homem e para os animais (Lorenzi, 1992).

A araucária serviu a toda uma geração que, assim como aconteceu com outros recursos naturais renováveis, não se preocupou em repô-lo e conservá-lo. No âmbito florestal, a extinção de uma única espécie pode comprometer todo um ecossistema, condenando sua existência (Lobo, 2003). Nesse sentido, é tarefa primordial reverter o atual quadro de desolação frente às florestas com araucária no Estado de São Paulo para uma situação que garanta a conservação do remanescente e crie condições para sua recomposição.

O presente trabalho está vinculado ao programa BIOTA-FAPESP com o subprojeto intitulado "Biodiversidade Vegetal e de Organismos Edáficos em Ecossistemas de Araucaria angustifolia Naturais e Impactados no Estado de São Paulo” sob a coordenação da Professora Doutora Elke J. B. N. Cardoso, que tem como objetivo comum estudar a biodiversidade do Estado de São Paulo, visando: a) compreender os processos geradores e mantedores da biodiversidade, incluindo também aqueles que possam resultar em sua redução deletéria; b) sistematizar a coleta de informações relevantes para a tomada de decisões sobre as prioridades de conservação e o uso sustentável da biodiversidade; c) divulgar toda a informação gerada de maneira ampla, 
rápida e livre; d) melhorar a qualidade do ensino, em todos os níveis e formas, sobre a natureza e os princípios fundamentais da conservação e do uso sustentável da diversidade biológica.

Estão envolvidos no presente trabalho dois Parques Estaduais que tem como principal objetivo a preservação dos remanescentes florestais. O primeiro é o Parque Estadual Turístico do Alto do Ribeira (PETAR), situado no município de Apiaí, que foi criado em 1958, sendo um dos Parques mais antigos do Estado de São Paulo. Sua área de 35.880 hectares abriga o valioso patrimônio natural da Região do Alto Ribeira, composto por sítios paleontológicos, arqueológicos e históricos, além da grande diversidade biológica característica da Mata Atlântica preservada em toda sua extensão. O PETAR está localizado no sudeste do Estado de São Paulo, nos municípios de Iporanga (76\%) e Apiaí (24\%), compreendendo as encostas da Serra de Paranapiacaba,

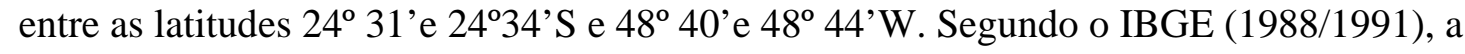
região se enquadra na Reserva da Biosfera da Mata Atlântica, sua vegetação é classificada como Floresta ombrófila higrófila densa, com formações aluviais (Floresta ciliar), sub montanas (abaixo de 400m) e montanas (entre 400 e 1000m).

Pela classificação de Köeppen, os subgrupos climáticos são Cfa e Cfb, que são subtropicais úmidos, sem estação seca, com verão quente e fresco, respectivamente.

Quanto ao aspecto sócio econômico, existem cerca de 100 famílias morando no interior do Parque, realizando agricultura de subsistência, extração ilegal de palmito (Euterpe edulis), lenha, caça ilegal e atividades ligadas ao ecoturismo.

O segundo é o Parque Estadual de Campos do Jordão (PECJ), situado no município de Campos do Jordão, criado em 1941 com o objetivo de resguardar os últimos remanescentes das florestas de araucária da região. Sua área de 8.172 hectares está localizada na Serra da Mantiqueira ao norte do município de Campos do Jordão,

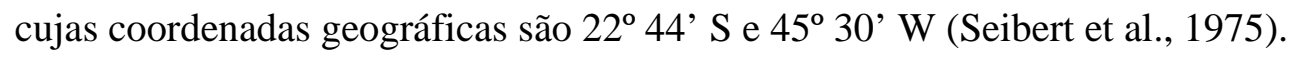

Seu relevo é montanhoso, apresentando declives acentuados. Em geral, as encostas apresentam declives superiores a 45\%, atingindo com freqüência valores de $60 \%$ e até $100 \%$ (Seibert et al., 1975). 
Três tipos principais de cobertura vegetal estão representados no Parque Estadual de Campos do Jordão: Campos Altimontanos, Mata mista de Podocarpus e Araucaria e Mata subtropical úmida de encosta. De acordo com a classificação de Köppen, o clima é do tipo Cfb, ou seja: clima subtropical da altitude, mesotérmico e úmido, sem estiagem (Seibert et al., 1975).

Quanto ao aspecto sócio econômico, a principal atividade do PECJ é o turismo ecológico, onde são recebidos por ano cerca de cem mil visitantes em suas áreas de recreação e lazer, além de manter uma programação de atividades que estimulam a pesquisa, a educação ambiental e a conservação dos recursos naturais.

\subsection{Qualidade do solo}

“O solo é uma sepultura no seu mais amplo sentido, e ainda assim ele é a verdadeira mola mestra de nova vida Se algum objeto pode demonstrar a possibilidade de ressurreição, este objeto é o solo sobre o qual caminhamos. Igualmente fascinante é que ele não é uma massa inerte, mas o cenário de infinitas preparações e transformações, realizadas, não apenas pela ação química, mas pelos organismos vivos” (Wrightson \& Newsham, 1919, citado por Lynch, 1986)

Tendo como objetivo avaliar a qualidade do solo, faz-se necessário buscar algumas definições sobre esse conceito.

A qualidade do solo refere-se à capacidade deste em sustentar a produtividade biológica dentro das fronteiras do ecossistema, mantendo o equilíbrio ambiental e promovendo a saúde de plantas e animais e do próprio ser humano (Doran et al., 1996 e Sposito \& Zabel, 2003).

O termo “saúde do solo”, usado como sinônimo de qualidade do solo, é preferido por alguns, por retratar o solo como um sistema vivo e dinâmico, cujas funções são 
mediadas por uma diversidade de organismos que requerem práticas próprias de manejo e conservação.

As práticas e manejos inadequados têm levado os solos do mundo todo à degradação e conseqüentemente à perda de qualidade. Portanto, a perda da qualidade do solo, além de um componente a ele inerente, determinado por suas propriedades físicas, químicas e biológicas, dentro das restrições impostas pelo clima e o ecossistema, inclui um componente determinado pelas decisões de uso da terra (tipo de exploração) e práticas de manejo (modo de exploração) (Doran, 2000).

De acordo com Dumanski \& Pieri (2000), a base científica que respalda a busca por indicadores de qualidade do solo é a compreensão de que esses indicadores estão direcionados para a avaliação e/ou o monitoramento das condições do solo que o tornam um corpo vivo. De outra forma, esses indicadores específicos desta escala devem ter a capacidade e a sensibilidade para medir e avaliar atributos e processos do solo que interfiram na promoção da sua vida. Karlen et al. (1994) explicam que as práticas de manejo que adicionam ou mantêm carbono orgânico no solo parecem estar entre as mais importantes para restabelecer, manter ou melhorar a qualidade do solo. Essa explicação é bastante norteadora para a busca de indicadores de qualidade do solo, pois mostra que os atributos candidatos a indicadores que têm íntima relação com a matéria orgânica têm maior chance de serem adequados para o objetivo em questão.

O entendimento do solo como um corpo vivo significa considerar que todos os seus processos e componentes estão funcionalmente bem integrados. Portanto, a vida do solo e os seus processos vitais são expressos e regulados pela biota do solo. Essa regulação da biota sobre a decomposição de resíduos orgânicos, ciclagem de nutrientes, degradação de poluentes químicos e a sua forte influência sobre a estrutura do solo, faz com que esses microrganismos e esses processos sejam naturalmente escolhidos como indicadores da saúde ou qualidade do solo (Jenkinson \& Ladd, 1981, Kennedy, 1998 e Lynch, 1986). 
As populações microbianas do solo sofrem acentuada influência do ambiente, podendo os microrganismos ou seus processos ser inibidos em até $100 \%$ por diversos fatores estressantes. Devido à elevada diversidade fisiológica, ecológica e funcional, as populações podem se recuperar do impacto.

Influências antropogênicas podem alterar a diversidade e a funcionalidade dos microrganismos que são altamente sensíveis a distúrbios, afetando a estabilidade e a resiliência do solo (Kennedy, 1998 e Reber, 1992). A relação entre diversidade microbiana e qualidade do solo tem sido muito discutida, mas não foi ainda completamente definida. O tempo necessário para o ecossistema retornar ao seu estado inicial, após um distúrbio qualquer, define a resiliência do sistema. Quanto maior esse tempo, menor a resiliência. Se a diversidade das comunidades microbianas do solo está diretamente relacionada com sua resiliência, ainda não está definido. No entanto, esta é uma hipótese plausível, se considerarmos que a diminuição de diversidade pode resultar em diminuição da redundância de funções bioquímicas e conseqüentemente redução da diversidade metabólica (Reber, 1992).

A orientação dessa pesquisa coloca uma questão chave que deve ser respondida pelo estudo dos indicadores envolvidos no presente trabalho:

Os atributos bioquímicos avaliados podem ser considerados como indicadores de qualidade do solo? Se sim, qual ou quais?

\subsection{Importância da matéria orgânica no solo e suas transformações.}

Como já descrito anteriormente, a matéria orgânica do solo (MOS) tem íntima relação com os candidatos a indicadores da qualidade do solo.

O acúmulo de matéria orgânica no solo tem como principal responsável a deposição de materiais orgânicos no solo provenientes da vegetação, formando o que chamamos de serapilheira. Das variáveis climáticas, a precipitação e a temperatura são as que exercem maior influência na formação da serapilheira. Portanto pode se concluir que o tipo de vegetação e as condições ambientais são fatores determinantes da 
quantidade e qualidade do material que cai no solo, determinando a heterogeneidade e a taxa de decomposição do material depositado na superfície (Correia \& Andrade, 1999 e Moreira \& Siqueira, 2002).

A decomposição de resíduos provenientes da fitomassa e zoomassa do solo constitui um processo biológico básico, no qual o carbono é reciclado para a atmosfera na forma de $\mathrm{CO}_{2}$, o nitrogênio pode se tornar disponível como $\mathrm{NH}_{4}{ }^{+}$e $\mathrm{NO}_{3}{ }^{-}$e outros elementos, como $\mathrm{P}, \mathrm{S}$ e vários micronutrientes, podem se transformar em formas requeridas pelas plantas superiores. Nesse processo, parte dos nutrientes é assimilada e armazenada pelos microrganismos (Orjuela, 1989). Contudo, essa mineralização não é completa, e uma grande parte dos compostos orgânicos é modificada pelos microrganismos, formando complexos resistentes formadores da fração humificada do solo. Assim, pode-se considerar as seguintes etapas no processo de decomposição: lavagem de compostos hidrossolúveis e colonização microbiana; ataque da fauna do solo e de microrganismos, com fragmentação, transporte, mistura, e biodegradação do material e, por último, transformação húmica e mineral (Gonzalez \& Gallardo, 1982). Em outras palavras, a decomposição da matéria orgânica pode ser dividida em três processos básicos que ocorrem simultaneamente: lixiviação (retirada de material solúvel pela ação da água da chuva), intemperismo (ruptura mecânica dos detritos) e ação biológica (fragmentação gradual e oxidação dos detritos pelos organismos vivos); esses processos iniciam-se quando o tecido vegetal se forma e continuam por toda a sua vida (Haag, 1985).

A importância da MOS aumenta em ecossistemas de floresta tropical, que apresentam solos pobres em nutrientes e onde a vegetação depende em grande parte da reciclagem de nutrientes contidos nos detritos vegetais (Herrera et al., 1978).

A biomassa microbiana (BM) é a parte viva da matéria orgânica do solo e funcionalmente, atua como agente de transformação da matéria orgânica no ciclo de nutrientes e no fluxo de energia, representando um importante compartimento de armazenamento de carbono e nutrientes no solo de agroecossistemas (Jenkinson \& Ladd, 1981 e Wardle, 1992), sendo aproximadamente 1,4 e 2,8 \% do total mundial de C e N do 
solo, respectivamente, reciclando uma quantidade apreciável de carbono e nitrogênio (De-Polli \& Guerra, 1996 e Wardle,1992).

As bactérias e os fungos são responsáveis por cerca de $90 \%$ da atividade da BM (Siqueira, 1994). As bactérias do solo formam o grupo que apresenta maior abundância e diversidade entre as espécies, sua comunidade é estimada em cerca de $10^{8}$ a $10^{9}$ organismos por grama de solo. Este grupo apresenta alta capacidade de degradação dos diferentes substratos contidos no solo, exercendo importante papel na decomposição da matéria orgânica e na ciclagem de nutrientes. Os fungos são os principais contribuintes em peso para a BM do solo, são encontrados com comunidades variando de $10^{4}$ a $10^{6}$ organismos por grama de solo e podem ser responsabilizados por aproximadamente $70 \%$ da matéria seca (Brandão, 1992).

A biomassa microbiana é influenciada pelo teor de argila dos solos. A argila aumenta a adsorção de compostos orgânicos e nutrientes, proporciona maior capacidade tampão e protege os microrganismos contra predadores. Solos com altos teores de argila apresentam maior imobilização de $\mathrm{C}$ e $\mathrm{N}$ pela biomassa microbiana.

Considerando-se a hierarquia ecológica no sistema edáfico, descrito por Hattori \& Hattori, citado por Siqueira (1994), tem-se que os microrganismos mostram alterações ocorridas no ambiente antes mesmo que estas promovam alterações nas propriedades químicas e físicas do solo.

A avaliação da BM é útil para prover informações rápidas sobre mudanças nas propriedades orgânicas do solo, detectar mudanças causadas por cultivos ou devastação de florestas, ou determinar a regeneração de solos após a remoção da camada superficial e avaliar os efeitos da poluição com metais pesados e pesticidas (Powlson et al., 1987).

A respiração basal (RB) é definida como a respiração sem adição de substratos orgânicos ao solo, e pode ser avaliada através da produção de $\mathrm{CO}_{2}$ ou consumo de $\mathrm{O}_{2}$ (Alef, 1995). A respiração é o parâmetro mais antigo utilizado na quantificação da atividade metabólica nos solos. Assim como outras atividades metabólicas, a respiração é dependente do estado fisiológico da célula e influenciada por diversos fatores no solo, tais como umidade, temperatura, estrutura do solo e disponibilidade de nutrientes. 
A interpretação dos resultados da atividade biológica deve ser feita com critério, uma vez que elevados valores de respiração nem sempre indicam condições desejáveis: uma alta taxa de respiração pode significar, em curto prazo, liberação de nutrientes para as plantas e, em longo prazo, perda de carbono orgânico do solo para a atmosfera (Parkin et al.,1996). Anderson \& Domsch (1993) propuseram a determinação do quociente metabólico $\left(q \mathrm{CO}_{2}\right)$, que tem por definição a relação entre a quantidade de $\mathrm{CO}_{2}$ produzida por unidade de C da BM e por unidade de tempo, como componente relevante na avaliação dos efeitos ambientais e antropogênicos sobre a atividade microbiana do solo.

De acordo com Chander \& Brookes (1993) e Leita et al. (1995), um maior valor da respiração microbiana deve-se a uma maior reciclagem da comunidade microbiana, necessitando de um maior consumo de energia para a sua sobrevivência. A atividade biológica do solo transforma-o em um grande incinerador biológico, capaz de decompor, através da ação enzimática, os componentes da MOS e outros compostos orgânicos depositados no solo, resultando em compostos mais simples (Siqueira et al., 1994). As enzimas responsáveis por estas atividades podem ser intracelulares (no interior de organismos vivos ou mortos) ou extracelulares, podendo estas estar livres ou ligadas a colóides do solo (Lynch, 1986). As enzimas estão associadas à vida das células metabolicamente ativas. Portanto, as fontes de enzimas para o solo são os microrganismos, os vegetais e a fauna. Os microrganismos produzem enzimas extracelulares, responsáveis pela quebra de moléculas de elevado peso molecular, enzimas que, posteriormente, podem ficar na solução do solo. As enzimas também podem ser liberadas pela morte e lise celular dos microrganismos ou ainda por modificação da permeabilidade celular (Burns, 1986).

Enzimas recém produzidas extracelularmente por células vivas ou liberadas pela ruptura de células recém mortas normalmente têm altos níveis de atividade no solo. Na ausência de novas sínteses, as concentrações destas enzimas podem diminuir rapidamente, devido à vulnerabilidade a hidrólises por proteinases microbianas ou 
reações com argila e colóides do solo. Estas enzimas, quando associadas a humatos do solo mantêm sua atividade por períodos longos (Burns, 1978, 1986).

De modo geral, o que se tem feito em termos de enzimologia do solo é a determinação da atividade e dos fatores que sobre ela podem influir. Para tal, aplica-se um inibidor da atividade microbiana nas amostras de solo, de modo que se eliminem as complicações do crescimento microbiano como contribuinte para a atividade, avaliandose, em seguida, o desaparecimento do substrato ou aparecimento do produto (Lynch,1986).

Lynch (1986) descreve que, em algumas investigações, foi demonstrada uma nítida correlação entre os números de microrganismos e atividade enzimática, embora às vezes a atividade pareça ser independente da proliferação microbiana. Entretanto, números de microrganismos raramente se correlacionam com a biomassa microbiana, e tem havido poucos esforços no sentido de se tentar correlacionar a biomassa microbiana com atividade enzimática, pois é bastante claro que uma parte da atividade enzimática seja independente de células vivas, pois o tratamento de esterilização ou inibição dos microrganismos com agentes químicos (tolueno, óxido de etileno, fenol, acetona, timol, clorofórmio) e físicos (calor, radiação ionizante) geralmente destrói os microrganismos sem abolir a atividade enzimática.

Entre os fatores importantes na determinação da atividade de enzimas do solo estão o preparo das amostras e o armazenamento, uma vez que o manuseio e a secagem ao ar, podem alterar o número de microrganismos e a atividade enzimática, assim como o pH, temperatura, tempo de incubação e concentração do substrato (Melo, 1988).

Existe no solo uma variada gama de microrganismos com suas enzimas associadas e enzimas livres. As técnicas que nos permitem fazer avaliações quantitativas e qualitativas da biomassa microbiana dos solos e sua atividade possibilitarão a análise do significado dos microrganismos para os solos e vegetais. 


\section{MATERIAL E MÉTODOS}

\subsection{Descrição das áreas}

Como descrito antes, as áreas envolvidas no presente estudo são pertencentes a dois Parques Estaduais no Estado de São Paulo (Figura 1).

Foram estudadas no total seis áreas, sendo três delas em cada Parque, em diferentes tipos de conservação.

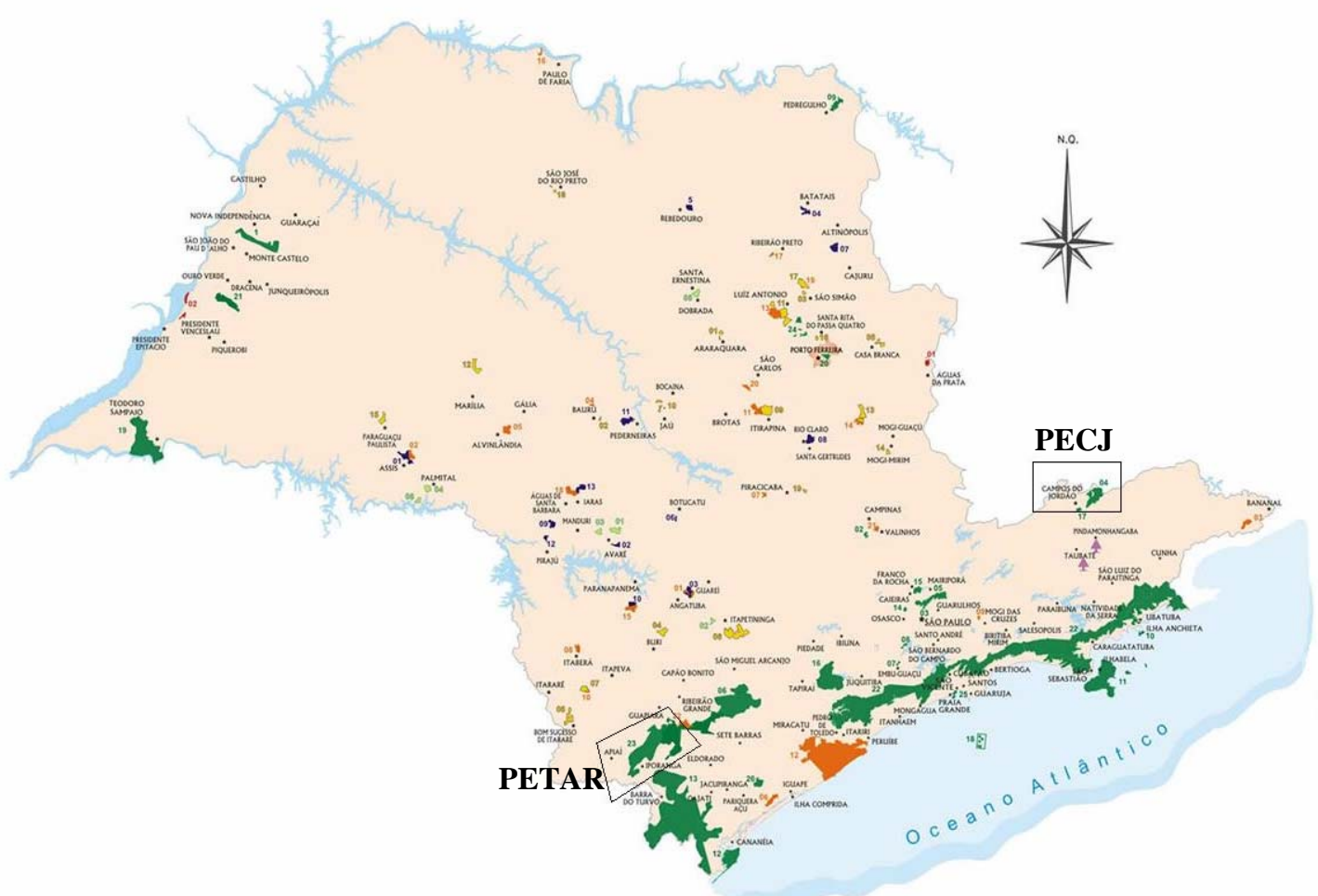

Figura 1 - Localização dos Parques Estaduais dentro do Estado de São Paulo

Fonte: (modificado de http://www.iflorestsp.br/) 


\subsection{1 Áreas do Parque Estadual Turístico do Alto do Ribeira - PETAR}

A primeira área de estudo é uma Mata Nativa e está situada na parte central do Parque próximo ao Núcleo dos Caboclos no município de Apiaí.

A mata bem fechada apresenta uma grande diversidade de espécies e, junto com as araucárias, estão presentes árvores centenárias como as canelas (Ocotea spp.; Nectandra spp.), cedros (Cedrella fissilis), figueiras (Ficus spp), jatobás (Hymenaea courbaril), bucuvas (Virola oleifera), palmito-juçara (Euterpe edulis), além de epífitas (bromélias, orquídeas e lianas) (Figura 2).

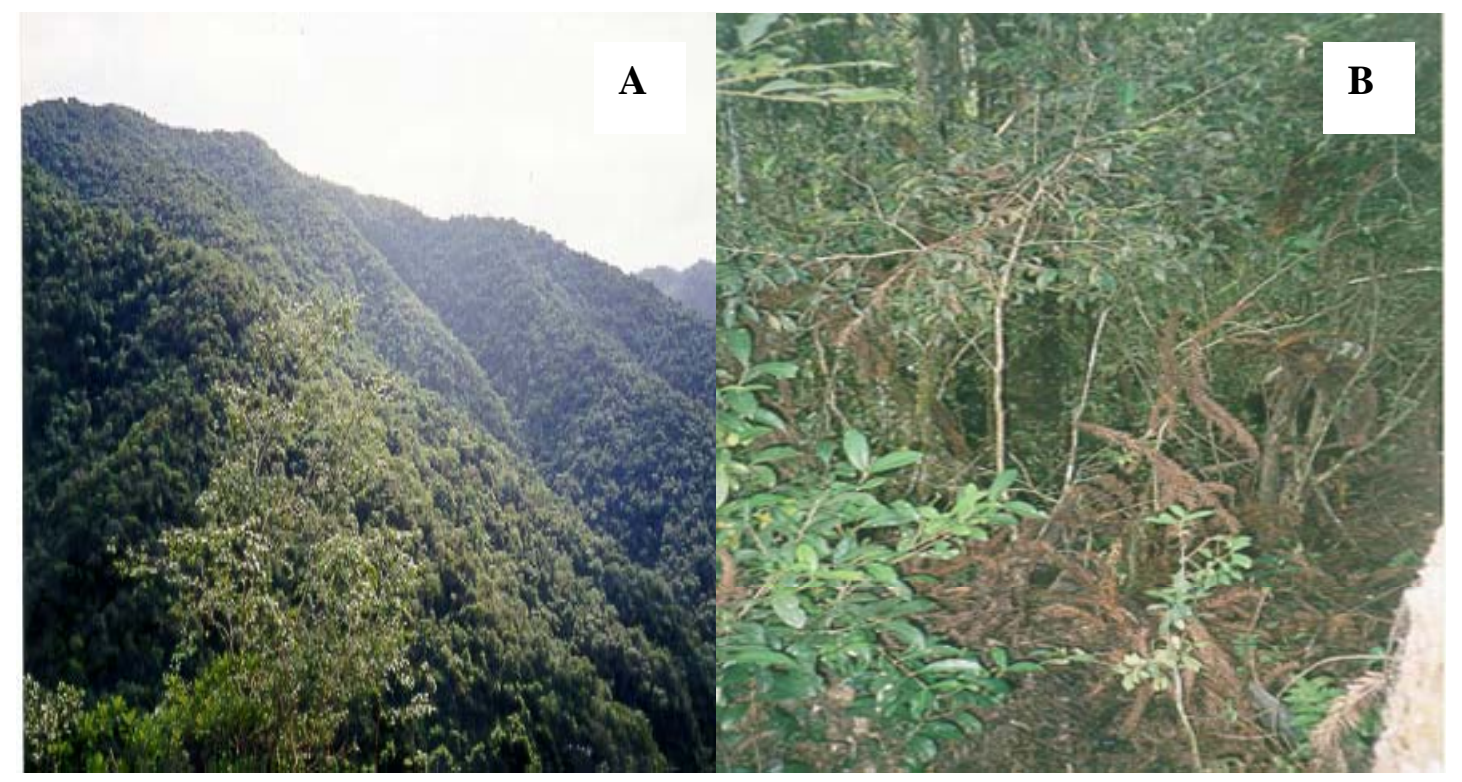

Figura 2 - A - Aspecto geral da Mata Nativa do PETAR (MNP)

B - Aspecto da cobertura do solo na Mata Nativa do PETAR (MNP)

A segunda área, localizada no município de Iporanga, antigamente usada para o plantio de tomates, hoje apresenta um plantio de araucárias com aproximadamente 18 anos. Há influência antrópica através de uma pequena agricultura de subsistência e alguns tipos de animais, como cavalos e gado. Esta área apresenta em seu sub-bosque restos de pastagem e um grande número de pequenas quaresmeiras (Tibouchina granulosa), típicas de formações secundárias (Lorenzi, 1992) (Figura 3). 


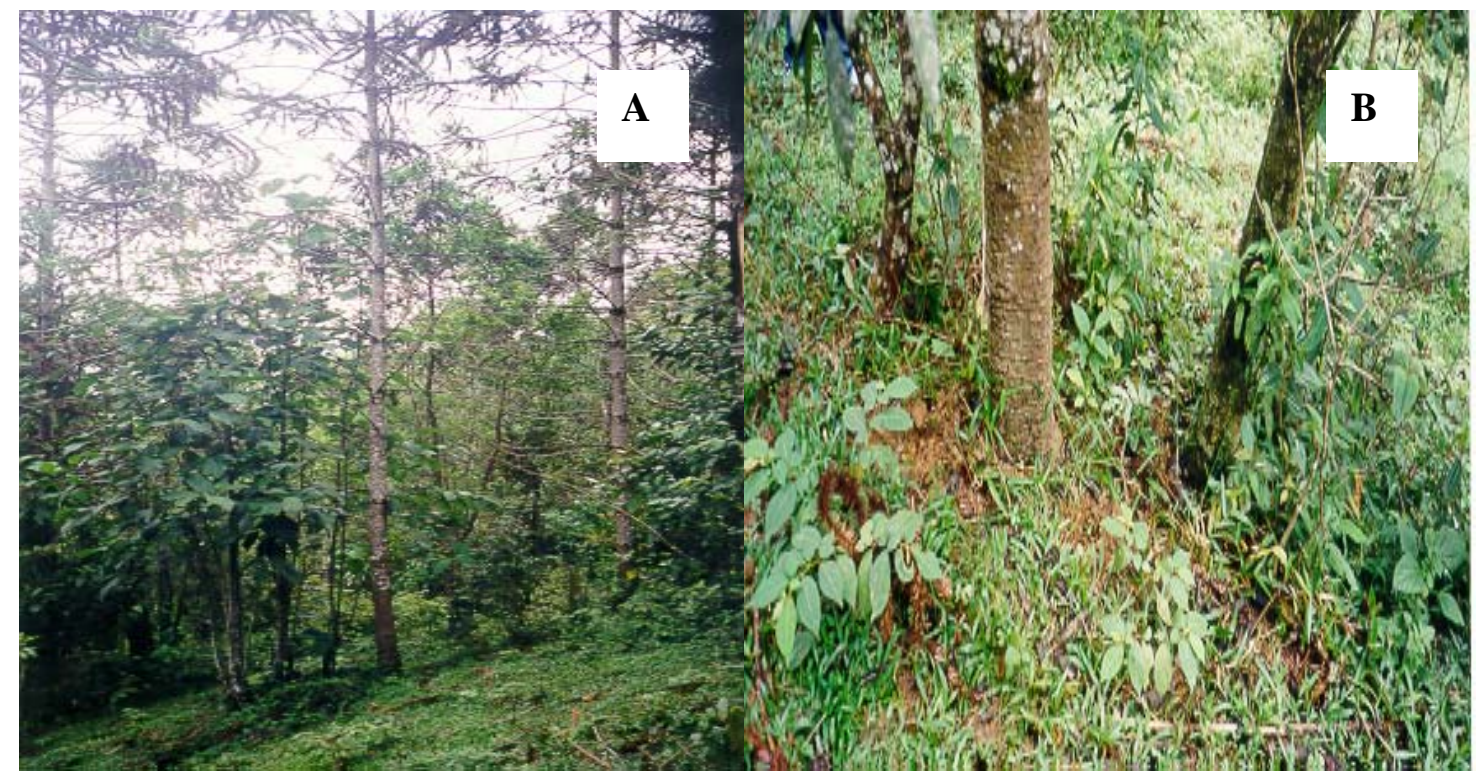

Figura 3 - A -Aspecto geral da Mata Plantada do PETAR (MPP)

B - Aspecto da cobertura do solo na Mata Plantada do PETAR (MPP)

A terceira área não é pertencente ao PETAR, porém faz fronteira com o Parque e está localizada no município de Barra do Chapéu, cujas coordenadas geográficas são $24^{\circ}$ 28' 23 S de latidude e 49 01' 28'” W de longitude, compreendendo uma área de 408,16 $\mathrm{Km}^{2}$ (Figura 4). Esta mata é predominada por araucárias, porém sofre uma intensa interferência antrópica, pois está próxima ao centro do município.

Há presença de agricultura de subsistência circundando a mata, assim como a entrada de pessoas e animais também é freqüente. Foi observada a presença de epífitas (bromélias e orquídeas), samambaias, jerivá (Syagrus romanzoffiana), carqueja (Baccharis trimera) e, apesar da intensa colheita dos pinhões, foi observada a regeneração da araucária.

Na terceira coleta ocorrida em setembro/2003, pode-se observar que houvera a ocorrência de um incêndio recente de baixa intensidade na área onde se concentravam as árvores do presente estudo, afetando o extrato inferior da mata (Figura 5). 


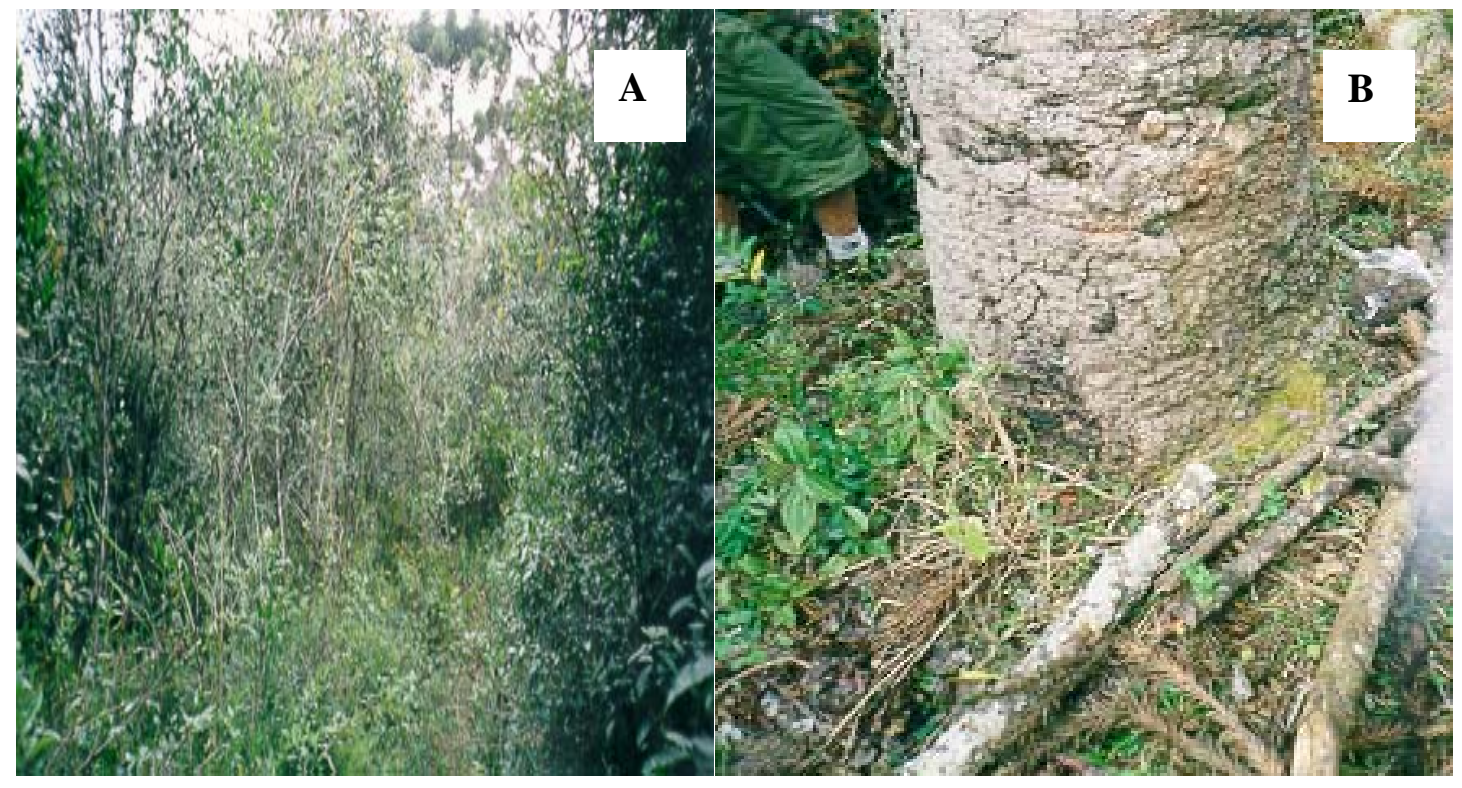

Figura 4 - A - Aspecto geral da Mata Natural da Barra do Chapéu (MNBC)

B - Aspecto da cobertura do solo na Mata Natural da Barra do Chapéu (MNBC)

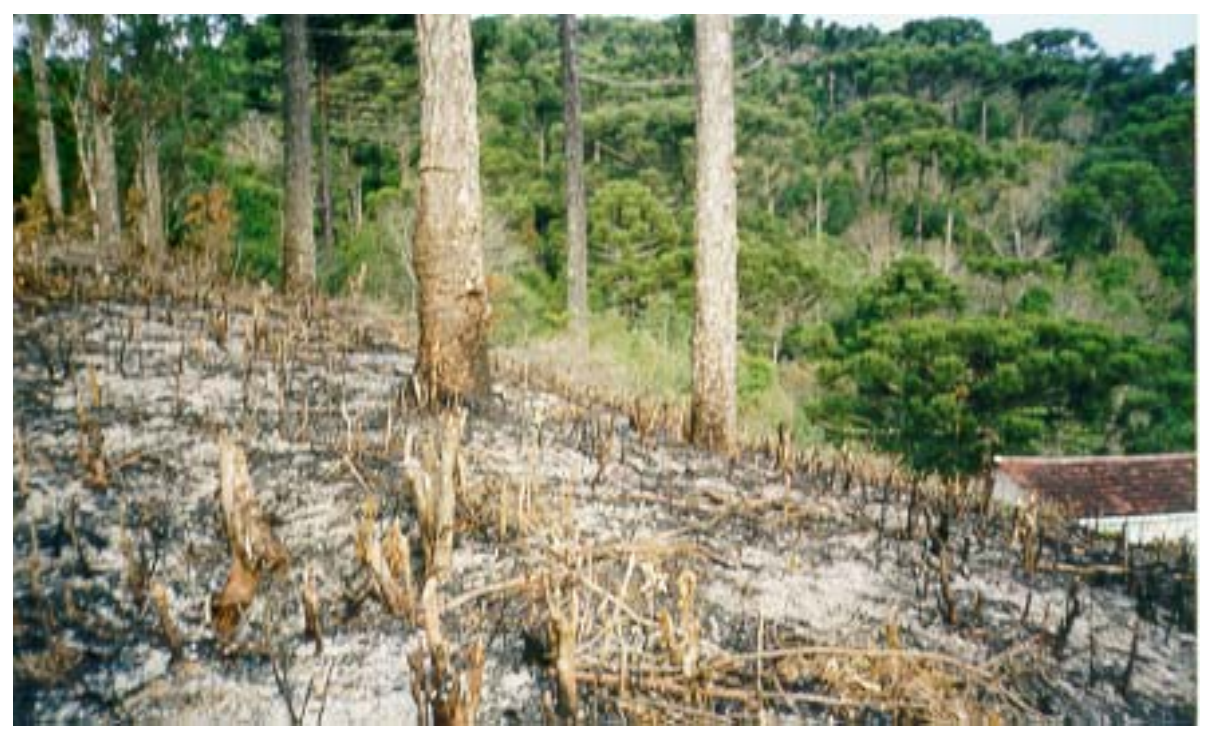

Figura 5 - Ocorrência de fogo recente, porém de baixa intensidade, na estação seca, na Mata Natural da Barra do Chapéu (MNBC) 
As árvores foram georreferenciadas usando um GPS MAGELAN 300 e os pontos em questão estão na Tabela 1.

Tabela 1. Localização das árvores utilizadas no presente estudo

\begin{tabular}{|c|c|c|c|}
\hline ÁREAS & ÁRVORES & LATITUDE & LONGITUDE \\
\hline MNP & \multicolumn{3}{|c|}{ Devido à mata muito fechada, a obtenção dos pontos não foi possível } \\
\hline MNBC & 1 & $24^{\circ} 28^{\prime} 27^{\prime \prime} \mathrm{S}$ & $49^{\circ} 01^{\prime} 17^{\prime \prime}$ W \\
\hline \multirow[t]{4}{*}{ Altitude: $831 \mathrm{~m}$} & 2 & $24^{\circ} 28^{\prime} 27^{\prime \prime} \mathrm{S}$ & $49^{\circ} 01^{\prime} 15^{\prime \prime} \mathrm{W}$ \\
\hline & 3 & $24^{\circ} 28^{\prime} 28^{\prime \prime} \mathrm{S}$ & $49^{\circ} 01^{\prime} 11^{\prime \prime} \mathrm{W}$ \\
\hline & 4 & $24^{\circ} 28^{\prime} 29^{\prime \prime} \mathrm{S}$ & $49^{\circ} 01^{\prime} 10^{\prime \prime} \mathrm{W}$ \\
\hline & 5 & $24^{\circ} 28^{\prime} 28^{\prime \prime} \mathrm{S}$ & $49^{\circ} 01^{\prime} 09^{\prime \prime} \mathrm{W}$ \\
\hline MPP & 1 & $24^{\circ} 20^{\prime} 13^{\prime \prime} \mathrm{S}$ & $48^{\circ} 36^{\prime} 15^{\prime \prime} \mathrm{W}$ \\
\hline \multirow[t]{4}{*}{ Altitude: 855 m } & 2 & $24^{\circ} 20^{\prime} 12^{\prime \prime} \mathrm{S}$ & $48^{\circ} 36^{\prime} 13^{\prime \prime} \mathrm{W}$ \\
\hline & 3 & $24^{\circ} 20^{\prime} 13^{\prime \prime} \mathrm{S}$ & $48^{\circ} 36^{\prime} 14^{\prime \prime} \mathrm{W}$ \\
\hline & 4 & $24^{\circ} 20^{\prime} 13^{\prime \prime} \mathrm{S}$ & $48^{\circ} 36^{\prime} 15^{\prime \prime} \mathrm{W}$ \\
\hline & 5 & $24^{\circ} 20^{\prime} 13^{\prime \prime} \mathrm{S}$ & $48^{\circ} 36^{\prime} 13^{\prime \prime} \mathrm{W}$ \\
\hline
\end{tabular}

O clima da região, como descrito anteriormente, é classificado por Köppen como Cfb. Os dados obtidos através da Estação meteorológica de Capão Bonito (temperatura) e do Posto pluviométrico de Apiaí (precipitação), referentes ao período de dois anos de coleta mostram que não houve mudanças bruscas de temperatura, apresentando médias anuais de 21,1, 20,1 e 19,7 ${ }^{\circ} \mathrm{C}$ nos anos de 2002, 2003 e 2004, respectivamente, e a precipitação apresentou-se bem distribuída ao longo dos anos, sem períodos de estiagem mas com período menos chuvoso ocorrendo de maio a agosto e o mais chuvoso ocorrendo de outubro a março (Figura 6). Os dados climáticos referentes aos meses de coleta são apresentados na Tabela 2. 


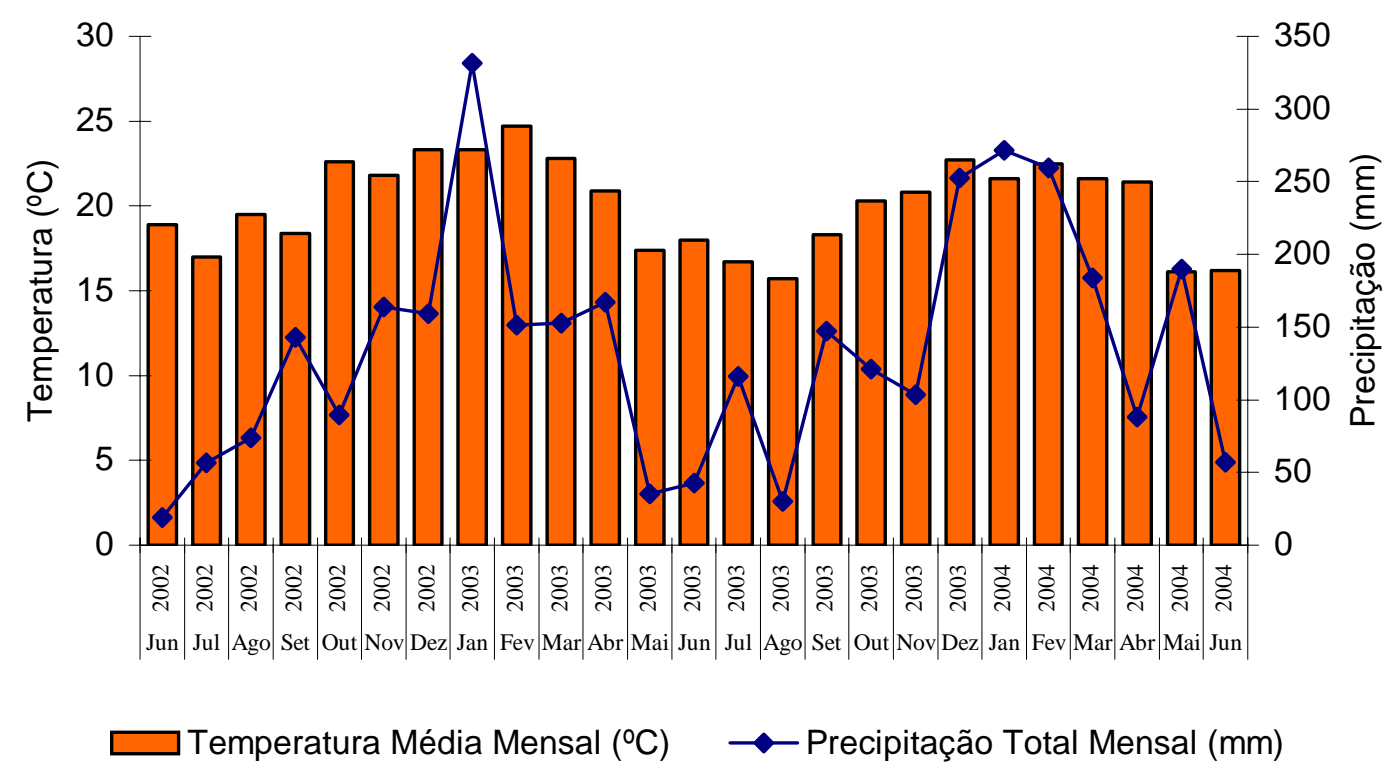

Figura 6 - Diagrama climático referentes as áreas estudadas no PETAR

Tabela 2. Dados de temperatura máxima e mínima $\left({ }^{\circ} \mathrm{C}\right)$ e de precipitação total $(\mathrm{mm})$ referentes aos meses de coleta no PETAR

\begin{tabular}{ccccc}
\hline Período & $\mathbf{T}^{\mathbf{0}} \mathbf{C}$ máxima & $\mathbf{T}^{\mathbf{0}} \mathbf{C}$ mínima & $\mathbf{T}^{\mathbf{0}} \mathbf{C}$ média & $\begin{array}{c}\text { Precipitação } \\
(\mathbf{m m})\end{array}$ \\
\hline Set./2002 & 24,4 & 12,1 & 18,2 & 142,9 \\
Jan./2003 & 27,6 & 18,9 & 23,2 & 331,6 \\
Set/2003 & 24,0 & 12,7 & 18,3 & 147,2 \\
Jan./2004 & 25,1 & 17,5 & 21,3 & 271,6
\end{tabular}

Fonte: DAEE - BRB - Posto pluviométrico de Apiaí (precipitação) e Estação meteorológica de Capão Bonito (temperaturas)

\subsection{2 Áreas do Parque Estadual de Campos do Jordão - PECJ}

Para o presente trabalho foram escolhidas três áreas dentro do PECJ. A primeira área escolhida representa uma mata natural em bom estado de conservação sobre um Latossolo Vermelho-Amarelo distrófico câmbico textura argilosa A húmico com A proeminente $(44 \mathrm{~cm})$ sobreposto. 
Está situada próxima à trilha da cachoeira (cachoeira Galharada), e é a área que apresenta maior diversidade dentro das áreas avaliadas no PECJ. Dentre as espécies presentes além das araucárias, estão o vassourão (Clethra scabra Pers.), canela (Ocotea diospyrifolia), maçaranduba (Persea pyrifolia), pinho-bravo (Podocarpus lambertii), entre outras, além de epífitas.

A presença de trilhas na mata é quase nula, e não há indícios de que esta área seja visitada por turistas (Figura 7).

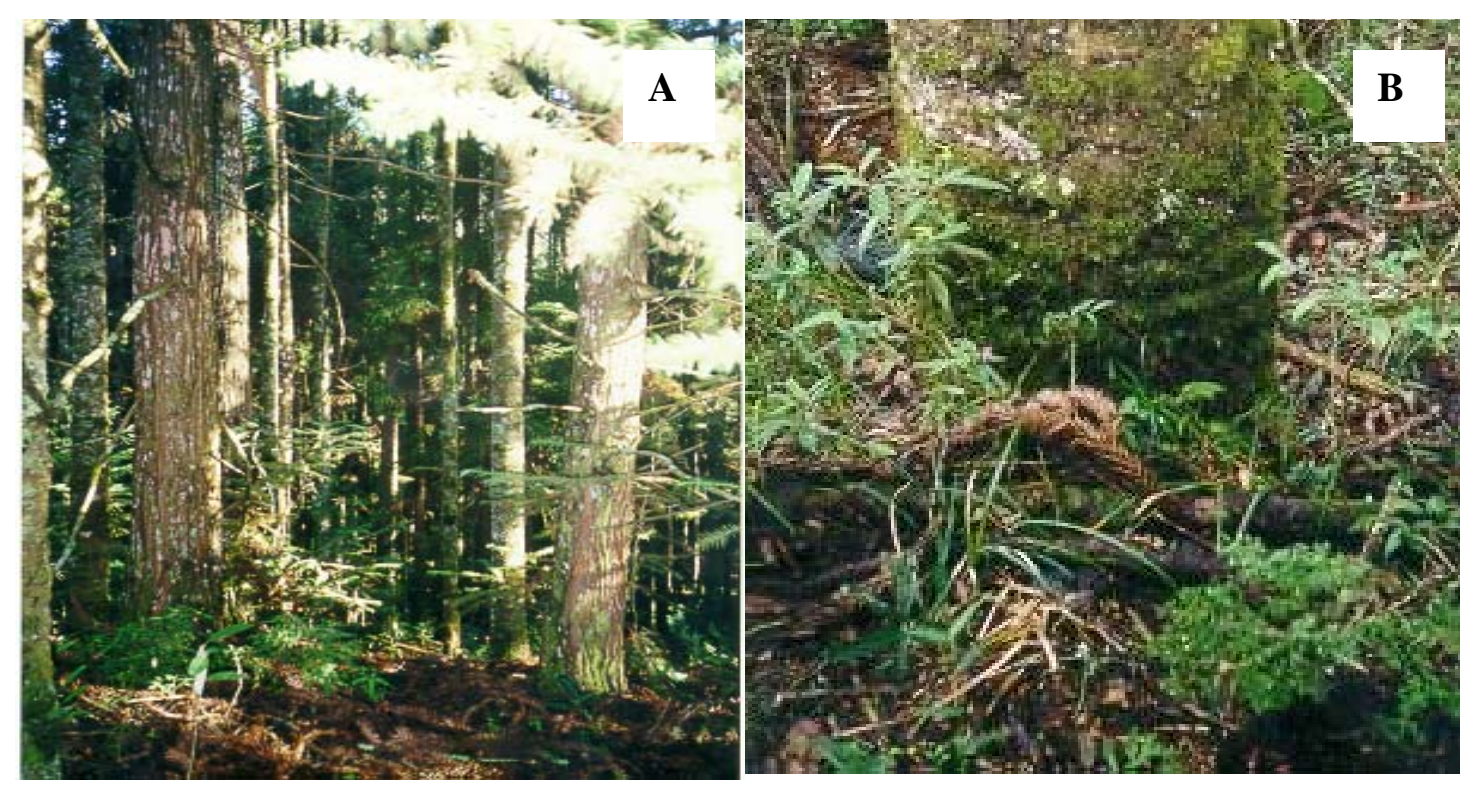

Figura 7 - A - Aspecto geral da Mata Nativa do PECJ (MNCJ)

B - Aspecto da cobertura do solo na Mata Nativa do PECJ (MNCJ)

As outras duas áreas escolhidas estão situadas próximas à estrada do Rio Sapucaí que liga o Parque ao Estado de Minas Gerais. Estas áreas foram plantadas com araucária, uma em 1958 e a outra em 1959.

O plantio de 1958 está situado sobre um Cambissolo Háplico Tb Distrófico latossólico textura argilosa A moderado. Possui araucárias de aproximadamente 45 anos, está situado próximo ao sítio denominado Pinho Bravo. O sub-bosque da mata é constituído principalmente por barba de bode (Aristidia longiseta) e carqueja (Baccharis 
trimera). É comum visualizar a presença de cavalos na área. Esta área também possui um histórico de incêndio em julho do ano de 2001(Figura 8).

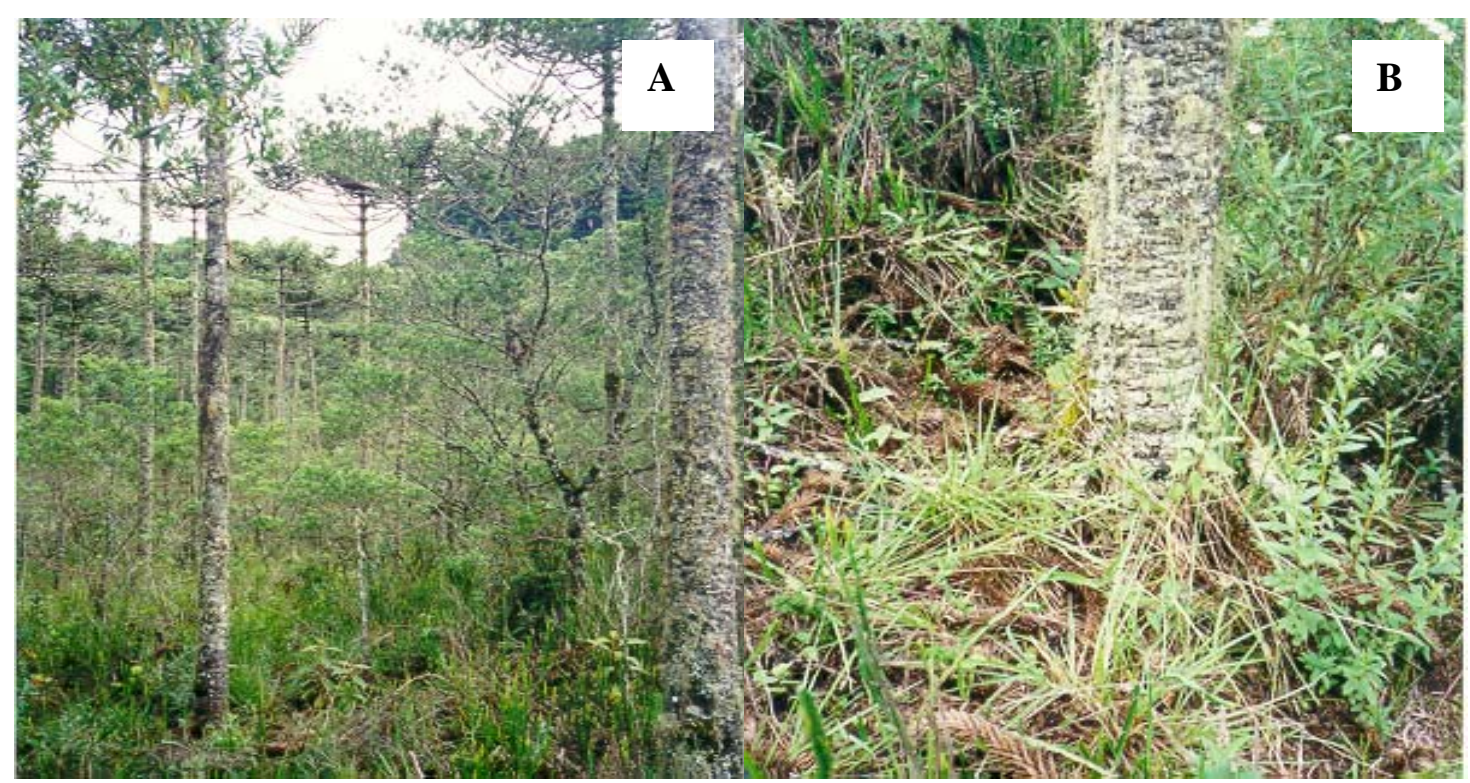

Figura 8 - A - Aspecto geral da Mata Plantada do PECJ com histórico de ocorrência de incêndio (MPCJi)

B - Aspecto do solo da Mata Plantada do PECJ com histórico de ocorrência de incêndio (MPCJi)

Vizinho de uma Mata Natural, o plantio de 1959 apesar de possuir praticamente com a mesma idade do anterior, apresenta maior diversidade florística e grande regeneração de araucárias. O solo sob esta mata é classificado como um Latossolo Amarelo distrófico câmbico textura argilosa A húmico com A proeminente $(28 \mathrm{~cm})$ sobreposto.

As espécies presentes em conjunto com a araucária são as mesmas pertencentes à mata natural, porém, com menor expressividade (Figura 9). 


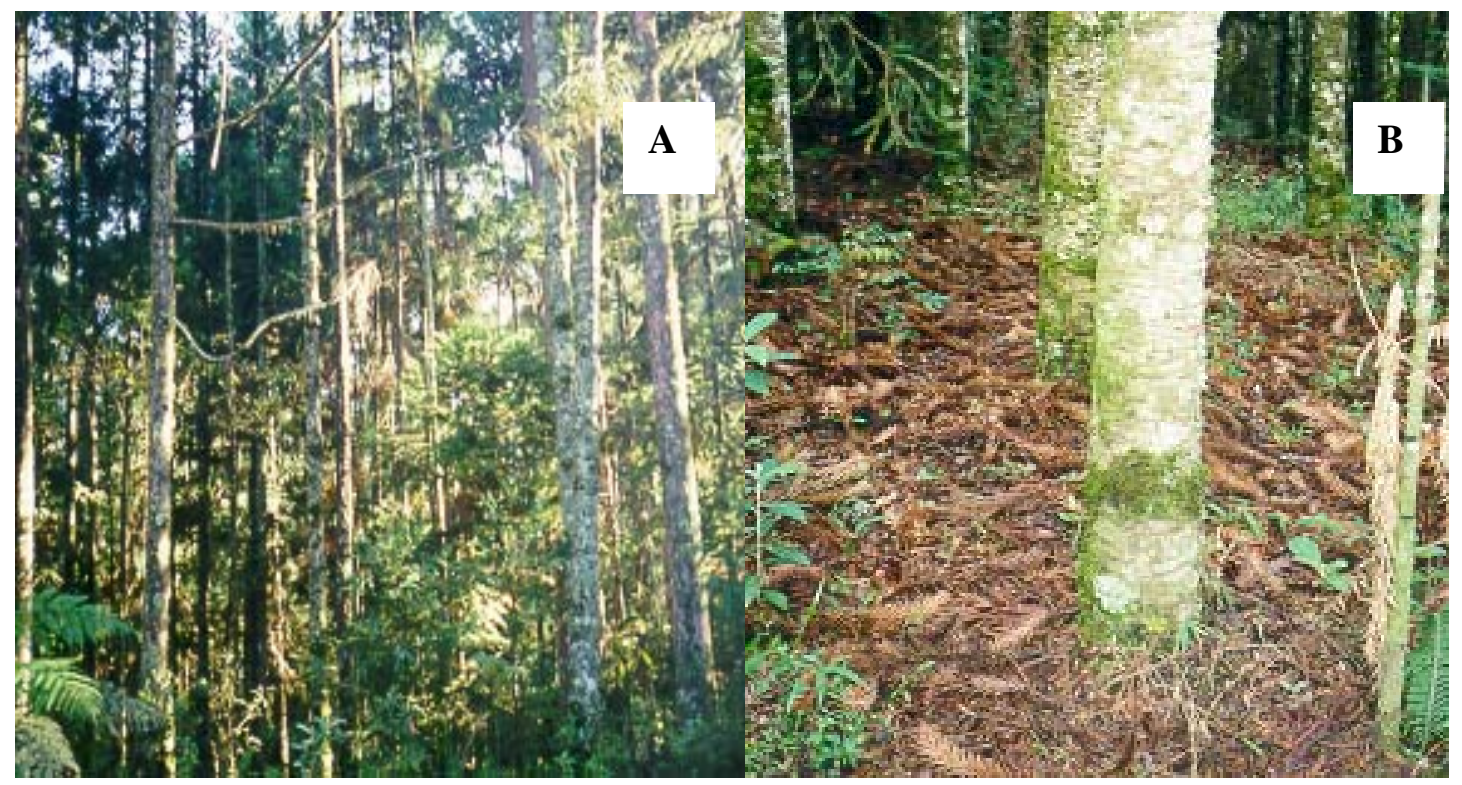

Figura 9 - A -Aspecto geral da Mata Plantada do PECJ (MPCJ)

B - Aspecto do solo da Mata Plantada do PECJ (MPCJ)

As árvores foram georreferenciadas usando um GPS MAGELAN 300, os pontos em questão estão na Tabela 3.

Os dados climáticos obtidos pela Estação meteorológica de Campos do Jordão mostram um período de estiagem juntamente com as menores temperaturas nos meses referentes ao inverno. Os meses referentes ao verão são os que apresentam maior volume de precipitação e as mais altas temperaturas (Figura 10).

Apesar da classificação climática do PECJ ser a mesma do PETAR (Cfb), verificou-se períodos de estiagem no inverno, assim como também médias de temperaturas mais baixas. Os dados climáticos referentes aos meses de coleta podem ser vistos na Tabela 4. 
Tabela 3. Localização das árvores utilizadas no presente estudo

\begin{tabular}{|c|c|c|c|}
\hline ÁREAS & ÁRVORES & LATITUDE & LONGITUDE \\
\hline \multirow[t]{5}{*}{ MNCJ } & 1 & $22^{\circ} 41^{\prime} 57^{\prime \prime} \mathrm{s}$ & $45^{\circ} 27^{\prime} 47^{\prime}, \mathrm{W}$ \\
\hline & 2 & $22^{\circ} 41^{\prime} 47^{\prime \prime} \mathrm{s}$ & $45^{\circ} 27^{\prime} 49^{\prime \prime} \mathrm{W}$ \\
\hline & 3 & $22^{\circ} 41^{\prime} 51^{\prime \prime} \mathrm{S}$ & $45^{\circ} 27^{\prime} 38^{\prime \prime} \mathrm{W}$ \\
\hline & 4 & $22^{\circ} 41^{\prime} 57^{\prime \prime} \mathrm{s}$ & $45^{\circ} 27^{\prime} 52^{\prime \prime \prime} \mathrm{W}$ \\
\hline & 5 & $22^{\circ} 41^{\prime} 45^{\prime \prime} \mathrm{s}$ & $45^{\circ} 27^{\prime} 58^{\prime \prime} \mathrm{W}$ \\
\hline \multirow[t]{5}{*}{ MPCJ } & 1 & $22^{\circ} 39^{\prime} 39^{\prime \prime} \mathrm{S}$ & $45^{\circ} 26^{\prime} 38^{\prime \prime} \mathrm{W}$ \\
\hline & 2 & $22^{\circ} 39^{\prime} 37^{\prime \prime} \mathrm{S}$ & $45^{\circ} 26^{\prime} 36^{\prime \prime} \mathrm{W}$ \\
\hline & 3 & $22^{\circ} 39^{\prime} 36^{\prime \prime} \mathrm{s}$ & $45^{\circ} 26^{\prime} 34^{\prime \prime} \mathrm{W}$ \\
\hline & 4 & $22^{\circ} 39^{\prime} 35^{\prime \prime} \mathrm{S}$ & $45^{\circ} 26^{\prime} 31^{\prime \prime} \mathrm{W}$ \\
\hline & 5 & $22^{\circ} 39^{\prime} 33^{\prime \prime} \mathrm{s}$ & $45^{\circ} 26^{\prime} 35^{\prime \prime} \mathrm{W}$ \\
\hline \multirow[t]{5}{*}{ MPCJi } & 1 & $22^{\circ} 40^{\prime} 07^{\prime \prime} \mathrm{S}$ & $45^{\circ} 27^{\prime} 42^{\prime \prime} \mathrm{W}$ \\
\hline & 2 & $22^{\circ} 40^{\prime} 05^{\prime \prime} \mathrm{S}$ & $45^{\circ} 27^{\prime} 39^{\prime \prime} \mathrm{W}$ \\
\hline & 3 & $22^{\circ} 40^{\prime} 06^{\prime \prime} \mathrm{S}$ & $45^{\circ} 27^{\prime} 43^{\prime \prime} \mathrm{W}$ \\
\hline & 4 & $22^{\circ} 40^{\prime} 08^{\prime \prime} \mathrm{S}$ & $45^{\circ} 27^{\prime} 54^{\prime \prime} \mathrm{W}$ \\
\hline & 5 & $22^{\circ} 40^{\prime} 07^{\prime \prime} \mathrm{S}$ & $45^{\circ} 27^{\prime} 43^{\prime \prime} \mathrm{W}$ \\
\hline
\end{tabular}

Tabela 4. Dados de temperatura máxima e mínima $\left({ }^{\circ} \mathrm{C}\right)$ e de precipitação total $(\mathrm{mm})$ referentes aos meses de coleta no PECJ

\begin{tabular}{ccccc}
\hline Período & $\mathbf{T}^{\mathbf{0}} \mathbf{C}$ máxima & $\mathbf{T}^{\mathbf{0}} \mathbf{C}$ mínima & $\mathbf{T}^{\mathbf{0}} \mathbf{C}$ média & $\begin{array}{c}\text { Precipitação } \\
\text { (mm) }\end{array}$ \\
\hline Out./2002 & 18,6 & 7,1 & 12,8 & 78,0 \\
Mar./2003 & 22,9 & 12,5 & 17,7 & 167,0 \\
Ago. /2003 & 12,6 & 4,3 & 8,45 & 8,9 \\
Fev. /2004 & 22,0 & 11,9 & 16,9 & 323,8 \\
\hline
\end{tabular}

Fonte: Estação meteorológica de Campos Jordão 


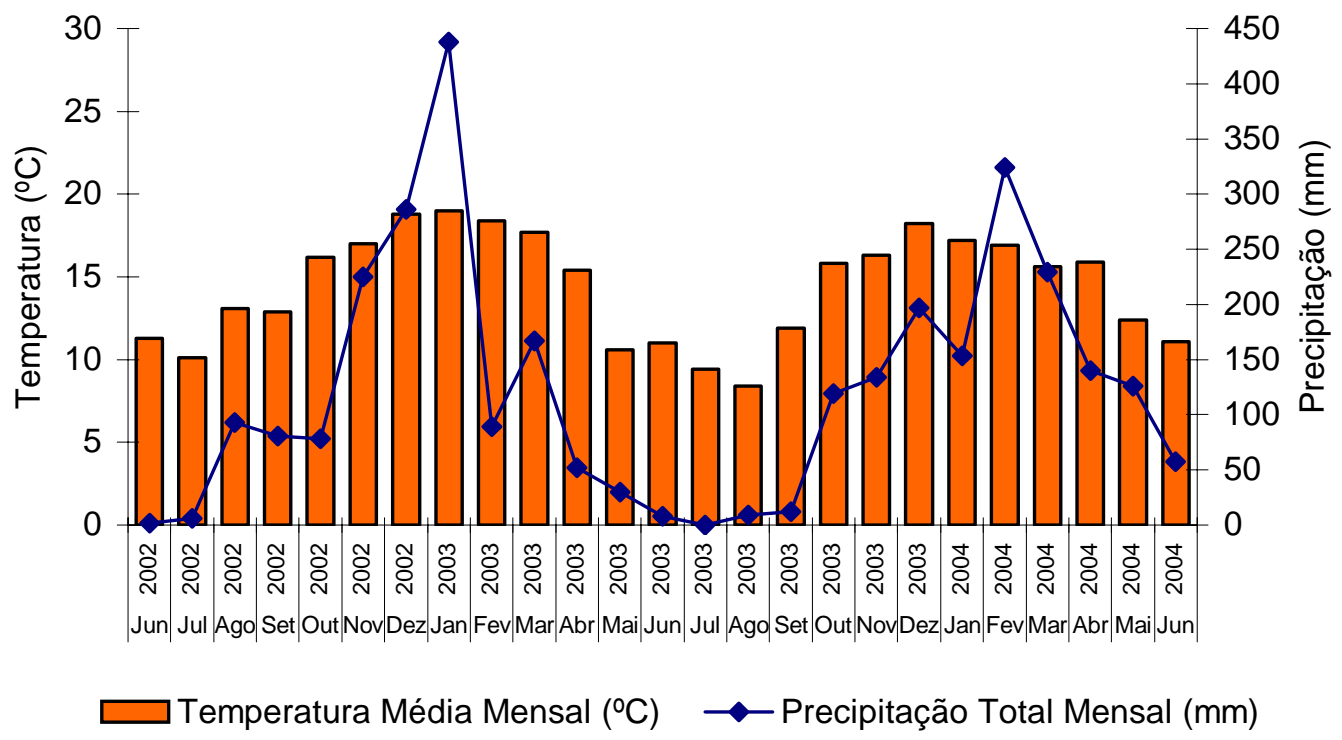

Figura 10 - Diagrama climático referente às áreas estudadas do PECJ

O resumo das áreas e suas siglas estão apresentados na Tabela 5.

Tabela 5. Resumo das áreas estudadas e suas siglas

\begin{tabular}{ccc}
\hline LOCALIDADE & TIPO DE MATA & SIGLAS \\
\hline PETAR & Mata Natural & MNP \\
PETAR & Mata Plantada (15 anos) & MPP \\
Barra do Chapéu & Mata Natural com ação antrópica & MNBC \\
PECJ & Mata Natural & MNCJ \\
PECJ & Mata Plantada (46 anos) \\
PECJ & $\begin{array}{c}\text { Mata Plantada (47 anos) com } \\
\text { histórico de incêndio }\end{array}$ & MPCJi \\
\hline
\end{tabular}




\subsection{Coleta das amostras}

Foram selecionadas cinco árvores de araucária por ecossistema analisado, onde, sob a copa de cada uma delas, foram retiradas três amostras de solo na profundidade de 0-10 cm, totalizando quinze amostras por ecossistema (Figura 11).

O solo coletado foi peneirando em malha $2 \mathrm{~mm}$ e armazenado em sacos plásticos em câmara fria.

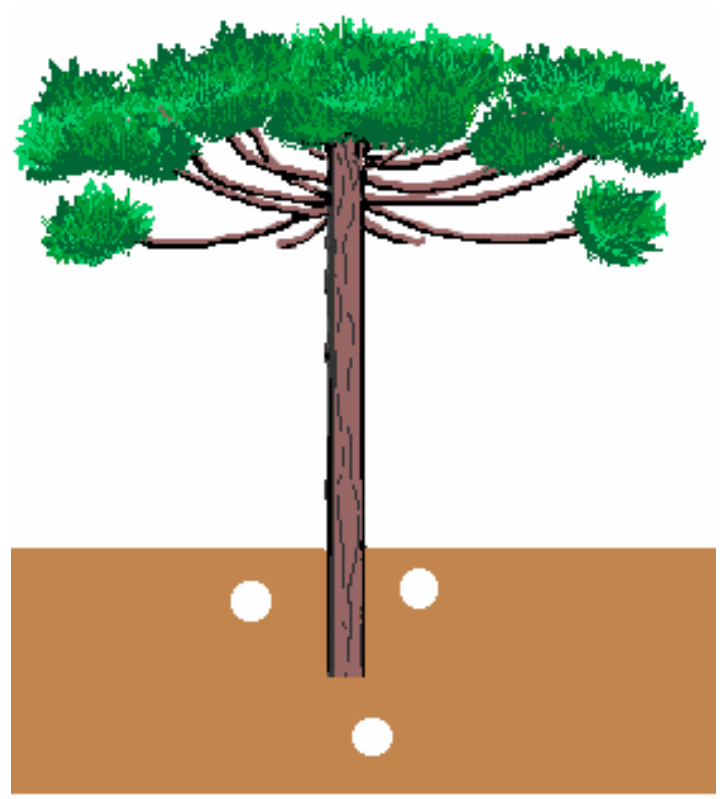

Figura 11 - Esquema dos três pontos de coleta sob a copa da araucária

\subsection{Análise granulométrica e avaliação dos atributos químicos}

Os três pontos coletados por árvore foram transformados em uma única amostra composta, totalizando cinco amostras compostas por área de estudo que posteriormente foram conduzidas ao Laboratório de Fertilidade e de Física do Solo da ESALQ/USP para a realização das análises.

Para a análise granulométrica foi utilizado o método do densímetro proposto por Camargo et al. (1986). 
A caracterização química do solo seguiu a metodologia descrita por Raij et al. (2001). O pH foi determinado em $5 \mathrm{ml}$ de solução $0,01 \mathrm{M} \mathrm{CaCl}_{2}$, para $\mathrm{H}+\mathrm{Al}$ foi utilizado o método de tampão SMP para determinação da acidez total. A matéria orgânica foi mensurada fotometricamente após digestão ácida de dicromato/sulfúrico. Cálcio, fósforo, magnésio e potássio foram extraídos com resina íon-trocável. O fósforo foi quantificado colorimetricamente usando amônio-molibdenio. Cálcio e magnésio foram determinados por espectrofotometria de absorção atômica e potássio por fotometria de chamas.

\subsubsection{Determinação do Carbono Total do solo}

O carbono total do solo (COT) foi estimado pelo método proposto por Raij et al. (2001).

O procedimento consiste em pesar $1 \mathrm{~g}$ da amostra de solo e transferi-la para um erlenmeyer de $500 \mathrm{~mL}$. Realizar uma prova em branco completa, sem terra. Essa indicação é para solos contendo entre 55 a $135 \mathrm{~g} \mathrm{dm}^{-3}$ de matéria orgânica. Adicionar 25 $\mathrm{mL}$ da solução de dicromato e $50 \mathrm{~mL}$ de $\mathrm{H}_{2} \mathrm{SO}_{4}$. Adicionar $400 \mathrm{~mL}$ de água destilada e filtrar, recebendo o filtrado em balão volumétrico de $500 \mathrm{~mL}$. Completar o volume e homogeneizar. Retirar uma alíquota de $200 \mathrm{~mL}$ e transferir para um erlenmeyer de 500 mL. Acrescentar $10 \mathrm{~mL}$ de $\mathrm{H}_{3} \mathrm{PO}_{4}$ concentrado p.a e 3 a 6 gotas da solução de difenilalanina. Titular com a solução de sulfato ferroso amoniacal, até a viragem de azul para verde. A titulação do branco serve para determinar a concentração exata de solução de sulfato ferroso amoniacal.

O carbono foi calculado pela expressão:

$$
\mathrm{C}=\left(\mathrm{V}_{\mathrm{br}}-\mathrm{V}_{\mathrm{am}}\right) * \mathrm{C}_{\mathrm{Fe}}^{2+} * 0,003 * 1,33 * 1000
$$

Onde:

$\mathbf{V}_{\mathbf{b r}}$ : volume de sulfato ferroso amoniacal, em $\mathrm{mL}$ gasto para titular o branco; 
$\mathbf{V}_{\mathbf{a m}}$ : volume de sulfato ferroso amoniacal, em mL gasto para titular a amostra;

$\mathbf{C}_{\mathbf{F e}}{ }^{2+}$ : concentração em mol $\mathrm{L}^{-1}$ de $\mathrm{Fe}^{2+}$ na solução padronizada de sulfato ferroso amoniacal, para a reação com o dicromato de potássio;

0,003: refere-se à razão $[(0.001 * 12) / 4]$, onde 12 é a massa molar do carbono $\left(\mathrm{g} \mathrm{mol}^{-1}\right)$, 0,001 é o fator para transformar em g mmol $^{-1}$ e 4 é o número de elétrons na oxidação da matéria orgânica (M.O);

1,33: é o fator de correção para a oxidação apenas parcial da M.O.

Os valores estão expressos em:

$$
\text { g C } \text { kg solo }^{-1}
$$

\subsubsection{Determinação do NitrogênioTotal do Solo}

O método proposto por Raij et al. (2001), onde o N orgânico é convertido em $\mathrm{NH}_{4}{ }^{+}$por digestão com $\mathrm{H}_{2} \mathrm{SO}_{4}$ em mistura com substâncias que agem como catalisadores ( $\mathrm{Cu}$ e $\mathrm{Se}$ ) ou que promovem a conversão e ajudam a manter alta temperatura durante a digestão $\left(\mathrm{K}_{2} \mathrm{SO}_{4}\right) . \mathrm{O} \mathrm{NH}_{4}^{+}$é, finalmente, determinado após destilação por arraste de vapor, adicionando-se solução concentrada de $\mathrm{NaOH}$ ao extrato de digestão.

O procedimento consiste em pesar uma amostra de solo contendo cerca de $1 \mathrm{mg}$ de N (0,5 a 1,0 g de solo). E transferir para um tubo de digestão. Incluir uma amostra padrão (branco) em cada conjunto de bloco digestor. A amostra deve ser moída para passar em peneira de 60 mesh $(250 \mu \mathrm{m})$.

Adicionar ao tubo de digestão $1 \mathrm{~g}$ da mistura digestora. Adicionar 3,0 $\mathrm{mL}$ de ácido sulfúrico concentrado. Colocar os tubos em bloco digestor e aquecê-lo 
cuidadosamente até a mistura parar de espumar. Cobrir os tubos com pequeno funil de vidro. Aumentar a temperatura até que o conteúdo do frasco fique claro e depois deixar em ebulição de modo que $\mathrm{H}_{2} \mathrm{SO}_{4}$ se condense a uma altura cerca de $1 / 3$ do tubo digestor. O funil visa garantir um refluxo eficiente do líquido durante a digestão e minimizar perdas do ácido. Remover os tubos do bloco digestor e deixá-lo esfriar à temperatura ambiente.

Fazer a destilação das amostras, e posteriormente titular o conteúdo do destilado com solução padronizada de $\mathrm{H}_{2} \mathrm{SO}_{4}$.

O nitrogênio foi calculado pela expressão:

$$
\left.\mathrm{N}\left(\mathrm{mg} \mathrm{kg}^{-1}\right)=\left(\left(\mathrm{V}_{\mathrm{am}}-\mathrm{V}_{\mathrm{br}}\right) * \mathrm{~F}_{\mathrm{ac}} * \mathrm{Vt} * 1000\right) / \mathrm{V}_{\text {dest }} * \mathrm{~m}_{\text {solo }}\right)
$$

Onde:

$\mathrm{V}_{\mathrm{am}}$ e $\mathrm{V}_{\mathrm{br}}$ : são os volumes de ácido sulfúrico em mL gastos na titulação das amostras e das provas em branco respectivamente;

$\mathrm{F}_{\mathrm{ac}}$ : é o fator do ácido sulfúrico, em $\mathrm{mg} \mathrm{N} \mathrm{mL}^{-1}$ de ácido;

Vt : é o volume em mL do extrato da digestão;

$\mathrm{V}_{\text {dest }}$ : é o volume em mL da alíquota do extrato destilado;

$\mathrm{m}_{\text {solo: }}$ é a massa do solo em g;

1000: é o fator para converter g para Kg.

Os valores estão expressos em:

g N kg solo ${ }^{-1}$ 


\subsection{Avaliação dos atributos bioquímicos}

\subsubsection{Carbono da biomassa microbiana}

O carbono da biomassa microbiana (CBM) foi determinado pelo método da fumigação-extração (Vance et al., 1987), com algumas modificações. Para cada ponto, foram pesadas duas amostras de $50 \mathrm{~g}$ cada, sendo uma amostra fumigada e a outra não fumigada que foi utilizada como controle. Para a fumigação utilizou-se um dessecador contendo um becker com pérolas de vidro e clorofórmio. O clorofórmio foi evaporado sob o vácuo. Após um período de 24 horas, procedeu-se a retirada do resíduo de clorofórmio do dessecador. Após a fumigação, ambas as amostras receberam então, 40 ml de $\mathrm{K}_{2} \mathrm{SO}_{4}$ 0,5 mol L ${ }^{-1}$, sendo agitadas por 30 minutos. A suspensão resultante foi filtrada em papel filtro Whatman $n^{\circ} 1$. O carbono orgânico dos extratos foi determinado pela digestão de $10 \mathrm{~mL}$ do filtrado com $1 \mathrm{~mL} \mathrm{~K}_{2} \mathrm{Cr}_{2} \mathrm{O}_{7}$ e $10 \mathrm{~mL}$ de uma mistura de $\mathrm{H}_{2} \mathrm{SO}_{4}$ e $\mathrm{H}_{3} \mathrm{PO}_{4}$ concentrado (1:1), em erlenmeyers de $50 \mathrm{~mL}$. Esta solução permaneceu em banho - maria a $90^{\circ} \mathrm{C}$ durante uma hora. Após resfriadas, as amostras receberam $10 \mathrm{~mL}$ de $\mathrm{H}_{2} \mathrm{O}$ deionizada. $\mathrm{O}$ excesso de $\mathrm{K}_{2} \mathrm{Cr}_{2} \mathrm{O}_{7}$ foi determinado por titulação com sulfato ferroso de amônio, utilizando-se difenilamina sulfonato de bário como indicador. Para saber a quantidade de dicromato consumida fez-se uma digestão em branco, utilizando todo o processo sem solo. O carbono orgânico extraído de cada amostra foi determinado da seguinte maneira:

$$
\mathrm{CBM}=(\mathrm{F}-\mathrm{NF}) / \mathrm{Kc})
$$

Onde: $\mathrm{F}$ = amostras fumigadas;

$$
\mathrm{NF}=\text { amostras não fumigadas; }
$$

Kc = coeficiente de correção 0,30 proposto por Feigl et al. (1995).

Os resultados foram expressos em:

$$
\mu \mathrm{g} \mathrm{C} \mathrm{g}^{-1} \text { solo }
$$




\subsubsection{Nitrogênio da Biomassa microbiana}

O nitrogênio da biomassa microbiana (NBM), foi determinado pelo método da fumigação-extração (Vance et al.,1987) e a medida do nitrogênio reativo com ninidrina foi adaptado por Joergensen \& Brookes (1990) e Joergensen (1996).

Após a obtenção do extrato a partir da fumigação-extração como descrita no item anterior, foi retirado 0,6 mL dos filtrados e adicionados a tubos de ensaio de $20 \mathrm{~mL}$, adicionou-se 1,4 mL de tampão de ácido cítrico, e lentamente foi colocado $1 \mathrm{~mL}$ do reagente de ninidrina misturando-o completamente. Os tubos foram aquecidos em banho-maria por 20 minutos a $100^{\circ} \mathrm{C}$. As soluções então foram esfriadas até atingirem a temperatura ambiente, posteriormente adicionados $4 \mathrm{~mL}$ de água com etanol (1:1). Os tubos foram agitados para realização das leituras em espectrofotômetro a $570 \mathrm{~nm}$. Os cálculos das concentrações de nitrogênio reativo à ninidrina produzidas foram feitos pelas referências plotadas no gráfico com a solução padrão nas concentrações de 0,75 , 150, 300, 500, 750, 1000, 1250, 1500 e $1750 \mu \mathrm{M}$ de leucina.

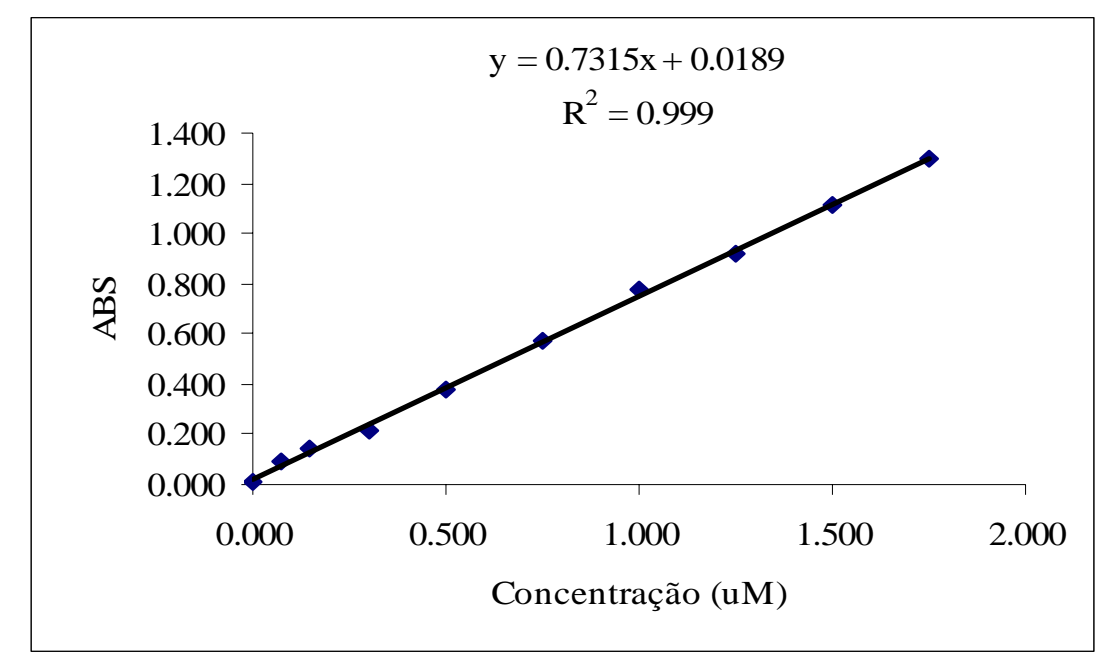

Figura 12 - Expressão gerada através do gráfico para o cálculo da concentração de nitrogênio reativo à ninidrina

Os resultados foram expressos em: $\mu \mathbf{g} \mathbf{N} \mathbf{g}^{\mathbf{- 1}}$ solo 


\subsubsection{Respiração Basal}

A respiração basal (RB) do solo foi determinada pelo método de Isermeyer descrito por Alef (1995), através da quantificação do dióxido de carbono $\left(\mathrm{CO}_{2}\right)$ liberado no processo de respiração microbiana durante dez dias de incubação.

Das amostras coletadas retirou-se o equivalente a $50 \mathrm{~g}$ de solo, que foram incubados em frascos de vidro com tampa vedante, e volume de 1,5L contendo um frasco com $10 \mathrm{~mL}$ da solução de $\mathrm{NaOH}$ 0,05 $\mathrm{M}$ para absorver o $\mathrm{CO}_{2}$ liberado do solo.

Após 24 horas de incubação a $28^{\circ} \mathrm{C}$ retirou-se o frasco com a solução de $\mathrm{NaOH}$ e adicionou-se $1 \mathrm{~mL}$ de $\mathrm{BaCL}_{2}$ e três gotas do indicador fenolftaleina. A quantidade de $\mathrm{CO}_{2}$ liberado do solo foi determinada após titulação do excedente de $\mathrm{NaOH}$ com solução de $\mathrm{HCl} 0.05$ M. O cálculo da respiração utilizando-se o método de titulação com a captura de $\mathrm{CO}_{2}$ por $\mathrm{NaOH}$ é o seguinte:

$$
\left.\mathrm{CO}_{2}(\mathrm{mg}) \mathrm{SS} / \mathrm{t}=(\mathrm{Vo}-\mathrm{V}) * 1.1\right) / \mathrm{Ps}
$$

Em que:

SS = peso de solo seco.

$\mathrm{t}=$ tempo de incubação (horas)

Vo = volume de HCl usado para titulação da testemunha sem amostra (mL)

$\mathrm{V}=$ volume de $\mathrm{HCl}$ usado para titulação da amostra de solo

Ps = peso seco de 1 grama de solo úmido

1.1 = fator de conversão $(1 \mathrm{~mL} 0.05 \mathrm{M} \mathrm{NaOH}=1.1 \mathrm{mg} \mathrm{CO} 2)$

Os resultados foram expressos em:

$\mathrm{mg} \mathrm{CO}_{2} \mathrm{~g}^{-1}$ solo h$^{-1}$ 


\subsubsection{Quociente metabólico}

O quociente metabólico $\left(\mathbf{q} \mathbf{C O}_{2}\right)$ foi determinado como proposto por Anderson \& Domsch, (1993) que é interpretado pela razão (respiração basal):(biomassa microbiana). Este quociente tem suporte na teoria de Odum (1983) sobre a estratégia de desenvolvimento do ecossistema segundo a qual a relação (respiração total):(biomassa total) diminui com o tempo ou com a sucessão do ecossistema, podendo este modelo ser utilizado para definir e quantificar mais claramente a atividade microbiana.

Os resultados foram expressos em:

$$
\mu \mathrm{g} \mathrm{CO} / \mu \mathrm{g} \mathrm{C} \mathrm{g}^{-1} \text { solo }^{-1}
$$

\subsubsection{Determinação da hidrólise do diacetato de fluoresceína (FDA)}

Para a determinação da FDA utilizou-se a metodologia proposta por Diack (1997).

Pesaram-se 3g de solo úmido referente a cada amostra em frascos de Erlenmeyer de $100 \mathrm{~mL}$ e posteriormente adicionaram-se $40 \mathrm{~mL}$ de solução tampão fosfato de sódio com fluoresceína. Os frascos foram tampados e incubados em rotação a 35 C por 24 horas.

Após este período foram adicionados $2 \mathrm{~mL}$ de acetona para que as reações fossem interrompidas. As amostras foram centrifugadas a 3840 rpm durante 5 minutos e os sobrenadantes obtidos foram filtrados em papel de filtro Whatman $n^{\circ} 42$.

As mensurações da absorção foram feitas em espectrofotômetro a 490nm.

Os cálculos das concentrações da fluoresceína produzida foram feitos pelas referências plotadas no gráfico com a solução padrão nas concentrações: 0, 100, 200, 300, 400, 500, 600 e 700 mg de fluoresceína (Figura 13). 


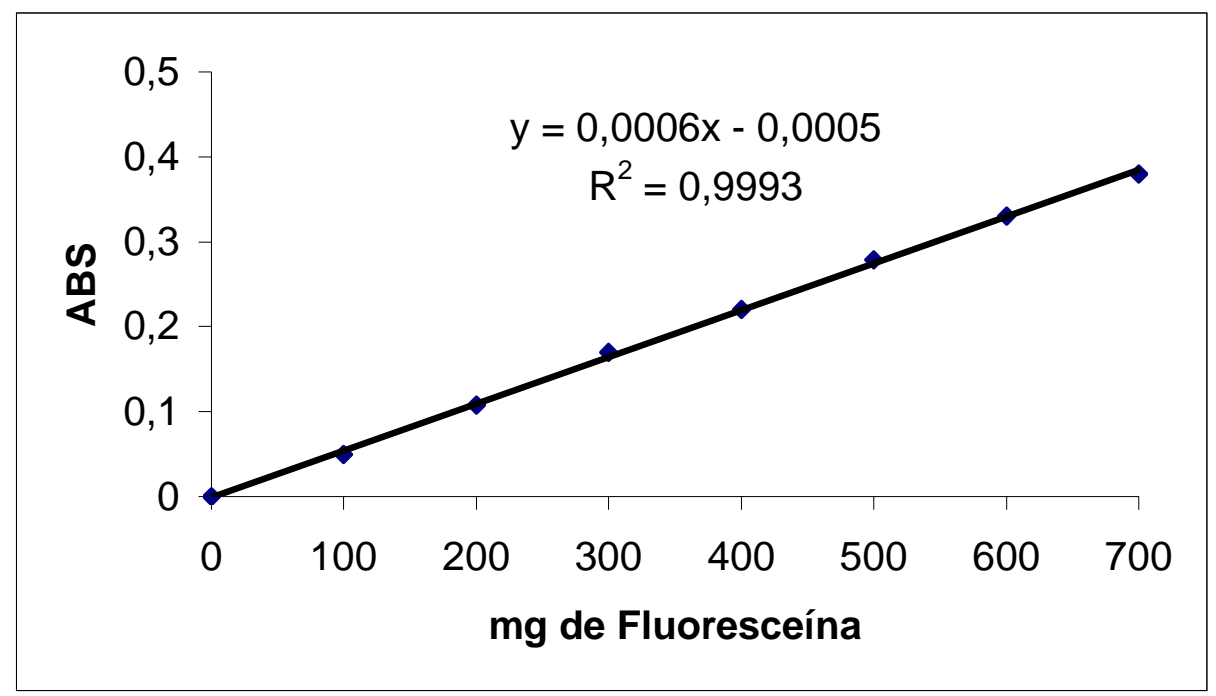

Figura 13 - Expressão gerada através do gráfico para o cálculo da concentração de fluoresceína produzida

Os resultados foram expressos em:

\section{mg fluoresceína $\mathrm{g}^{-1}$ solo dia $^{-1}$}

\section{Soluções utilizadas:}

- $\mathrm{Na}_{3} \mathrm{PO}_{4} 12 \mathrm{H}_{2} \mathrm{O}$ : solução tampão fosfato de sódio $(60 \mathrm{mM}, \mathrm{pH} 7,0)$ : dissolver 22,74 g de fosfato de sódio em $800 \mathrm{~mL}$ de água destilada, ajustar o pH para 7.0 com ácido clorídrico e completar para 1L;

- Diacetato de fluoresceína: adicionar 10mg de fluoresceína dissolvida em acetona pura em 1L de solução tampão.

- Acetona e água $(1: 1)$

- Solução padrão 2,6 mM: dissolver 0.5g de fluoresceína sódica em 500 mL de água destilada. 


\subsubsection{Determinação da atividade da $\beta$ - glicosidase}

A atividade da $\beta$ - glicosidase foi determinada segundo a metodologia proposta por Eivazi \& Tabatabai (1988).

Foi pesado $1 \mathrm{~g}$ de solo de cada amostra em Erlenmeyer de $50 \mathrm{~mL}$, e em seguida foram adicionados: 0,25 mL de tolueno, $4 \mathrm{~mL}$ de MUB (pH 6.0), $1 \mathrm{~mL}$ da solução de PNG.

Os frascos foram fechados e agitados por alguns segundos, posteriormente levados para a incubadora por 1 hora a $37^{\circ} \mathrm{C}$.

Após este período, com os frascos abertos, foram adicionados 1,0 mL de $\mathrm{CaCl}_{2} \mathrm{e}$ 4,0 mL do tampão THAM $(0,1 \mathrm{M}) \mathrm{pH} 12$ e depois de agitados foram filtrados em papel Whatman $\mathrm{n}^{\circ} 12$.

As leituras foram realizadas em espectrofotômetro a 400nm.

Os cálculos das concentrações de $\rho$-nitrofenol produzidas foram feitos pelas referências plotadas no gráfico com a solução padrão nas concentrações de $0 ; 10 ; 20$; 30; 40 e $50 \mu$ g de $\rho$-nitrofenol (PNF) (Figura 14).

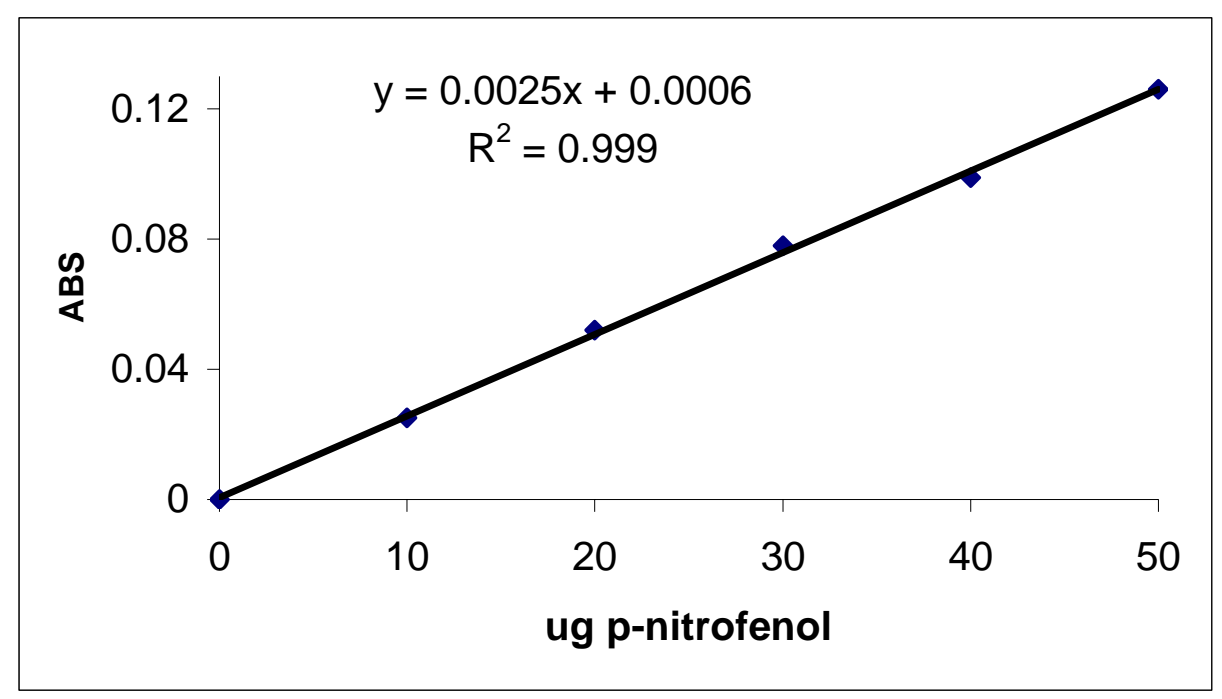

Figura 14 - Expressão gerada através do gráfico para o cálculo da concentração de $\rho$ nitrofenol produzido 
Os resultados foram expressos em:

$$
\mu \mathrm{g} \rho \text {-nitrofenol } \mathrm{g}^{-1} \text { solo }^{-1}
$$

\section{Soluções utilizadas:}

- Tampão universal (MUB), solução estoque: dissolver 12,1 g de tris (hidroximetil) aminometano (THAM); 11,6 g de ácido maleico; 14g de ácido cítrico e 6,3 g de $\mathrm{H}_{3} \mathrm{BO}_{4}$ em $488 \mathrm{~mL}$ de $\mathrm{NaOH}(1 \mathrm{M})$ e diluir a solução para $1 \mathrm{~L}$ com água destilada. Estocar a solução em geladeira a $4^{\circ} \mathrm{C}$.

- Tampão universal, pH 6,0: em 200 mL de MUB da solução estoque em um becker de $500 \mathrm{~mL}$ e titular a solução com $\mathrm{HCl}$ até atingir pH 6,0. Transferir para um balão volumétrico de 1L e completar o volume.

- $\rho$-nitrofenol- $\beta$-D-glicosídeo (PNG) 0,025 M: dissolver 0,377 g de PNG em 40 mL de MUB (pH 6,0), após a dissolução, completar a solução para $50 \mathrm{~mL}$ com MUB (pH 6,0). Estocar a solução em geladeira (no máximo por 4 dias).

- $\mathrm{CaCl}_{2}$ (0,5 M): dissolver 73,5 g de $\mathrm{CaCl}_{2} 2 \mathrm{H}_{2} \mathrm{O}$ em $700 \mathrm{~mL}$ de água destilada, completar o volume para $1 \mathrm{~L}$.

- $\mathrm{NaOH}(0,5 \mathrm{M})$ : dissolver 20 g de $\mathrm{NaOH}$ em $700 \mathrm{~mL}$ de água destilada, completar o volume para $1 \mathrm{~L}$ com água destilada.

- $\quad$ THAM (0,1M) pH 10: dissolver 12,2 g de THAM em $800 \mathrm{~mL}$ de água, ajustar o $\mathrm{pH}$ e completar o volume para $1 \mathrm{~L}$ com água destilada.

- $\quad$ THAM (0,1M) pH 12: dissolver 12,2 g de THAM em 800 mL de água, ajustar o $\mathrm{pH}$ adicionando $\mathrm{NaOH}(0,5 \mathrm{M})$ e completar o volume para $1 \mathrm{~L}$ com água destilada

- Solução padrão: dissolver 1,0 g de $\rho$-nitrofenol em $700 \mathrm{~mL}$ de água e completar a solução para 1 L com água destilada. Estocar na geladeira. 


\subsubsection{Determinação da atividade da urease}

A determinação da atividade da urease se deu através do método descrito por Tabatabai \& Bremner (1972).

Foram pesados $5 \mathrm{~g}$ de solo referente às amostras em frascos de $50 \mathrm{~mL}$ e adicionaram-se 0,2 mL de tolueno, $9 \mathrm{~mL}$ de THAM (0,05M) pH 9 e $1 \mathrm{~mL}$ de solução com uréia $\left(0,2 \mathrm{~mol} \mathrm{~L}^{-1}\right)$, deixando os por 2 horas em repouso na incubadora a $37^{\circ} \mathrm{C}$.

Após este período foram adicionados $35 \mathrm{~mL}$ de $\mathrm{KCl}-\mathrm{Ag}_{2} \mathrm{SO}_{4}$ para que a reação fosse interrompida deixando os frascos por 5 minutos à temperatura ambiente, completando-os posteriormente para $50 \mathrm{~mL}$ de $\mathrm{KCl}-\mathrm{Ag}_{2} \mathrm{SO}_{4}$ e agitando por alguns segundos.

Para a estimativa de amônia liberada foram pipetados $20 \mathrm{~mL}$ da suspensão de solo resultante dentro de um frasco de destilação contendo $0,2 \mathrm{~g} \mathrm{MgO}$, onde se determina o $\mathrm{N}_{-} \mathrm{NH}_{4}^{+}$liberado pelo vapor da destilação através da titulação com $\mathrm{H}_{2} \mathrm{SO}_{4}$ (0.005 mol L $\left.{ }^{-1}\right)$.

Para cada amostra foi feita amostra controle, sendo que a uréia foi adicionada somente após a solução de $\mathrm{KCl}-\mathrm{Ag}_{2} \mathrm{SO}_{4}$.

Para a determinação da atividade da urease usou-se a seguinte fórmula:

\section{(C*50)/PSS*5}

Onde:

$\mathrm{C}=$ quantidade de ácido gasto para a titulação

50 = quantidade de $\mathrm{KCl}-\mathrm{Ag}_{2} \mathrm{SO}_{4}$ adicionado

PSS = peso seco de $1 \mathrm{~g}$ de solo

$5=$ peso do solo inicial

$\mu \mathrm{g} \mathrm{N}-\mathrm{NH}_{4}^{+} \mathrm{g}^{-1}$ solo $\mathrm{h}^{-1}$

\section{Soluções utilizadas:}

- Tampão THAM (pH 9,0) 0,05 M: Dissolver 6,1 de THAM em 700 mL de água destilada, adicionar ácido sulfúrico (0,2M) até o pH atingir 9,0 e completar para 1 L. 
- Uréia 0,2 M: dissolver 1,2g de uréia em $80 \mathrm{~mL}$ do tampão completando posteriormente para $100 \mathrm{~mL}$ com o mesmo tampão.

- Cloreto de potássio (2,5 M) sufalto de prata (100 ppm) $\mathrm{KCl}$ - $\mathrm{Ag}_{2} \mathrm{SO}_{4}$ : dissolver 100 mg $\mathrm{Ag}_{2} \mathrm{SO}_{4}$ em $700 \mathrm{~mL}$ de água destilada, após adicionar $188 \mathrm{~g}$ de $\mathrm{KCl}$ nesta solução e completar para $1 \mathrm{~L}$.

- Solução padrão Amônia: dissolver 0,234 g de sulfato de amônio em 700mL de água e completar para 1L. Cada ml contêm $50 \mu \mathrm{g} \mathrm{N}-\mathrm{NH}_{4}^{+}$.

\subsection{Avaliação estatística dos dados}

Foram realizadas Análises de Variância (ANOVA) para verificar as diferenças entre as médias dos atributos bioquímicos e das análises químicas e física do solo entre as estações e ecossistemas avaliados. Quando estas ocorreram, foi aplicado o teste de Tukey ao nível de 5\%. Para as análises estatísticas foi utilizado o aplicativo estatístico SAS. 


\section{RESULTADOS E DISCUSSÃO}

\subsection{Atributos físico e químicos}

A avaliação granulométrica (Tabela 6) mostra a mesma textura (argilosa) para a profundidade de $0-10 \mathrm{~cm}$ em todos os solos analisados. A fração argila regula as propriedades físicas e químicas do solo, agindo como centro de atividade, em cujo redor ocorrem reações químicas e trocas de substâncias nutritivas. Além disso, mediante a atração de íons para a sua superfície protegem temporariamente as substâncias nutritivas essenciais contra a lixiviação, liberando-as, então, lentamente, para a absorção pelas plantas (Brady, 1989).

A textura argilosa apresenta grande superfície específica e propriedades como o tipo dominante de carga (-/+), sendo predominantemente encontradas cargas eletricamente negativas (Lopes \& Guilherme, 1992), importantes na interação com os microrganismos, afetando aspectos importantes da ecologia microbiana, como a sobrevivência, sucessão e interação entre os organismos, além de sua atividade (Moreira \& Siqueira, 2002).

Os microrganismos também são classificados de acordo com a faixa de $\mathrm{pH}$ adequada para cada espécie, portanto, o valor encontrado para este parâmetro irá indiretamente influenciar no tipo da comunidade microbiana que habitará o ambiente em questão, interferindo nos processos biológicos, principalmente nas atividades enzimáticas, que são, em sua maioria, dependentes do $\mathrm{pH}$.

A capacidade ou poder tampão do solo diz respeito à resistência do solo em ter o valor de seu $\mathrm{pH}$ alterado, parâmetro este regulado principalmente pelo teor de argilas ou de matéria orgânica com alta CTC. 
O pH exerce influência sobre a solubilidade e, portanto sobre a disponibilidade de vários nutrientes e de outros elementos, que podem ser tóxicos para os microrganismos. Os solos do presente estudo devem ter um forte poder tampão, pois apresentam propriedades favoráveis, como textura argilosa, alto teor de material orgânico e alta acidez potencial, garantindo pequenas variações nas funções dependentes de $\mathrm{pH}$.

Tabela 6. Resultado da análise granulométrica realizada na profundidade de 0-10 cm nos solos sob os ecossistemas avaliados: Mata Natural do PETAR (MNP), Mata Natural da Barra do Chapéu (MNBC), Mata Plantada do PETAR (MPP), Mata Natural de Campos do Jordão (MNCJ), Mata Plantada de Campos do Jordão (MPCJ) e Mata Plantada de Campos do Jordão com ocorrência de incêndio (MPCJi)

\begin{tabular}{ccccc}
\hline Áreas & $\begin{array}{c}\text { Argila (\%) } \\
<0,002 \mathrm{~mm}\end{array}$ & $\begin{array}{c}\text { Areia (\%) } \\
0,02-2 \mathrm{~mm}\end{array}$ & $\begin{array}{c}\text { Silte (\%) } \\
0,002-0,02 \mathrm{~mm}\end{array}$ & Textura \\
\hline MNP & 53 & 15 & 32 & argilosa \\
MNBC & 51 & 41 & 8 & argilosa \\
MPP & 56 & 19 & 25 & argilosa \\
MNCJ & 44 & 46 & 10 & argilosa \\
MPCJ & 35 & 43 & 23 & argilosa \\
MPCJi & 39 & 41 & 19 & argilosa \\
\hline
\end{tabular}

Dentre os solos avaliados, vale destacar o solo da Mata Nativa do PETAR (MNP), por ser o único a apresentar $\mathrm{pH}$ equivalente a 5,6, classificado como um solo de acidez fraca. Segundo Lopes \& Guilherme (1996), neste $\mathrm{pH}$ a disponibilidade do alumínio não ocorre, o que explica a elevada saturação por bases (V) neste solo (77,9\%). $\mathrm{V}$ refere-se à porcentagem das cargas negativas passíveis de trocas a $\mathrm{pH}$ 7,0 que estão ocupados por cátions $\left(\mathrm{Ca}^{2+} \mathrm{Mg}^{2+} \mathrm{K}^{+}\right.$e às vezes, $\left.\mathrm{Na}^{+}\right)$com exceção de $\mathrm{H}^{+}$e $\mathrm{Al}^{3+}$. Esse parâmetro é utilizado para classificar solos considerados férteis ( $\mathrm{V}>50$ \%), donde pode 
ser concluído que o único solo a ser considerado fértil neste trabalho é o da Mata Natural do PETAR (MNP).

Outro fator de destaque neste solo está nos teores de cálcio $\left(101,9 \mathrm{mmol}_{\mathrm{c}} \mathrm{dm}^{-3}\right)$ e magnésio (25,3 $\left.\mathrm{mmol}_{\mathrm{c}} \mathrm{dm}^{-3}\right)$, considerados bastante elevados. Um fato talvez correlacionado com a riqueza de cálcio é a presença de várias carcaças de caracol encontradas nesta área. Cálcio e magnésio são elementos fornecidos principalmente pelos minerais do solo e a formação geológica do PETAR é constituída predominantemente por calcários e anfibolitos. Estes elementos no solo podem estar associados à matéria orgânica, sendo que os colóides orgânicos e inorgânicos adsorvem Ca e Mg, retendo-os em forma trocável, evitando perdas por lixiviação.

Tabela 7. Atributos químicos dos solos avaliados na profundidade de $0-10 \mathrm{~cm}$ sob os ecossistemas do PETAR: Mata Natural do PETAR (MNP), Mata Natural da Barra do Chapéu (MNBC) e Mata Plantada do PETAR (MPP)

\begin{tabular}{|c|c|c|c|}
\hline Atributos Químicos & MNP & MNBC & MPP \\
\hline pH $\left(0,01 M \mathrm{CaCl}_{2}\right)$ & 5,5 & 4,0 & 3,6 \\
\hline Matéria Orgânica (M.O.) $\quad$ (g.dm $\left.{ }^{-3}\right)$ & 66,6 & 54,3 & 65,9 \\
\hline Fósforo (P) & 18,6 & 18,9 & 12,4 \\
\hline$\left(\right.$ mmol $\left._{c} \cdot \mathrm{dm}^{-3}\right)$ & 1,6 & 3,0 & 2,3 \\
\hline$\left(\right.$ mmol $\left._{\mathbf{c}} \cdot \mathrm{dm}^{-3}\right)$ & 101,9 & 15,5 & 6,6 \\
\hline Magnésio (Mg) & 25,3 & 7,0 & 4,1 \\
\hline Carbono Total (COT) & 46,2 & 43,7 & 47,5 \\
\hline Nitrogênio Total (NT) & 1,29 & 0,85 & 1,20 \\
\hline Relação Carbono Nitrogênio (C:N) & 35,8 & 51,4 & 39,6 \\
\hline Acidez Potencial $(\mathrm{H}+\mathrm{Al})\left(\mathrm{mmol}_{\mathbf{c}} \cdot \mathrm{dm}^{-3}\right)$ & 30,4 & 79,9 & 173,7 \\
\hline$\left(\right.$ mmol $\left._{\mathbf{c} .} \cdot \mathbf{d m}^{-3}\right)$ & 159,2 & 105,4 & 186,7 \\
\hline Saturacão por Bases (V) & 77,9 & 24,0 & 7,4 \\
\hline
\end{tabular}


Tabela 8. Atributos químicos dos solos avaliados na profundidade de $0-10 \mathrm{~cm}$ sob os ecossistemas do PECJ: Mata Natural de Campos do Jordão (MNCJ), Mata Plantada de Campos do Jordão (MPCJ) e Mata Plantada de Campos do Jordão com ocorrência de incêndio (MPCJi).

\begin{tabular}{|c|c|c|c|}
\hline Atributos Químicos & MNCJ & MPCJ & MPCJi \\
\hline pH $\left(0,01 M \mathrm{CaCl}_{2}\right)$ & 3,7 & 3,5 & 3,8 \\
\hline Matéria Orgânica (M.O.) $\quad$ (g.dm ${ }^{-3}$ ) & 97,7 & 93,0 & 51,3 \\
\hline Fósforo (P) & 11,8 & 8,7 & 8,3 \\
\hline$\left(\mathbf{m m o l}_{\mathbf{c}} \cdot \mathrm{dm}^{-3}\right)$ & 2,6 & 2,9 & 2,3 \\
\hline$\left(\mathrm{mmol}_{\mathrm{c}} \cdot \mathrm{dm}^{-3}\right)$ & 5,2 & 1,5 & 2,8 \\
\hline Magnésio (Mg) & 3,8 & 1,4 & 1,9 \\
\hline Carbono Total (COT) & 58,4 & 51,71 & 34,3 \\
\hline Nitrogênio Total (NT) & 1,15 & 0,98 & 0,6 \\
\hline Relação Carbono Nitrogênio (C:N) & 50,7 & 52,7 & 57,2 \\
\hline Acidez Potencial $(\mathrm{H}+\mathbf{A l})\left(\right.$ mmol $\left._{\mathbf{c}} \cdot \mathbf{d m}^{-3}\right)$ & 195,7 & 219,1 & 107,8 \\
\hline$\left(\right.$ mmol $\left._{c} \cdot \mathrm{dm}^{-3}\right)$ & 207,3 & 224,9 & 114,8 \\
\hline Saturação por Bases (V) & 5,7 & 2,7 & 6,3 \\
\hline
\end{tabular}

A CTC (T) é definida como a quantidade de cátions adsorvida a pH 7,0, e os resultados obtidos mostraram, de um modo geral, alta CTC, o que era esperado devido à textura argilosa e principalmente pelo alto teor de matéria orgânica (M.O.) encontrado nestes solos, já que sua decomposição e transformações dão origem ao húmus. A fração orgânica humificada, além de fazer parte da matriz do solo, na forma de colóides orgânicos, exerce profundos efeitos nas suas propriedades. A CTC do húmus pode representar de 20 a 70\% da CTC total do solo (Moreira \& Siqueira, 2002). Esta importância está refletida nos dados obtidos no presente estudo, onde o menor teor de material orgânico apresentado nas áreas MNBC (Mata Natural da Barra do Chapéu) no PETAR e MPCJi (Mata Plantada com incidência de fogo de Campos do Jordão) 
acarretou uma menor CTC em relação às outras áreas analisadas, o que pode estar favorecendo maiores perdas de nutrientes por lixiviação nestas áreas. (Tabela 7 e 8).

A qualidade do resíduo incorporado ao solo influencia a disponibilidade de nutrientes através dos processos de imobilização e mineralização. Dependendo da relação C: $\mathrm{N}$ do material adicionado, pode ocorrer o esgotamento do $\mathrm{N}$ no caso de relação alta ou liberação do elemento mineralizado, se o resíduo tiver relação baixa. Os limites C:N entre esses dois fenômenos são pouco precisos, mais ainda não se conhecem procedimentos mais adequados para avaliar tal situação. Presume-se que uma relação C:N entre 17 e 35 favoreceria um processo de bioestabilização, ou seja, os processos de imobilização e mineralização seriam semelhantes. Para uma relação acima de 35, o processo seria predominantemente de imobilização do nitrogênio e para uma relação abaixo de 17 seria o de mineralização (Moreira \& Siqueira, 2002). Os dados obtidos no presente estudo sugerem, através da relação C: $\mathrm{N}$ do solo, que a serapilheira adicionada possui diminuta taxa de decomposição (possivelmente por altos teores de lignina e tamanho do material), favorecendo a imobilização, tornando a disponibilidade dos nutrientes diminuída, justificando, em parte, a baixa fertilidade destes solos. Somente a Mata Natural do PETAR apresenta uma relação C:N que favoreceria o processo de bioestabilização, induzindo que essa mata possui uma serapilheira de melhor qualidade quando comparada com as demais matas estudadas, podendo estar vinculada a maior diversidade da vegetação presente, já que esta é a principal responsável pela heterogeneidade da serapilheira (Tabela 7).

Segundo Herrera et al. (1978), florestas sobre solos de baixa fertilidade retornam menor quantidade de material formador de serapilheira em relação a solos férteis. Porém desenvolvem mecanismos para conservar nutrientes, como a absorção de nutrientes diretamente da serapilheira, através da associação entre fungos e raízes (micorrizas).

Souza et al. (2003) demostraram a importância desta associação para araucária como também reportaram grande número de fungos micorrízicos arbusculares (até 23 espécies) associados a araucária em áreas no PECJ. 


\subsection{Atributos biológicos}

\subsubsection{Carbono e Nitrogênio da biomassa microbiana}

Quando se estuda a comunidade microbiana e sua atividade em solos de mata, espera-se encontrar valores relativamente maiores quando comparados a solos com outros tipos de vegetação, menos exuberantes e até mesmo em solos sob culturas, já que esta microbiota é favorecida pela cobertura vegetal, que propicia um maior acúmulo de material orgânico, fornecendo maior fonte de nutrientes para o desenvolvimento da comunidade microbiana. Outro fator contribuinte para esta expectativa é que, em solos de mata, não há revolvimento, resultando na maior presença de raízes. A rizosfera foi definida por Hiltner como sendo a região do solo sob influência das raízes, onde é possível encontrar um número de até 1000 vezes mais microrganismos em relação a um solo não rizosférico (Cardoso \& Freitas, 1992 e Moreira \& Siqueira, 2002). Este fato decorre da exsudação de diversos tipos de materiais orgânicos, oriundos da fotossíntese, através das raízes, contribuindo para o aumento da matéria orgânica dessa região. O nãorevolvimento do solo mantêm intactas as hifas fúngicas que são facilmente destruídas por ações que perturbam a estrutura do solo (Evans \& Miller, 1988, 1990; Jasper et al., 1989 e McGonigle et al., 1990), favorecendo a micorrização das espécies florestais, possibilitando uma maior capacidade de absorção de água e nutrientes, sobrevivência em condições naturais, além de um maior crescimento (Marx et al., 1984).

Como descrito anteriormente, os parâmetros do presente estudo, foram avaliados por meio de quatro coletas, representadas por estações contrastantes. Os dados apresentados foram obtidos por meio de médias dentro das mesmas estações, já que estas não apresentaram diferenças significativas entre si pelo teste de Tukey a 5\%. Este fato é interessante no sentido de que não houve diferenças no espaço temporal, onde as amostras colhidas em anos diferentes, porém representando a mesma estação, mantiveram o mesmo comportamento para todos os parâmetros avaliados, podendo assim contribuir para um melhor monitoramento de possíveis alterações funcionais nestas áreas. 
Dentre os atributos estudados, a biomassa microbiana tem sido usada para avaliar as condições do solo, pois representa a fração responsável pela mineralização da matéria orgânica, assim como pela ciclagem de nutrientes. Pode ser enquadrada como o compartimento central do ciclo do carbono, representando um considerável reservatório de nutrientes, podendo exercer a função de reserva ou de fonte, dependendo da quantidade de energia que entra ou sai do sistema.

No Brasil, há poucos trabalhos envolvendo o estudo de atributos biológicos em ecossistemas de mata atlântica e em matas de araucária, sendo mais facilmente encontrados trabalhos que envolvam os diversos tipos de cultivo, ecossistemas de cerrado e amazônico e, principalmente, os solos de áreas degradadas. Os teores de carbono na biomassa microbiana, obtidos nas áreas estudadas, estão dentro dos valores descritos na literatura nos diversos ecossistemas florestais brasileiros, que variam de 109 a $1600 \mu \mathrm{g} \mathrm{C} \mathrm{g}^{-1}$ solo (Cabral et al., 2004; Carneiro, 2000; D’Andrea et al, 2002; GamaRodrigues et al., 1997; Matsuoka et al., 2003; Marchiori-Junior \& Mello, 2000; Melloni et al., 2001; Oliveira et al., 2001 e Pfenning et al., 1992). Esta larga faixa de valores do carbono da biomassa está vinculada à heterogeneidade existente nos diversos ecossistemas. Portanto, o valor isolado da biomassa microbiana não seria um indicador tão preciso e confiável para qualquer tipo de alteração, a não ser eventualmente e quando ocorre monitoramento do comportamento dessa biomassa por vários anos em uma mesma localidade. Assim, é necessário compor os valores obtidos com as demais variáveis analisadas para se poder compreender o comportamento da comunidade microbiana nos ecossistemas.

Os atributos biológicos sofrem grande influência sazonal, principalmente nas camadas superficiais do solo, onde as oscilações na umidade e temperatura são maiores (Campbell \& Bierderbeck, 1976, 1982; Cattelan \& Vidor, 1990 e Martinez \& Ramirez, 1978). Como foi discutido no diagrama climático do PETAR (Figura 6), as chuvas ocorridas ao longo dos anos estudados foram bem distribuídas, assim como a temperatura não teve mudanças bruscas. Mesmo assim, somente a Mata Natural do PETAR (MNP) não apresentou diferenças significativas entre as estações avaliadas (inverno e verão), o que pode estar indicando que este solo é menos vulnerável às 
mudanças climáticas, talvez pela maior proteção do solo através da cobertura vegetal, fazendo com que a incidência de raios solares seja menor, além da melhor conservação da umidade, favorecendo a existência de um microclima mais estável e sugerindo uma maior estabilidade do ecossistema (Bragagnolo, 1986; Wardle \& Parkinson, 1990). Fato semelhante pôde ser observado na Mata Natural de Campos do Jordão (MNCJ) pois , apesar do diagrama climático mostrar que houve períodos de estiagem e quedas acentuadas de temperatura, a mata natural não apresentou diferenças significativas de uma estação para outra, evidenciando como a cobertura do solo é importante para a manutenção do nível dos processos biológicos. Além de um microclima mais estáve,l o efeito rizosférico pode contribuir para manter uma maior resiliência (resistência a mudanças), onde a redundância nos componentes funcionais é um dos principais contribuintes. Isto pode ser indício de que nestas áreas (MNP e MNCJ) a diversidade da comunidade microbiana seja maior do que nas demais áreas avaliadas (Tabelas 9 e 10). As diferenças existentes na composição da serapilheira e no nível de cobertura das matas de araucária originam-se da sua constituição, pois sua formação não é homogênea nem contínua e sim com múltiplas associações e agrupamentos que vão variar de acordo com o local e o estádio da sucessão (Klein,1960).

Foi observada a influência da flutuação sazonal nas demais áreas estudadas mas, ao contrário do que se esperava, a Mata Natural da Barra do Chapéu (MNBC) apresentou, no inverno, 49,8\% a mais de carbono na biomassa microbiana do que no verão (Figura 15). É provável que o incêndio ocorrido (Figura 5) nesta área tenha efetuado uma rápida mineralização dos detritos acumulados, aumentando a oferta de nutrientes essenciais para o crescimento da comunidade microbiana. A mata plantada do PETAR (MPP) também obteve, na estação do inverno, 55,4 \% a mais de carbono na biomassa microbiana, quando comparada com a estação do verão. Como não foram observadas diferenças estatísticas no espaço temporal, a explicação mais plausível para este fenômeno pode estar nos altos índices pluviométricos registrados no verão, já que nestes solos, apesar da existência da cobertura vegetal, esta se apresenta de forma menos densa quando comparada à Mata Natural do PETAR (MNP), tornando os solos destas áreas mais vulneráveis às conseqüências trazidas pelo excesso de precipitação, ou seja, 
perdas de solo pelo processo de erosão e maiores perdas de nutrientes por lixiviação. Pode ainda ter ocorrido encharcamento temporário destes solos, tornando-os pouco aerados, o que poderia acarretar na redução da velocidade de muitas transformações e inibição completa de alguns processos microbianos (Figura15).

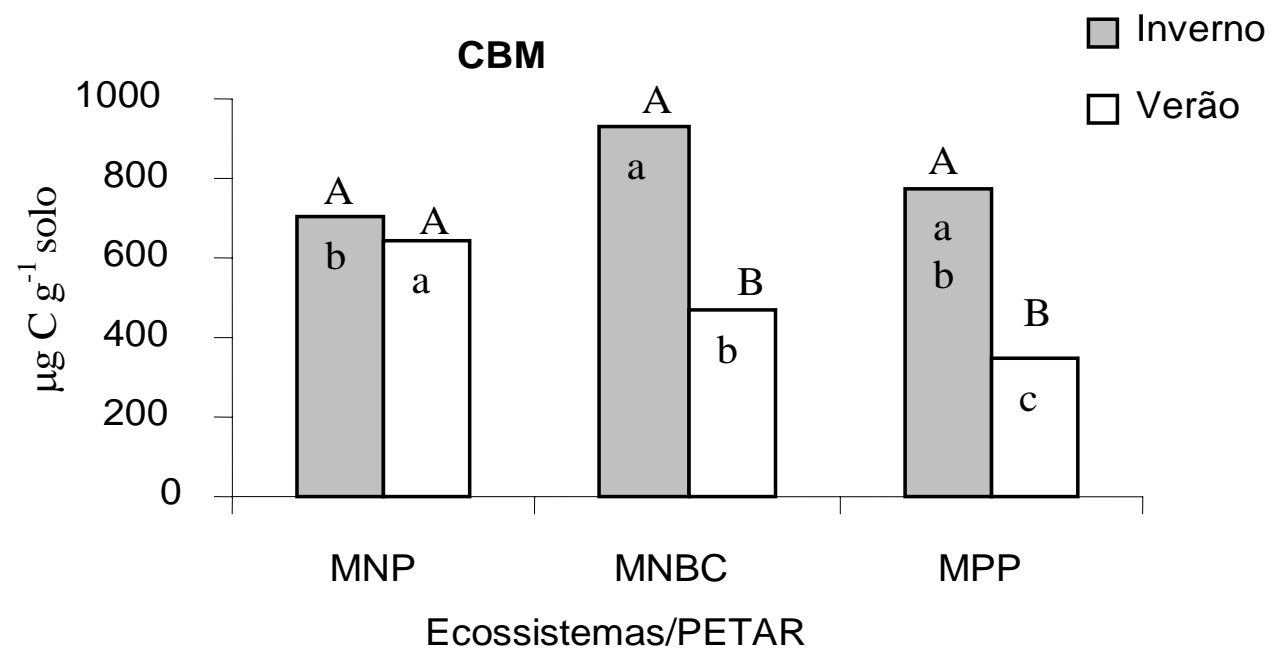

Figura 15 - Carbono da Biomassa Microbiana ( $\mu \mathbf{g} \mathbf{C} \mathbf{g}^{-1}$ solo) nos ecossistemas do PETAR: Mata Natural do PETAR (MNP), Mata Natural da Barra do Chapéu (MNBC) e Mata Plantada do PETAR (MPP) nas estações do inverno e verão. Letras iguais minúsculas dentro das barras representando à mesma estação (entre áreas) ou maiúsculas fora das barras representando a mesma área (entre estações), não diferem entre si estatisticamente ao nível de $5 \%$ de probabilidade de acordo com o teste de Tukey

Para as áreas do PECJ, as flutuações sazonais foram as esperadas, já que houve diferenças significativas, sendo que no verão a Mata Plantada de Campos do Jordão (MPCJ) e a Mata Plantada de Campos do Jordão com a incidência de fogo (MPCJi) obtiveram valores de 15,6 e 37\% mais altos de carbono na biomassa microbiana do que no inverno, o que pode estar relacionado não só com o período de estiagem e 
temperaturas mais baixas ocorridos nesta região, como também ter sido novamente causado pela diferença na cobertura vegetal (Figura 16).

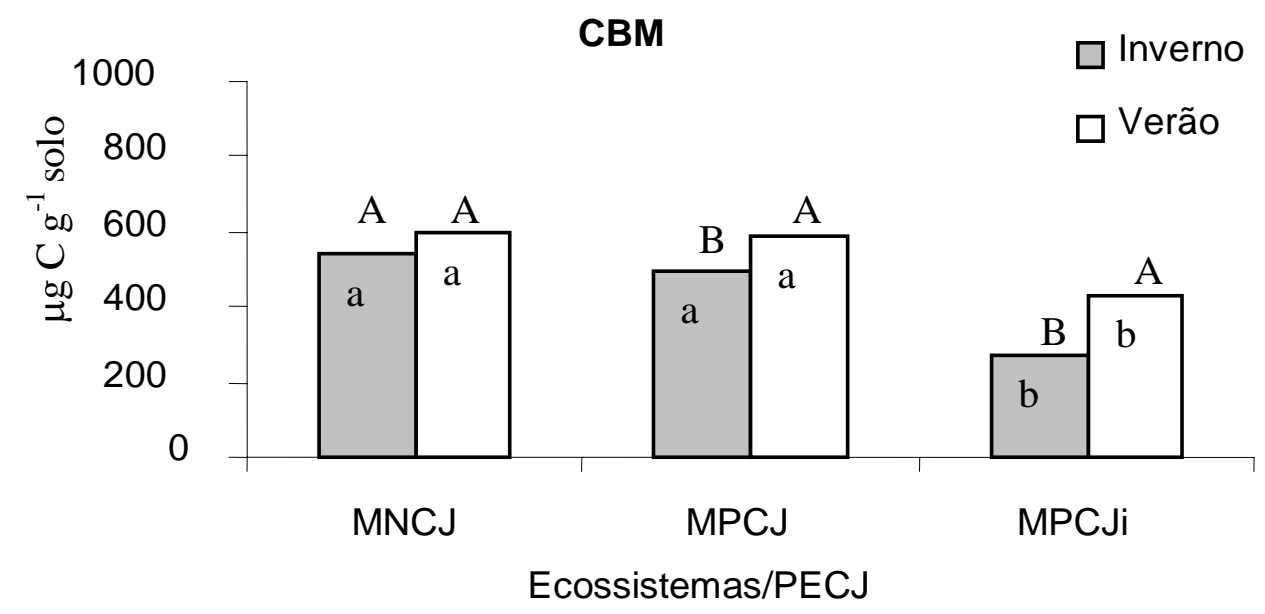

Figura 16 - Carbono da Biomassa Microbiana ( $\mu$ g C $\mathbf{g}^{-1}$ solo) nos ecossistemas do PECJ: Mata Natural de Campos do Jordão (MNCJ), Mata Plantada de Campos do Jordão (MPCJ) e Mata Plantada de Campos do Jordão com ocorrência de incêndio (MPCJi) nas estações do verão e inverno. Letras iguais minúsculas dentro das barras representando à mesma estação (entre áreas) ou maiúsculas fora das barras representando a mesma área (entre estações), não diferem entre si estatisticamente ao nível de 5\% de probabilidade de acordo com o teste de Tukey

O nitrogênio da biomassa microbiana para as matas do PETAR mostrou o mesmo comportamento do carbono da biomassa microbiana, ou seja, os valores encontrados para a Mata Natural do PETAR (MNP) não mostraram diferenças significativas com relação à sazonalidade, ao contrário das demais áreas estudadas no PETAR, que forneceram valores de nitrogênio na biomassa microbiana de 61 e 57 \% maiores no inverno para a Mata Natural da Barra do Chapéu (MNBC) e para a Mata Plantada do PETAR (MPP) respectivamente. A Mata Natural do PETAR (MNP) 
também apresentou valores de nitrogênio na biomassa microbiana significamente maiores do que as demais áreas estudadas no PETAR, sendo estes 31 e 70 \% maiores do que na Mata Natural da Barra do Chápeu (MNBC) e de 36 e 69\% maiores do que na Mata Plantada do PETAR nas estações de inverno e verão, respectivamente (Figura 17).

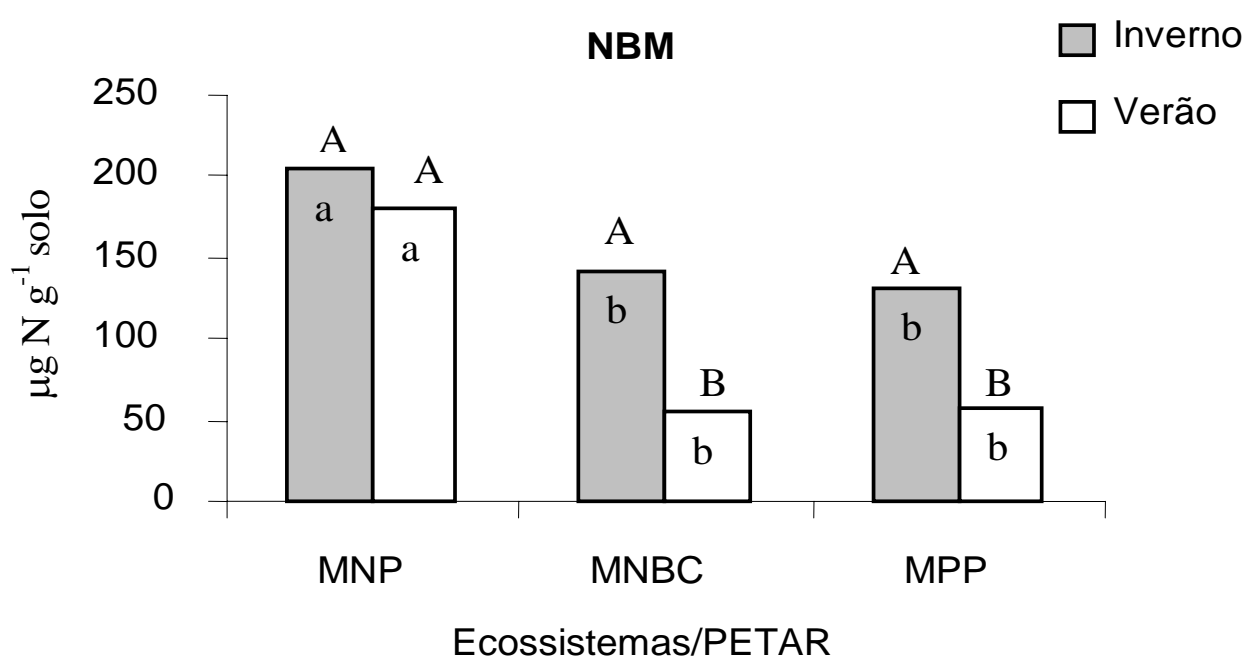

Figura 17 - Nitrogênio na Biomassa Microbiana ( $\mu \mathrm{g} \mathrm{N} \mathrm{g}{ }^{-1}$ solo) nos ecossistemas do PETAR: Mata Natural do PETAR (MNP), Mata Natural da Barra do Chapéu (MNBC) e Mata Plantada do PETAR (MPP) nas estações do verão e inverno. Letras iguais minúsculas dentro das barras representando à mesma estação (entre áreas) ou maiúsculas fora das barras representando a mesma área (entre estações), não diferem entre si estatisticamente ao nível de $5 \%$ de probabilidade de acordo com o teste de Tukey

Para as matas do PECJ, a única a apresentar diferença significativa com relação à sazonalidade foi a Mata Plantada com incidência de incêndio (MPCJi), o que pode estar diretamente ligado à menor cobertura vegetal e, conseqüentemente, ao menor acúmulo de matéria orgânica, portanto menor fonte de nutrientes para o desenvolvimento da comunidade microbiana, além de estar mais susceptível às variações climáticas (Figura18). 


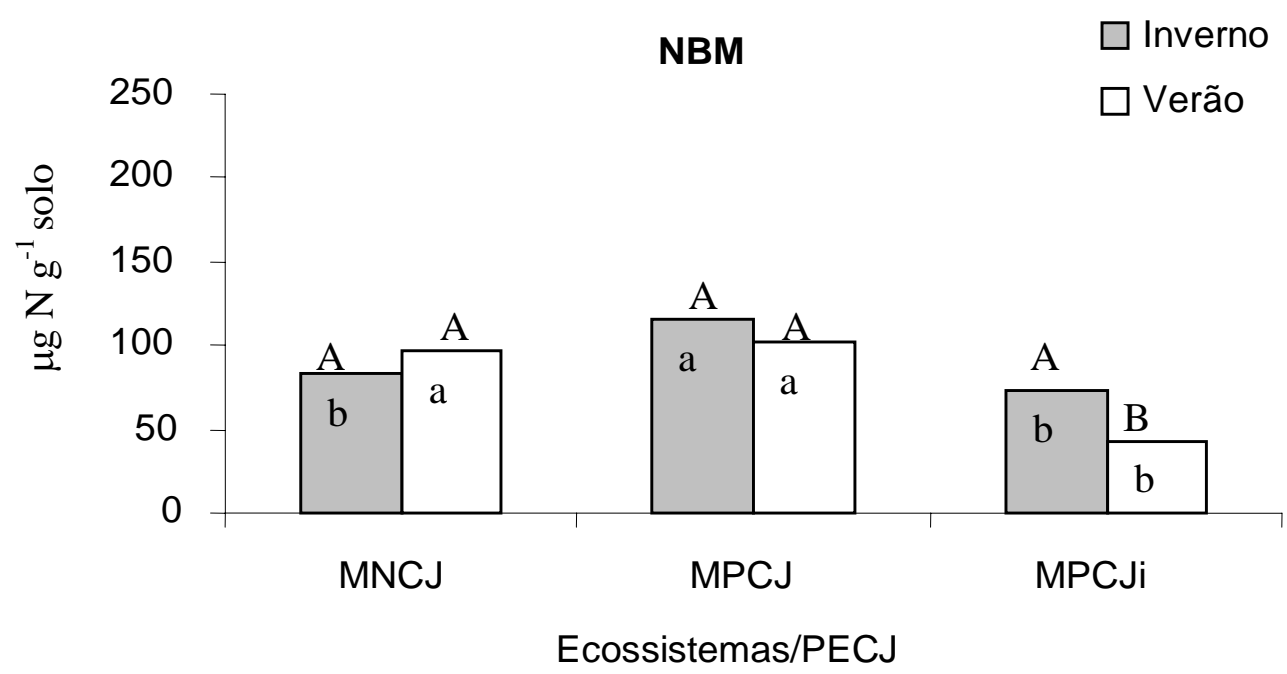

Figura 18 - Nitrogênio na Biomassa Microbiana ( $\mu \mathbf{g} \mathbf{N ~ g}^{\mathbf{- 1}}$ solo) nos ecossistemas do PECJ: Mata Natural de Campos do Jordão (MNCJ), Mata Plantada de Campos do Jordão (MPCJ) e Mata Plantada de Campos do Jordão com ocorrência de incêndio (MPCJi) nas estações de verão e inverno. Letras iguais minúsculas dentro das barras representando à mesma estação (entre áreas) ou maiúsculas fora das barras representando a mesma área (entre estações), não diferem entre si estatisticamente ao nível de $5 \%$ de probabilidade de acordo com o teste de Tukey

Observou-se uma tendência geral das Matas Naturais apresentarem os maiores teores de carbono e nitrogênio na biomassa microbiana. Este fato pode estar vinculado à teoria do desenvolvimento e evolução do ecossistema proposta por Odum (1983), segundo a qual o processo de sucessão ecológica envolve mudanças na estrutura de espécies e processos da comunidade ao longo do tempo e, quando se comparam as matas naturais com as plantadas, fica claro que as modificações dentro destes ecossistemas são diferentes, lembrando que o ambiente físico ajuda a determinar a velocidade destas modificações. 
Referir-se a uma mata plantada implica dizer que esta já sofreu uma interferência antrópica, e as tendências das mudanças ocorridas em seu processo de sucessão são diferentes das matas naturais, portanto não se pode esperar que ecossistemas que sofreram algum tipo de interferência tenham o mesmo desempenho das funções existentes em ecossistemas naturais.

Os solos de todas as matas do PECJ, assim como os solos da Mata Natural da Barra do Chapéu (MNBC) e da Mata Plantada do PETAR (MPP) são considerados ácidos e de baixa fertilidade, além de apresentar altas relações C:N, indicando processos lentos de decomposição, propiciando a imobilização do carbono e do nitrogênio na biomassa microbiana, mostrando que estes solos estão funcionando como reservatório destes elementos. Segundo Odum (1983), existe a tendência do ecossistema reter e conservar uma maior quantidade de nutrientes ao longo do seu processo de sucessão, fazendo com que fique menos dependente de novas entradas, tendo como estratégia geral da sucessão uma eficiência crescente na utilização de energia e nutrientes.

\subsubsection{Respiração Basal e quociente metabólico $\left(q \mathrm{CO}_{2}\right)$}

A respiração basal tem sido utilizada para avaliar a atividade geral da biomassa microbiana, podendo ser altamente influenciada por diversos fatores no solo, como teor de umidade, temperatura, estrutura e disponibilidade de nutrientes (Alef \& Nannipieri, 1995).

Insam \& Domsch (1988) relatam que, na medida em que uma determinada biomassa microbiana se torna mais eficiente, menos carbono é perdido $\mathrm{como}^{\mathrm{CO}} \mathrm{CO}_{2}$ pela respiração e uma fração significativa de carbono é incorporada à biomassa microbiana. Desta forma, considerando a mesma constituição da comunidade microbiana, uma biomassa microbiana "eficiente” teria menor taxa de respiração em relação a uma biomassa "ineficiente".

As Matas do PECJ apresentaram, para a respiração basal, diferenças significativas entre as épocas estudadas, sendo as maiores médias no verão. Este fato pode ser explicado pela ocorrência de um período de estiagem e temperaturas mais 
baixas no inverno, lembrando que, as variáveis temperatura e precipitação são importantes na formação da matéria orgânica do solo e que os microrganismos são dependentes da disponibilidade desta matéria orgânica assim como de aeração, umidade e temperatura para o seu desenvolvimento, além de contribuir para a estabilidade do ecossistema (Wardle \& Parkinson, 1990) (Figura 19).

Respiração Basal

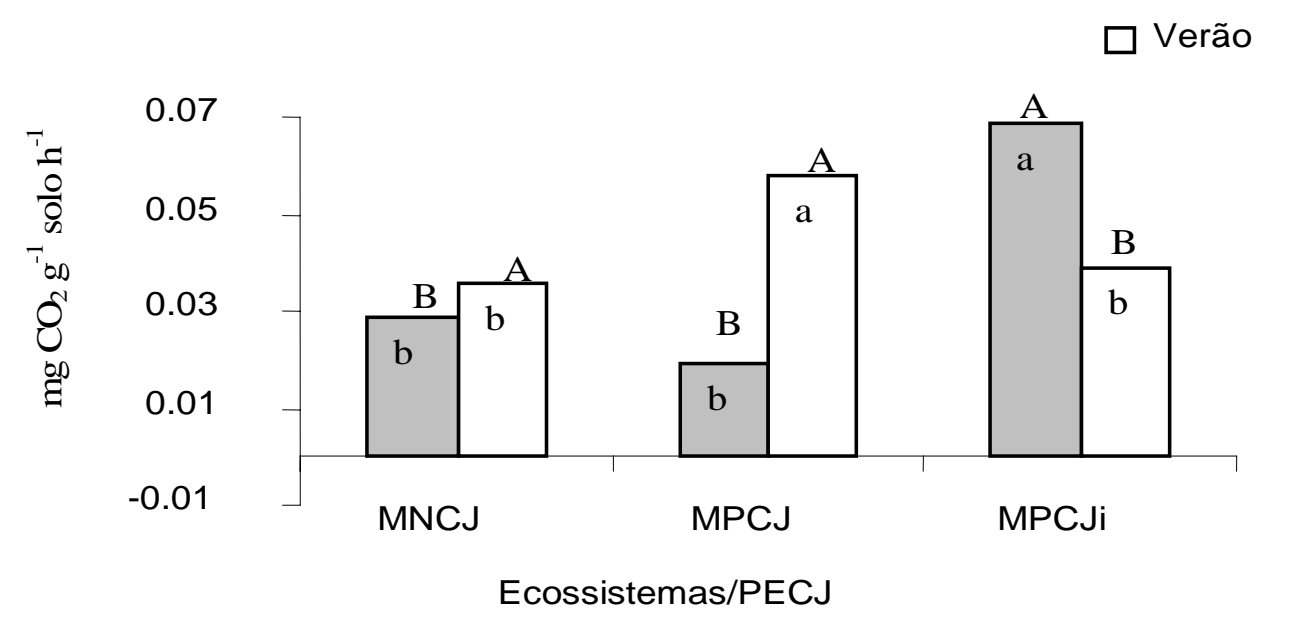

Figura 19 - Respiração Basal (mg $\mathbf{C O}_{2} \mathbf{g}^{-\mathbf{1}}$ solo $\mathbf{h}^{-\mathbf{1}}$ ) nos ecossistemas do PECJ: Mata Natural de Campos do Jordão (MNCJ), Mata Plantada de Campos do Jordão (MPCJ) e Mata Plantada de Campos do Jordão com ocorrência de incêndio (MPCJi) nas estações de verão e inverno. Letras iguais minúsculas dentro das barras representando à mesma estação (entre áreas) ou maiúsculas fora das barras representando a mesma área (entre estações), não diferem entre si estatisticamente ao nível de 5\% de probabilidade de acordo com o teste de Tukey

De modo geral, todas as matas estudadas apresentaram baixos valores de respiração e altos valores de carbono na biomassa, o que evidencia que as comunidades microbianas destes ecossistemas perdem menos carbono na forma de $\mathrm{CO}_{2}$ através da respiração, e uma fração significativa de carbono está sendo incorporada na constituição 
da biomassa microbiana, sugerindo que as comunidades avaliadas se encontram num estádio de sucessão mais avançado, no qual a retenção e conservação de nutrientes são maiores (Anderson \& Domsch, 1990; Insam \& Haselwandter, 1989; Kieft et al.,1987 e Odum, 1983) onde a comunidade microbiana utiliza as substâncias orgânicas mais para o seu crescimento do que para a sua manutenção (Mader et al., 2002) (Figuras 19 e 20).

Respiração Basal

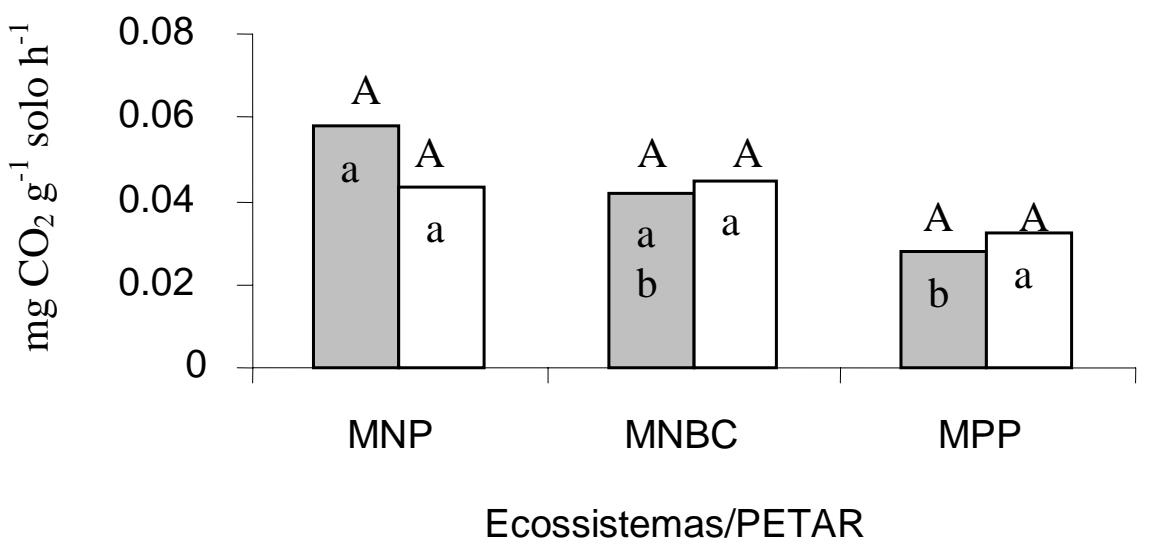

Figura 20 - Respiração Basal (mg $\mathbf{C O}_{2} \mathbf{g}^{-\mathbf{1}}$ solo $\mathbf{h}^{\mathbf{- 1}}$ ) nos ecossistemas do PETAR: Mata Natural do PETAR (MNP), Mata Natural da Barra do Chapéu (MNBC) e Mata Plantada do PETAR (MPP) nas estações de verão e inverno. Letras iguais minúsculas dentro das barras representando à mesma estação (entre áreas) ou maiúsculas fora das barras representando a mesma área (entre estações), não diferem entre si estatisticamente ao nível de 5\% de probabilidade de acordo com o teste de Tukey

Anderson \& Domsch (1993) avaliaram a influência do pH em diversos sítios florestais e verificaram que, em solos ácidos, os valores do quociente metabólico $\left(q \mathrm{CO}_{2}\right)$ apresentavam-se mais elevados. Os autores atribuíram ao quociente metabólico a função de um possível indicador do estresse ambiental, sendo que altos valores refletiriam uma alta demanda de energia da comunidade microbiana para se manter (situação de 
estresse), porém, esse tende a diminuir ao longo do tempo com a recuperação do ambiente.

Os valores encontrados nos ecossistemas avaliados foram baixos, apesar de se tratar de solos ácidos, porém, era esperado, já que foi observado um maior armazenamento de nutrientes pela biomassa microbiana com menos perdas de $\mathrm{C}-\mathrm{CO}_{2}$ para o ambiente (Figuras 21 e 22) indicando que estes ecossistemas estão num estágio mais avançado de sucessão, onde o acúmulo de energia retido no sistema é maior (Anderson \& Domsch, 1990; Insam \& Haselwandter, 1989; Kieft et al.,1998 e Odum, 1983).

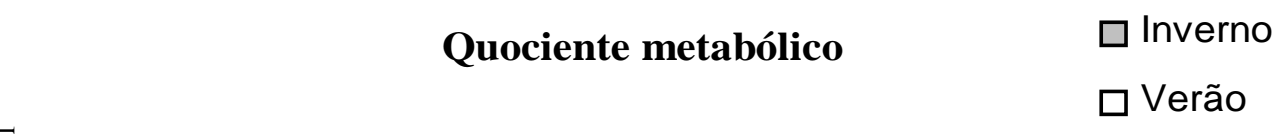

1
0
0
0
00
0
0
0
3
0
0
0
0
2
0

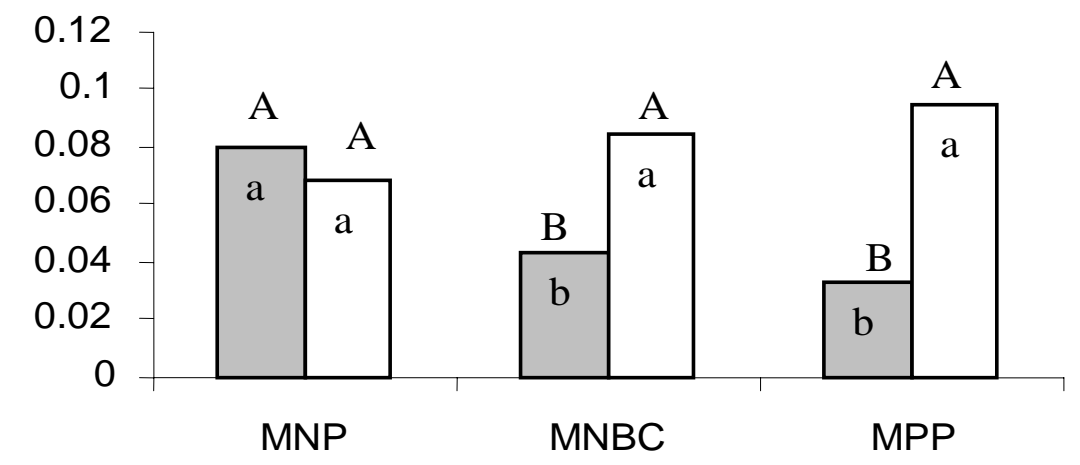

Ecossistemas/PETAR

Figura 21 - Quociente metabólico ( $\mu \mathbf{g} \mathbf{C O}_{2} / \mu \mathbf{g} \mathbf{C} \mathbf{g}^{-1}$ solo $\mathbf{h}^{-1}$ ) nas matas do PETAR: Mata Natural do PETAR (MNP), Mata Natural da Barra do Chapéu (MNBC) e Mata Plantada do PETAR (MPP) nas estações de verão inverno. Letras iguais minúsculas dentro das barras representando à mesma estação (entre áreas) ou maiúsculas fora das barras representando a mesma área (entre estações), não diferem entre si estatisticamente ao nível de 5\% de probabilidade de acordo com o teste de Tukey 


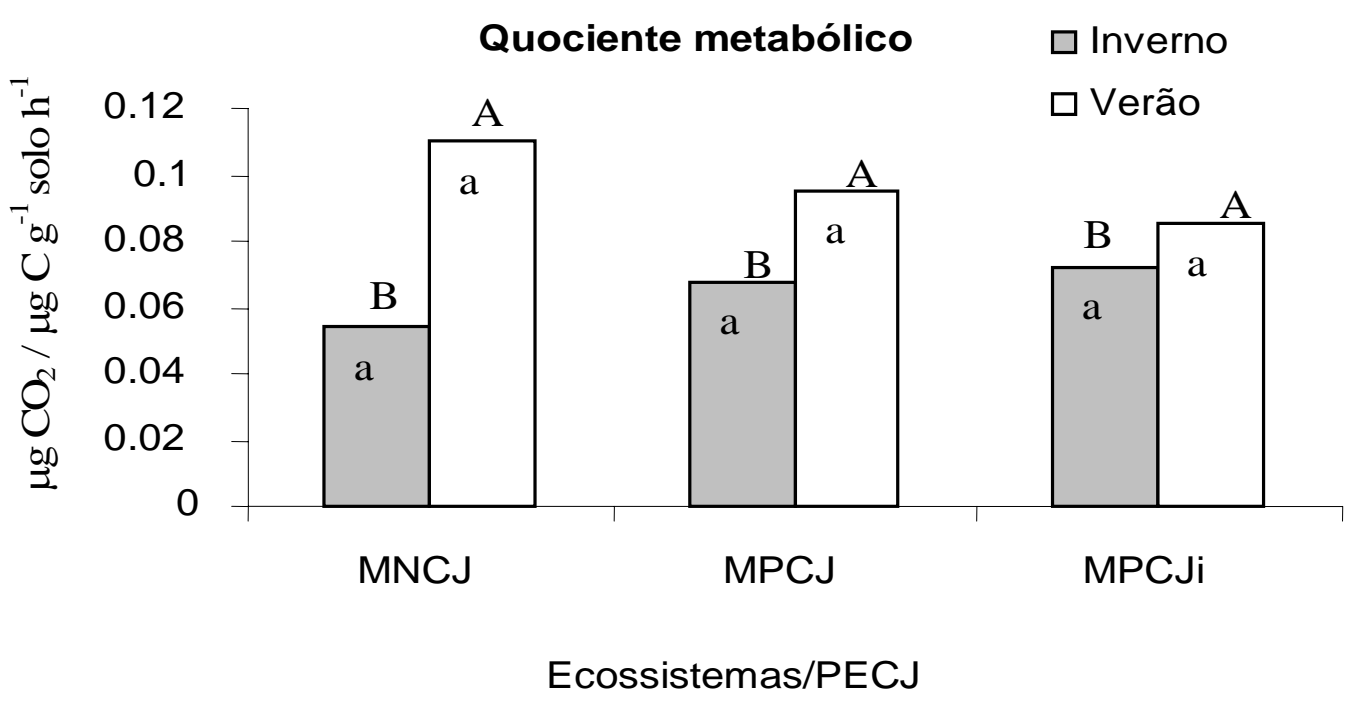

Figura 22 - Quociente metabólico ( $\mu \mathbf{g} \mathbf{C O}_{\mathbf{2}} / \mu \mathbf{g} \mathbf{C} \mathbf{g}^{-\mathbf{1}}$ solo $\mathbf{h}^{-\mathbf{1}}$ ) matas do PECJ: Mata Natural de Campos do Jordão (MNCJ), Mata Plantada de Campos do Jordão (MPCJ) e Mata Plantada de Campos do Jordão com ocorrência de incêndio (MPCJi) nas estações de verão e inverno. Letras iguais minúsculas dentro das barras representando à mesma estação (entre áreas) ou maiúsculas fora das barras representando a mesma área (entre estações), não diferem entre si estatisticamente ao nível de $5 \%$ de probabilidade de acordo com o teste de Tukey

Portanto, vale ressaltar que, apesar das diferenças entre os ecossistemas estudados, a comunidade microbiana de cada um deles estabeleceu um equilíbrio de funcionamento peculiar dentro de suas limitações. Neste caso, é válido o conceito de policlímax, que diz ser improvável que todas as comunidades de uma dada região se desenvolvam por igual quando as condições do hábitat físico não são uniformes e, também, que a comunidade não pode remodelar todos os hábitats até um nível comum dentro de espaço razoável de tempo, medido pela duração da vida de uma pessoa (Odum, 1983).

Mader et al. (2002), avaliando agroecossistemas durante 21 anos, observaram uma alta correlação negativa entre o quociente metabólico e a diversidade microbiana. 
Portanto um $q \mathrm{CO}^{2}$ baixo estaria, pois, correlacionado com uma maior diversidade da comunidade microbiana e uma maior eficiência do uso da energia.

Os ecossistemas que sofreram algum tipo de interferência, representados no presente estudo pelas matas plantadas e impactadas por atividades antrópicas (MNBC, MPP, MPCJ e MPCJi), mostraram-se eficientes na conservação da energia (altos valores de carbono e nitrogênio na biomassa microbiana, com valores baixos de respiração), além de apresentar baixos quocientes metabólicos, sugerindo que estas áreas apresentam, junto com as matas nativas, uma alta diversidade da comunidade microbiana, implicando em uma redundância dos componentes funcionais, contribuindo, assim, para uma maior resiliência destas matas.

\subsubsection{Atividade enzimática}

\subsubsection{Atividade da urease}

A atividade bioquímica total dos solos compreende uma série de reações catalisadas por enzimas, principalmente extracelulares, que podem estar livres na solução do solo, adsorvidas nos colóides ou imobilizadas em complexos húmicos ou, ainda, por enzimas intracelulares que, após a lise das células, podem atuar também como enzimas extracelulares. Todas são produzidas pelos microrganismos, animais e plantas, podendo ser encontradas em vários componentes do solo (Alef \& Nannipieri, 1995; Lynch, 1986 e Moreira \& Siqueira, 2002).

O ciclo do nitrogênio possui relevada importância agrícola, econômica e ecológica, sendo sua principal característica a interação entre as atividades de organismos autotróficos e heterotróficos (Camargo et al., 1999).

O processo de mineralização do solo é resultante da degradação de formas orgânicas do nitrogênio, decorrente da atividade dos microrganismos, portanto, desempenha um papel significativo no ciclo do nitrogênio, sendo responsável pela transformação do $\mathrm{N}$ orgânico presente no tecido vegetal para formas inorgânicas simples. O primeiro processo de transformação do nitrogênio orgânico em mineral é 
denominado amonificação, sendo este considerado limitante no processo de mineralização. Dentre as formas de nitrogênio orgânico encontradas, está a uréia, ocorrendo de forma natural por meio de excreções de animais e como produto de mineralização de ácidos nucléicos.

Através do processo de amonificação a uréia se transformará com o auxílio da enzima urease em amônio que, por sua vez, terá vários destinos, de acordo com as condições ambientais, sendo possível ser imobilizado pelos microrganismos, absorvido pelos vegetais superiores, adsorvidos pelos minerais de argila, além de ser oxidado a nitrato, iniciando assim o processo de nitrificação (Victoria et al., 1992). Dentre os microrganismos que hidrolisam a uréia estão às bactérias, fungos e os actinomicetos (Roberge \& Knowles, 1967). A mineralização do nitrogênio é influenciada pelos fatores que controlam o crescimento e atividade microbiana no solo, como também a qualidade da serapilheira incorporada.

A quantificação da atividade da urease pode nos fornecer uma indicação do potencial do solo em converter nitrogênio orgânico em mineral, dando início ao processo de mineralização do nitrogênio, mas, deve se ter cautela em afirmar quais os processos que podem estar acontecendo, já que estes sofrem diversas influências, como $\mathrm{pH}$, temperatura, quantidade de substrato, além de outros.

Os ecossistemas avaliados não apresentaram para a atividade da urease diferenças significativas com relação à sazonalidade, concordando com Gianfreda \& Bollag (1996) que encontraram uma fraca relação entre a atividade enzimática e as variações estacionais (Figuras 23 e 24).

Os ecossistemas avaliados no PECJ não apresentaram diferença estatística entre áreas, o que pode estar demonstrando que as áreas que sofreram distúrbios (MPCJ e MPCJi) recuperaram sua funcionalidade em relação à mineralização do nitrogênio, mostrando-se, portanto, capazes de converter o nitrogênio orgânico em mineral (Figura 23). 


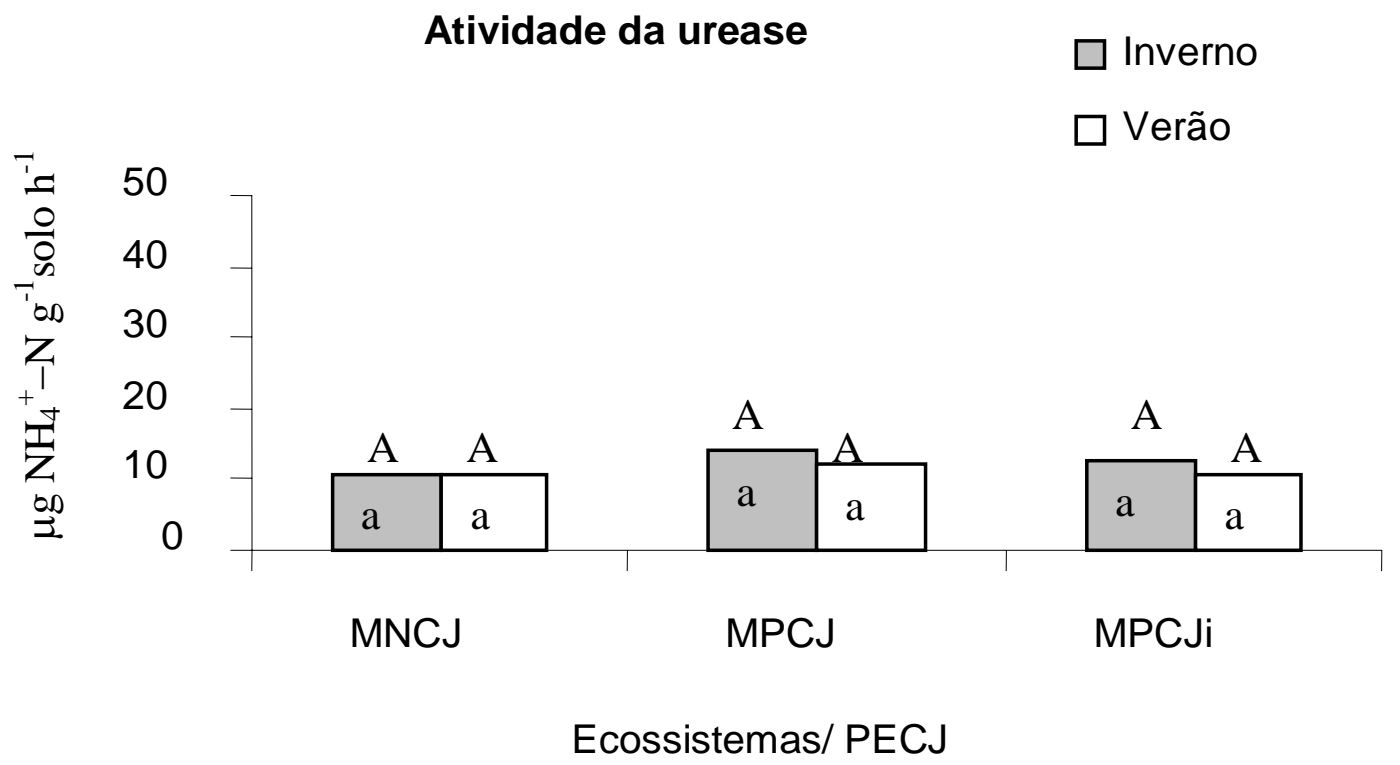

Figura 23- Atividade da enzima urease ( $\mu \mathbf{g} \mathbf{N}-\mathbf{N H}_{\mathbf{4}}{ }^{+} \mathbf{g}^{-1}$ solo $\left.\mathbf{h}^{-1}\right)$ nos ecossistemas matas do PECJ: Mata Natural de Campos do Jordão (MNCJ), Mata Plantada de Campos do Jordão (MPCJ) e Mata Plantada de Campos do Jordão com ocorrência de incêndio (MPCJi) nas estações de verão e inverno. Letras iguais minúsculas dentro das barras representando à mesma estação (entre áreas) ou maiúsculas fora das barras representando a mesma área (entre estações), não diferem entre si estatisticamente ao nível de 5\% de probabilidade de acordo com o teste de Tukey

Os ecossistemas avaliados no PETAR também não apresentaram diferença estatística com relação à sazonalidade, porém apresentaram diferenças significativas entre os ecossistemas avaliados, sendo que a MNP apresentou valores 86\% e 79\% superiores a MPP e valores 62\% e 60\% superiores a MNBC, nas estações de inverno e verão, respectivamente (Figura 24). Porém, é importante ressaltar que os atributos químicos assim como a cobertura vegetal têm grande influência neste processo e, como descrito anteriormente, o ecossistema MNP foi o único a apresentar solo fértil e pH mais próximo da neutralidade, como também uma cobertura vegetal mais diversificada, tornando a serapilheira deste ecossistema mais heterogênia, quando comparada com os 
demais ecossistemas, propiciando melhor fonte de energia para os microrganismos, favorecendo assim, a atividade enzimática (Metting, 1992).

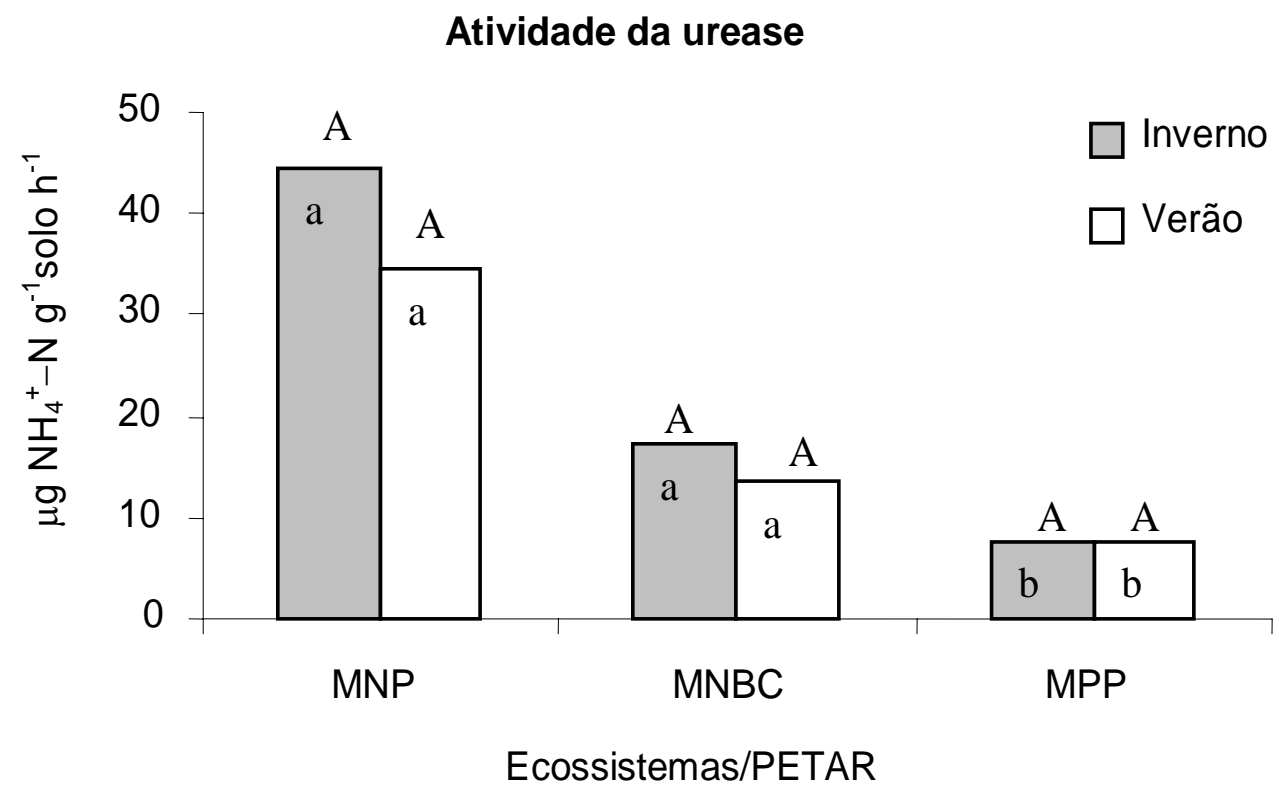

Figura 24 - Atividade da enzima urease ( $\mu \mathbf{g ~ N}-\mathbf{N H}_{4}{ }^{+} \mathbf{g}^{-1}$ solo $\mathbf{h}^{-1}$ ) nos ecossistemas do PETAR: Mata Natural do PETAR (MNP), Mata Natural da Barra do Chapéu (MNBC) e Mata Plantada do PETAR (MPP) nas estações de verão e inverno. Letras iguais minúsculas dentro das barras representando à mesma estação (entre áreas) ou maiúsculas fora das barras representando a mesma área (entre estações), não diferem entre si estatisticamente ao nível de $5 \%$ de probabilidade de acordo com o teste de Tukey

A velocidade da hidrólise da uréia é influenciada pelo tipo de vegetação. A intensidade do efeito da matéria orgânica na atividade da urease dependerá da sua disponibilidade como fonte energética para os microrganismos, ou seja, facilidade de decomposição microbiológica da matéria orgânica, bem como, a quantidade aplicada (Dick, 1984 e Santos \& Camargo, 1999). 
Pôde-se observar que em ecossistemas com predomínio da araucária (MNCJ, MPCJ, MPCJi, MNBC e MPP) a atividade da urease obteve valores próximos, distanciando-se do ecossistema MNP, que apresenta uma vegetação típica de mata atlântica, (mais diversificada).

Tudo indica que o processo de amonificação esteja ocorrendo normalmente nos ecossistemas avaliados, já que as condições químicas do solo estão sendo favoráveis, porém para o processo de nitrificação, a situação é contrária, já que estes solos apresentam baixos valores de $\mathrm{pH}$. Este fato favorece encontrar altos teores de amônio nestes ecossistemas, já que o processo de nitrificação é altamente influenciado pelo $\mathrm{pH}$, assim como os microrganismos responsáveis por este processo, que necessitam de um pH na faixa de 7,0 a 7,6 para atingir seu crescimento ideal. Outro fator que pode estar atuando na inibição da nitrificação é a alta relação C/N encontrada nos ecossistemas, pois, devido à imobilização do nitrogênio mineral, ocorre a falta de substrato $\left(\mathrm{NH}_{4}{ }^{+}\right)$. È provável que nestes ecossistemas as perdas de nitrogênio por lixiviação e até mesmo por meio da desnitrificação sejam diminutas já que ocorre uma inibição natural da conversão de amônio para as formas de nitrato e nitrito. O amônio é um cátion que pode ser adsorvido aos colóides do solo, tornando-o relativamente estacionário, contribuindo ainda mais para a manutenção do nitrogênio no solo.

\subsubsection{Hidrólise do diacetato de fluoresceína - FDA}

A hidrólise da FDA é usada como indicador geral da atividade hidrolítica, incluindo proteases, lipases e esterases que também são capazes de clivar compostos fluorogênicos (Taylor et al., 2002). Desta forma, essa ação catalítica pode ser considerada uma medida da atividade microbiana total, embora as enzimas envolvidas nesta reação apresentem atividade externa à célula, podendo se encontrar complexadas com os colóides do solo (Swisher \& Carroll, 1980). Em particular, a atividade enzimática no solo proporciona catálise de inúmeras reações necessárias ao ciclo de vida dos microrganismos, na decomposição de resíduos orgânicos durante o ciclo de nutrientes e na formação da matéria orgânica e estrutura do solo (Burns, 1978), onde a 
presença da cobertura vegetal é um importante fator na qualidade do solo, pelo fornecimento de fontes de energia necessárias à manutenção da população microbiana no solo (Pascual et al., 2000).

Os ecossistemas avaliados não apresentaram diferença estatística com relação à sazonalidade, o que também e foi observado por Gianfreda \& Bollag (1996), que encontraram uma fraca relação entre a atividade enzimática e as variações estacionais. Para os ecossistemas do PETAR e PECJ não houve diferenças significativas entre áreas, demonstrando que nestes ecossistemas o potencial da atividade total dos decompositores é equivalente (Figuras 25 e 26).

Hidrólise do diacetato de fluoresceína ।

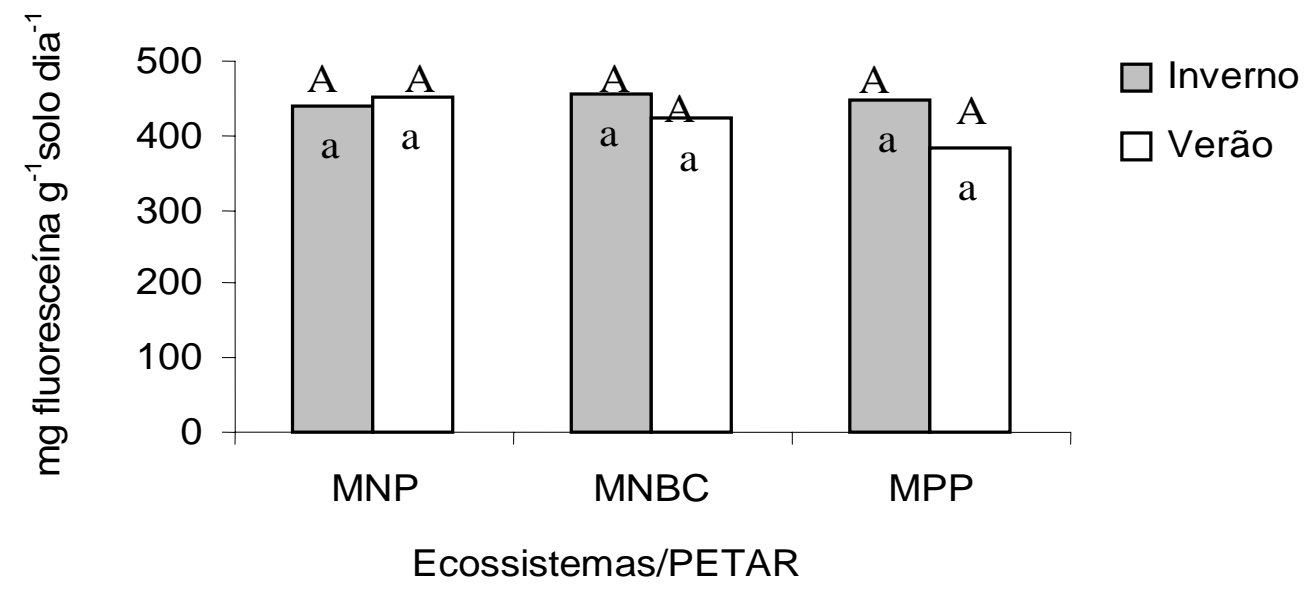

Figura 25 - Hidrólise do diacetato de fluoresceína (FDA - mg fluoresceína g $^{-1}$ solo dia $^{-1}$ ) nos ecossistemas do PETAR: Mata Natural do PETAR (MNP), Mata Natural da Barra do Chapéu (MNBC) e Mata Plantada do PETAR (MPP) nas estações de verão e inverno. Letras iguais minúsculas dentro das barras representando a mesma estação (entre áreas) ou maiúsculas fora das barras representando a mesma área (entre estações), não diferem entre si estatisticamente ao nível de 5\% de probabilidade de acordo com o teste de Tukey 
Hidrólise do diacetato de fluoresceína $\quad \square$ Inverno

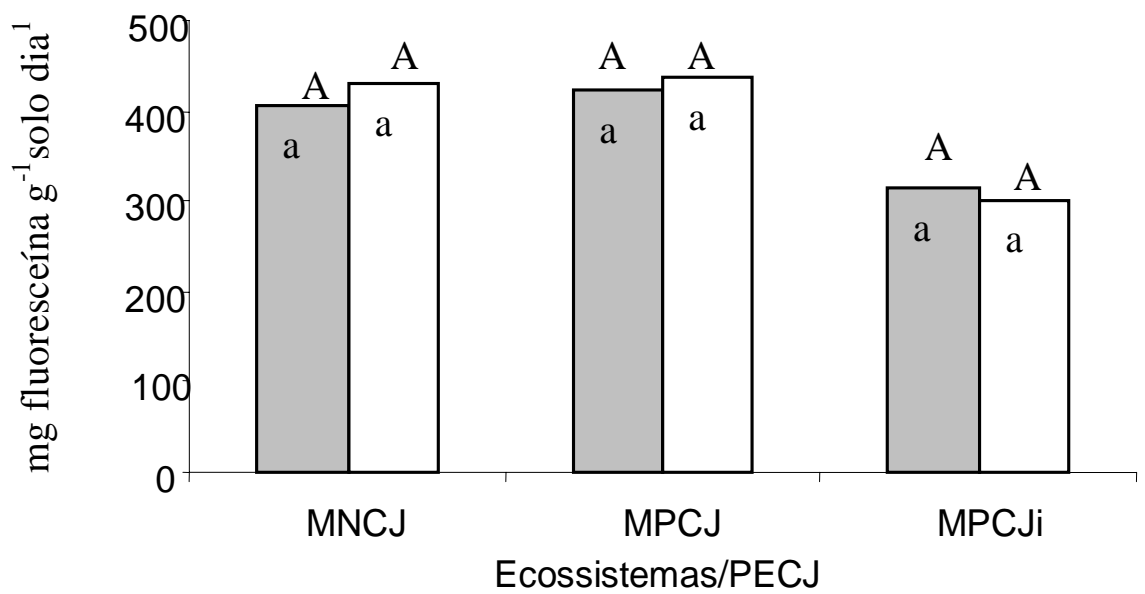

Figura 26 - Hidrólise do diacetato de fluoresceína (FDA) (mg fluoresceína g $^{-1}$ solo dia $^{1}$ ) nos ecossistemas matas do PECJ: Mata Natural de Campos do Jordão (MNCJ), Mata Plantada de Campos do Jordão (MPCJ) e Mata Plantada de Campos do Jordão com ocorrência de incêndio (MPCJi) nas estações de verão e inverno. Letras iguais minúsculas dentro das barras representando à mesma estação (entre áreas) ou maiúsculas fora das barras representando a mesma área (entre estações), não diferem entre si estatisticamente ao nível de $5 \%$ de probabilidade de acordo com o teste de Tukey

A alta atividade heterotrófica é esperada em solos de mata, pois esta apresenta grande deposição de material orgânico no solo servindo de fonte de nutrientes para os microrganismos. Os ecossistemas avaliados apresentaram altos teores de matéria orgânica, porém com relação C:N alta sugerindo processos de decomposição mais lento. Como foram observados altos valores para a hidrólise do diacetato de fluoresceína, os ecossistemas avaliados podem estar recebendo uma contribuição da rizosfera por meio 
da liberação de exsudados (principalmente glicose) que por sua vez servirá de fonte de nutriente para o desenvolvimento dos microrganismos.

A FDA tem sido correlacionada positivamente com a respiração do solo (Schnüner \& Rosswal, 1982), porém, por meio da respiração basal, os ecossistemas avaliados não demonstraram alta atividade heterotrófica. Estes dados reforçam que estes ecossistemas são capazes de conservar energia (menos perdas de $\mathrm{C}_{-} \mathrm{CO}_{2}$ e maior acúmulo de $\mathrm{C}$ e $\mathrm{N}$ na biomassa microbiana), sugerindo que estes se encontram num estádio mais avançado de sucessão.

Observou-se que as diferenças ocorridas na caracterização química do solo, principalmente entre os ecossistemas do PETAR, não ocasionaram diferenças significativas no potencial da hidrólise do diacetato de fluoresceína. Sabe-se que a liberação de enzimas capazes de realizar esta hidrólise é feita por diversos microrganismos (fungos, bactérias, protozoários, entre outros), esta diversidade contribui para manter a funcionalidade do sistema mesmo em condições adversas (solos ácidos e pobres), tornando estes ambientes com uma maior capacidade de resiliência.

\subsubsection{Atividade da $\beta$-glicosidase}

As enzimas têm participação essencial nos ciclos dos elementos no solo e como são sintetizadas principalmente pelos organismos que nele crescem as condições que favorecem a atividade microbiana, como presença de vegetação (rizosfera), também favorece a atividade enzimática. Eivazi \& Tabatabai (1988) descrevem que a atividade da $\beta$-glicosidase possui correlação significativa com a matéria orgânica do solo e atua tanto na hidrólise da celobiose como também de oligossacarídeos liberando açúcar (glicose) que servirá como fonte de energia para os microrganismos.

De modo geral, os dados obtidos demonstram ecossistemas com alto potencial da atividade da $\beta$-glicosidase, e não foi observada diferença estatística entre as estações (inverno e verão) avaliadas (Figuras 27 e 28). 
Os ecossistemas MNP, MNBC e MPP não apresentaram diferenças estatísticas entre si, demonstrando o mesmo potencial para a atividade da $\beta$-glicosidase. Este alto potencial encontrado deve estar relacionado com o alto teor de material orgânico encontrado nestes ecossistemas, além da contribuição da rizosfera por meio da liberação de oligossacarídeos. A alta atividade desta enzima indica que nestes ecossistemas existe material facilmente decomposto que servirá como fonte de nutrientes para a comunidade microbiana que por sua vez torná-los-á disponíveis para as plantas por meio da mineralização (Figura 27).

Atividade da enzima $\beta$-glicosidase

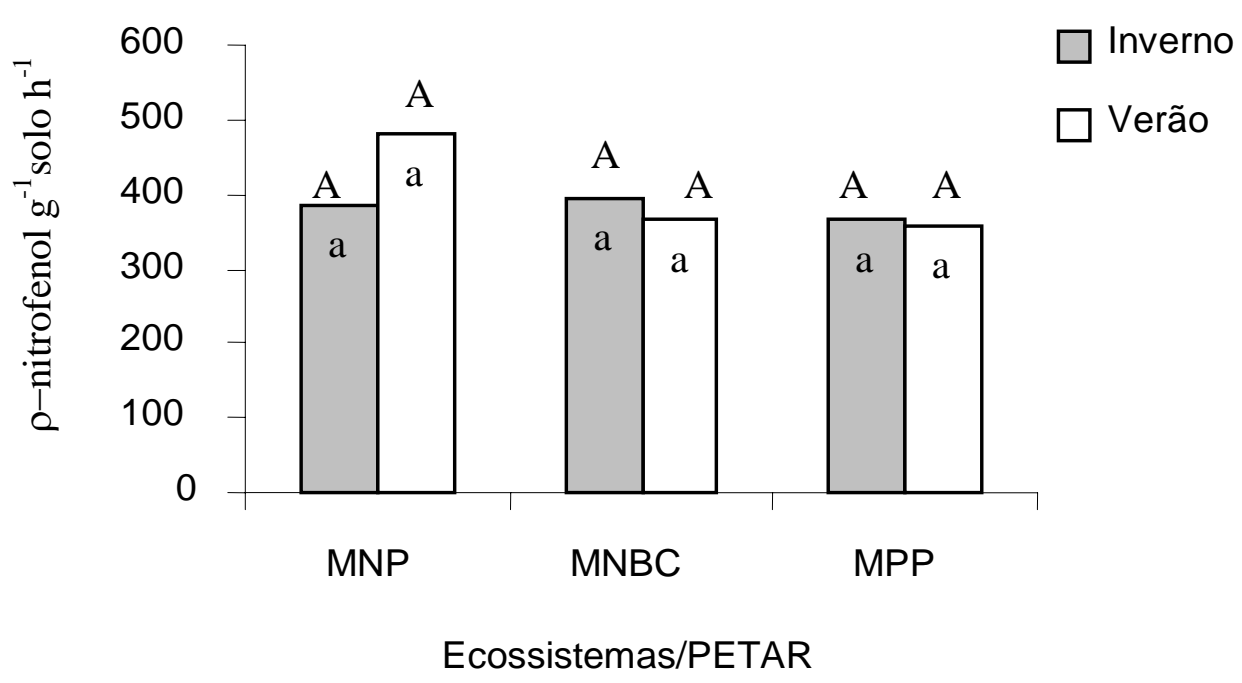

Figura 27 - Atividade da enzima $\beta$-glicosidase $\left(\rho\right.$-nitrofenol $\mathbf{g}^{-\mathbf{1}}$ solo $\left.\mathbf{h}^{\mathbf{- 1}}\right)$ nos ecossistemas do PETAR: Mata Natural do PETAR (MNP), Mata Natural da Barra do Chapéu (MNBC) e Mata Plantada do PETAR (MPP) nas estações de verão e inverno. Letras iguais minúsculas dentro das barras representando a mesma estação (entre áreas) ou maiúsculas fora das barras representando a mesma área (entre estações), não diferem entre si estatisticamente ao nível de 5\% de probabilidade de acordo com o teste de Tukey 
Os dados obtidos para os ecossistemas do PECJ apresentaram diferença estatística para o verão, onde a MPCJi apresentou menor potencial para a atividade da enzima. Esta redução do potencial pode estar relacionada com os menores teores de matéria orgânica e carbono orgânico encontrados neste solo. Apesar deste ecossistema apresentar um menor potencial, deve-se lembrar que o tipo de solo é diferente (Cambissolo Háplico) e que as diferenças encontradas entre os ecossistemas avaliados não necessariamente demonstram ambientes estressados, mais sim limitados por suas condições físico-químicos (Figura 28).

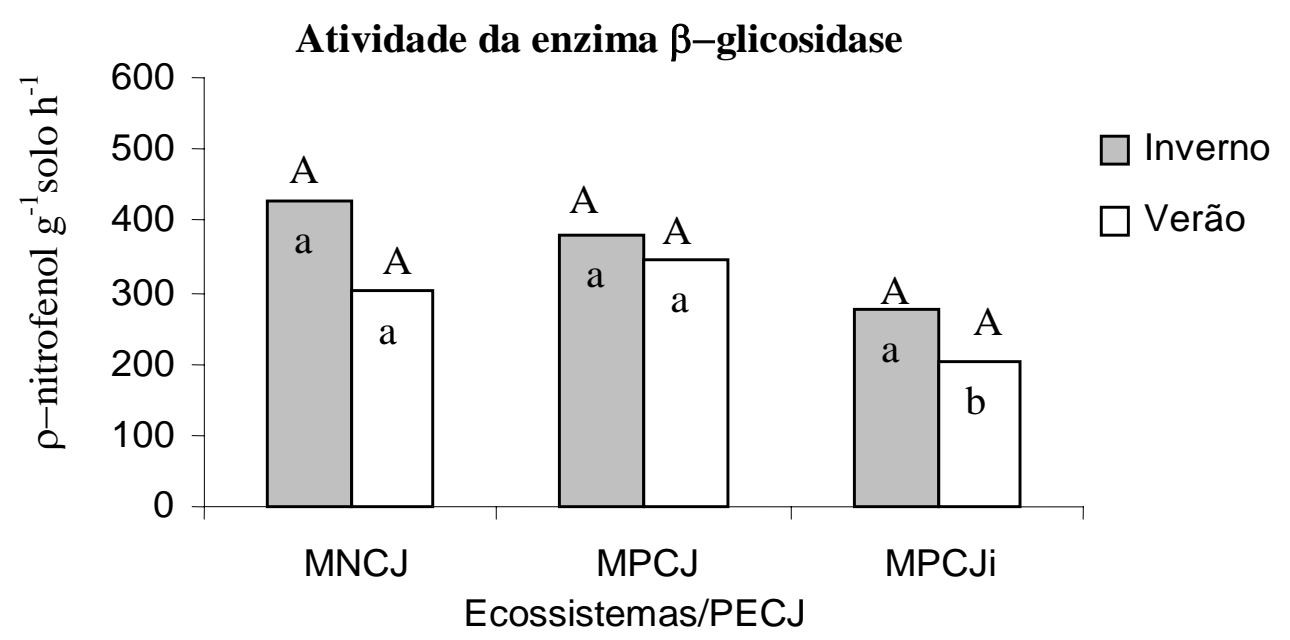

Figura 28 - Atividade da enzima $\beta$-glicosidase $\left(\rho\right.$-nitrofenol $\mathbf{g}^{-1}$ solo $\mathbf{h}^{-\mathbf{1}}$ ) nos ecossistemas do PECJ: Mata Natural de Campos do Jordão (MNCJ), Mata Plantada de Campos do Jordão (MPCJ) e Mata Plantada de Campos do Jordão com ocorrência de incêndio (MPCJi) nas estações de verão e inverno. Letras iguais minúsculas dentro das barras representando a mesma estação (entre áreas) ou maiúsculas fora das barras representando a mesma área (entre estações), não diferem entre si estatisticamente ao nível de $5 \%$ de probabilidade de acordo com o teste de Tukey 


\section{CONCLUSÕES}

Os valores isolados de carbono e nitrogênio da biomassa microbiana não foram eficientes em indicar alterações ocorridas nos ecossistemas.

A respiração basal e o quociente metabólico associados ao carbono e nitrogênio da biomassa constituem um bom indicador da funcionalidade do sistema, portanto um bom indicador da qualidade do solo.

As atividades enzimáticas (FDA, urease e $\beta$-glicosidase) serviram como indicadoras do potencial da funcionalidade dos ecossistemas e, aliadas aos demais atributos biológicos, tornaram-se boas indicadoras da qualidade do solo.

Mesmo tendo observado diferenças nos atributos avaliados, os ecossistemas envolvidos no presente estudo mostraram-se eficientes no uso e na conservação de energia, sugerindo que se encontram em um estádio mais avançado de sucessão.

As características do solo aliadas à cobertura vegetal (rizosfera) e clima, desempenharam grande influência nas diferenças ocorridas entre os ecossistemas. 


\section{REFERÊNCIAS BIBLIOGRÁFICAS}

ALCÂNTARA, R.M.C.M. Propriedades químicas e bioquímicas e suas inter-relações em solos sob vegetação de mata e campo adjacentes. Lavras, 1995. 84p. Dissertação (Mestrado) - Universidade Federal de Lavras.

ALEF, K.; NANNIPIERI, P. (Ed.). Methods in applied soil microbiology and biochemistry. London: Academic Press, 1995. 576p.

ANDERSON, T.H.; DOMSCH, K.H. Application of eco-physiological quotients $\left(q \mathrm{CO}_{2}\right.$ and $q \mathrm{D}$ ) on microbial biomasses from soils of different cropping histories. Soil Biology \& Biochemistry, v.22, p. 251-255, 1990.

ANDERSON, T.H.; DOMSCH, K.H. The metabolic quotient for $\mathrm{CO}_{2}\left(q \mathrm{CO}_{2}\right)$ as a specific activity parameter to assess the effects of environmental conditions, such $\mathrm{pH}$, on the microbial biomass of forest soils. Soil Biology and Biochemistry, v.25, p.393-395, 1993.

ANGERS, D.A.; BISSONNETTE, N.; LÈGÉRE, A.; SAMSOM, N. Microbial and biochemical changes induced by rotation and tillage in a soil under barley production. Canadian Journal of Soil Science, v.73 p.39-50, 1993.

AZEVEDO, O. Os pinheiros do Brasil. Informação Florestal, v.6, p.15-8, jul./set.1994

BRADY, N.C. Natureza e propriedades de solos. Rio de Janeiro: Freitas Bastos, 1989. 878p. 
BRANDÃO, E.M. Os componentes da comunidade microbiana do solo. In: CARDOSO, E.J.B.N.; TSAI, S.M.; NEVES, M.C. Microbiologia do solo. Campinas: Sociedade Brasileira de Ciência do Solo. Cap. 1, p.1-15, 1992.

BRAGAGNOLO, N. Efeito da cobertura do solo por resíduos de culturas sobre a temperatura e umidade do solo, germinação e crescimento do milho. Porto Alegre, 1986. 119p. Dissertação (Mestrado)- Faculdade de Agronomia, Universidade Federal do Rio Grande do Sul.

BRASIL. Ministério da Agricultura. Instituto Brasileiro do Meio Ambiente e dos Recursos Naturais Renováveis. Lista oficial de espécies da flora brasileira ameaçadas de extinção p. 870-872: Portaria nº 06, de 23 de janeiro de 1992.

BROOKES, P.C. The use of microbial parameters in monitoring soil pollution by heavy metals. Biology and Fertility of Soils, v.19, n.4, p. 269-279, 1995.

BURNS, R.G. Soil enzymes. New York: Academic Press, 1978. 379p.

BURNS, R.G. Interaction of enzymes with soil mineral and organic colloids. In: HUANG, P.M.; SCHNITZER, M. (Ed.). Interactions of soils minerals with natural organics and microbes. Madison: Soil Science Society of America, 1986. p. $429-451$

CABRAL, L.; ZENI, I.M.; ALMEIDA, D.; FILHO, O.K.; BRANCO, G.C.; MOTA.E.C. C-microbiano em solo de campo nativo mata nativa de araucária e reflorestamento de pinus e araucária no planalto serrano catarinense (compact disc). In: FERTIBIO, Lages, 2004. Campinas:SBCS, 2004.

CAMARGO, O. A. de; MONIZ, A.C.; JORGE, J.A.; VALADARES, J.M.A.S. Métodos de análise química, mineralógica e física de solos do Instituto Agronômico de Campinas. Campinas: Instituto Agronômico, 94p. 1986. (IAC, Boletim Técnico, 106). 
CAMPBELL, C.A.; BIEDERBCK, V.O. Soil bacterial changes as affected by growing season weather conditions: a field and laboratory study. Canadian Journal of Soil Science, v. 56, p.293-310, 1976.

CAMPOS, D.C. Influência da mudança do uso da terra sobre a matéria orgânica no município de São Pedro-SP. Piracicaba, 1998. 83p. Dissertação (Mestrado) - Escola Superior de Agricultura Luiz de Queiroz, Universidade de São Paulo.

CARDOSO, E.J.B.N; FREITAS, S.S. A rizosfera. In: CARDOSO, E.J.B.N.; TSAI, S.M.; NEVES, M.C. Microbiologia do solo. Campinas: SBCS, 1992. cap. 4, p.4158. 1992.

CARNEIRO, M.A.C. Características bioquímicas do solo em duas cronossequências de reabilitação em áreas de mineração de bauxita. Lavras, 2000. 166p. Tese (Doutorado) - Universidade Federal de Lavras.

CATTELAN, A.J.; VIDOR, C. Flutuações na biomassa, atividade e população microbiana do solo, em função de variações ambientais. Revista Brasileira de Ciência do Solo, v.14 p.133-142, 1990.

CERRI, C.C.; VOLKOFF, B.; EDUARDO, B.P. Efeito do desmatamento sobre a biomassa microbiana em Latossolo Amarelo da Amazônia. Revista Brasileira de Ciência do Solo, v.9, n.1, p.1-4, jan./abr. 1985.

CHANDER, K.; BROOKES, P.C. Residual effects of zinc, copper and nickel in sewage sludge on microbial biomass in a sandy loam. Soil Biology and Biochemistry, v.25, n.9, p. 1231-1239, 1993.

CORREIA, M.E.F.; ANDRADE, A.G. Formação da serapilheira e ciclagem de nutrientes. SANTOS, G.A.; CAMARGO, F.A.O. (Ed.). Fundamentos da matéria orgânica do solo: ecossistemas tropicais e subtropicais. Porto Alegre: Gênesis, 1999, p.197-225. 
D’ANDREA, A.F.; SILVA, M.L.N.; CURI, N.; SIQUEIRA, J.O.; CARNEIRO, M.A.C. Atributos biológicos indicadores da qualidade do solo em diferentes sistemas de manejo do solo na região do cerrado no sul do estado de Goiás. Revista Brasileira de Ciência do Solo, v.26, p.913-923, 2002.

DE-POLLI, H.; GUERRA, J.G.M. Biomassa microbiana: perspectivas para o uso e manejo do solo. In: ALVAREZ, V.; FONTES, V.H.; FONTES, M.P.F. (Ed.). O solo nos grande domínios morfoclimáticos do Brasil e o desenvolvimento sustentado. Viçosa: Sociedade Brasileira de Ciência do Solo, 1996. p.551-64.

DIACK, M. Relationships between soil biological and chemical characteristics and surface soil structural properties for use in soil quality. Purdue. 221p. 1997. Tese (Doutorado) - Purdue University

DICK, R.P. Soil enzyme activities as indicators of soil quality. In: DORAN, J. W.; COLEMAN, D.C.; BEZDICEK, D.F.; STEWART, B.A. (Ed.). Defining soil quality for a sustainable environment. Madison: American Society of Agronomy, 1994. p.107-124.

DORAN, J.W.; SARRANTONIO, M.; LIEBIG, M.A. Soil health and sustainability. Advances in Agronomy, v.56, p. 2-54, 1996.

DORAN, J.W. Soil quality and sustainability. In: CONGRESSO BRASILEIRO DE CIÊNCIA DO SOLO, 26. Rio de Janeiro, 1997. Rio de Janeiro: Comissão do "V Inventory. Gênesis, Morphology and Classification of Soils. 1997. p.

DORAN, J.W.; ZEISS, M.R. Soil health and sustainability: managing the biotic component of soil quality. Applied Soil Ecology, v. 15, n.1, p. 3-11, Aug. 2000.

DUMANSKI, J.; PIERI, C. Land quality indicators: research plan. Agriculture, Ecosystems \& Environment, v. 81, p.155-162, 2000. 
EIVAZI, F.; TABATABAI, M.A. Glucosidases and galactosidases in soils. Soil Biology and Biochemistry, v.20, n.5, p. 601-606, 1988.

EVANS, D.G.; MILLER, M.H. Vesicular-arbuscular mycorrizas and the soil disturbance-indeced of nutrient absortion in maize: I. Casual relations. New Phytologist, v.110, p.67-74, 1988.

EVANS, D.G.; MILLER, M.H. The role of external mycelial network in the effect of soil disturbance upon vesicular-arbuscular mycorrhizal colonization of maize. New Phytologist, v.114, .p.65-71, 1990.

FEIGL, B.J.; SPARLING, G P.; ROSS, D.J.; CERRI, C.C. Soil microbial biomass in Amazonian soils: Evaluation of methods and estimates of pool sizes. Soil Biology and Biochemistry, v.27, n.11, p.1467-1472, 1995.

GAMA-RODRIGUES, E.F.; GAMA-RODRIGUES, A.C.; BARROS, N.F. Biomassa microbiana de carbono e de nitrogênio de solos sob diferentes coberturas florestais. Revista Brasileira de Ciência do Solo, v. 21, p.361-365, 1997.

GIANFREDA, L.; BOLLAG, J.M. Influence of nature and anthropogenic factors on enzyme activity in soil. In: STOTZKY, G.; BOLLAG, J.M. (Ed.). Soil Biochemyistry, v.9, p.122-194, 1996.

GOLFARI, L. Coníferas aptas para repoblaciones florestales en el Estado de São Paulo. Silvicultura em São Paulo, n.6, p.7-62, 1967.

GONZALEZ, M.I.M.; GALLARDO, J.F. El efecto hojarasca: una revision. Anales de Edafologia y Agrobiologia, v.41 n.5/6, p.1129-1157, 1982.

GUPTA, V.V.S.R.; GERMIDA, J. Distribution of microbial biomass and its activity in different soil aggregate size classes as affected by cultivation. Soil Biology and Biochemistry, v.20, p.777-786, 1998. 
HAAG, H.P. Ciclagem de nutrientes em florestas tropicais. Campinas: Fundação Cargil, 1985. 114p.

HERRERA, R.; JORDAN, C.F.; KLINGE, H.; MEDINA, E. Amazon ecosystems. Their structure and functioning with particular emphasis on nutrients. Interciência, v.3 , n.4, p. 223-32, 1978.

HUECK, K. As florestas da América do Sul. São Paulo: Polígono, 1972. p. 206-239.

INSAM, H.; DOMSCH, K.H. Relationship between soil organic carbon and microbial biomass on chronosequenses of reclamation sites. Microbial Ecology, v.15, p.177188, 1988.

INSAM, H.; HASELWANDTER, K. Metabolic quotient of the soil microflora in relation to plant sucession. Oecologia, v.79, p.171-178, 1989.

JASPER, D.A.; ABBOT, L.K.; ROBSON, A.D. Soil disturbance reduces the infectivity of external hyphae of vesicular-arbuscular mycorrhizal fungi. New Phytologist, v.112 p.93-99, 1989.

JENKINSON, D. S.; LADD, J.N. Microbial biomass in soil measurement and turnover. Soil Biology and Biochemistry, v.5/6, p. 415-471, 1981.

JOERGENSEN, R.G. Quantification of the microbial biomass by determining ninhydrin-reactive N. Soil Biology and Biochemistry, v.28, n.3, p. 301-306, 1996.

JOERGENSEN, R.G.; BROOKES, P.C. Ninhydrin-reactive nitrogen measurements of microbial biomass in 0.5M K $\mathrm{SO}_{4}$ soil. Soil Biology and Biochemistry, v.22, n.8, p.1023-1027, 1990.

KARLEN. D.L.; WOLLWNHAUPT, N.C.; ERBACH, D.C.; BERRY, E. C.; SWAN, J.B.; EASH, N.S.; JORDAHL, J.L. Crop residue effects on soil quality following 10-years of no-till com. Soil Tillage Residue, v.31 p.149-167, 1994. 
KENNEDY, A C. Microbial Diversity in Agroecosystem Quality. In: COLLINS, W. W.; QUALSET, C. O. Biodiversity in agroecosystems. New York: CRC, 1998. cap. 1, p.1-17.

KENNEDY, A.C.; SMITH, K.L. Soil microbial diversity and sustainability of agrigultural soils. Plant and Soil, v.170, p. 75-86, 1995.

KIEFT, T.L.; SOROKER, E.; FIRESTONE, M.K. Microbial biomass response to a rapid increase in water potencial when dry soil is wetted. Soil Biology and Biochemistry, v.19, p.119-126, 1987.

KLEIN, R.M. O aspecto dinâmico do pinheiro brasileiro. Sellowia, v.12, p.17-44, 1960.

KOCH. Z.; CORREA. M.C. Araucária a Floresta do Brasil Meridional. Curitiba: Olhar Brasileiro, 2002. 145p.

LEITA, L.; DE NOBILE, M.; MUHLBACHOVA, G.; MONDONI, C.; MARCHIOL, L.; ZERBI, G. Bioavailability and effects of heavy metals on soil microbial biomass survival during laboratory incubation. Biology and Fertility of Soils, v.19, n.2-3, p. 103-108, 1995.

LYNCH, J. M. Biotecnologia do solo: fatores agrobiológicos na produtividade agrícola. São Paulo: Manole, 1986. 209p.

LOBO, D.H. Araucária: necessidade de conservação e recomposição da araucária. Florestar Estatístico, v.6, n.14, p.10-11, jan. 2003.

LOPES, A. S.; GUILHERME, L.R.G. Interpretação de análise do solo: conceitos e aplicações. São Paulo: ANDA, 1992. 37p. (Boletim técnico n²).

LORENZI, H. Árvores brasileiras: manual de identificação e cultivo de plantas arbóreas nativas do Brasil. São Paulo: Plantarum, 1992. 351 p.

MADER, P.; FLIEßBACH, A.; DUBOIS, D.; GUNST, L.; FRIED, P.; NIGGLI, U. Soil fertility and biodiversity in organic farming. Science, v.296, p.4, 2002. 
MAIOR, D.S. Rio protege espécies ameaçadas. Jornal do Brasil, 28 de maio 1997. Cidade, p.18, c.1-5.

MARCHIORI-JUNIOR, M.; MELO, W.J. Alterações na matéria orgânica e na biomassa microbiana em solo de mata natural submetido a diferentes manejos. Pesquisa Agropecuária Brasileira, v.35, n.6, p.1177-1182, jun. 2000.

MARTINEZ, A.T.; RAMIREZ, C. Microfungal biomass and number of propagules in na andosol. Soil Biology and. Biochemistry, v.10, p.529-531, 1978.

MARX, D.H.; CORDELL, C.E.; KENNEY, D.S.; MEXAL, J.D.; ARTMAN, J.D.; RIFFLE, J.W.; MOLINA, R.J. Commercial vegetative inoculum of Pisolithus tinctorius and inoculation tecniques for development of ectomycorrhizae on bareroot tree seedlings. Forest Science, v.30, p.1-101, 1984.

MATSUOKA, M.; MENDES, I.C.; LOUREIRO, M.F. biomassa microbiana e atividade enzimática em solos sob vegetação nativa e sistemas agrícolas anuais e perenes na região de Primavera do Leste (MT). Revista Brasileira de Ciência do. Solo, v.27 n.3, p. 425-433, maio/jun. 2003.

MATTOS, J.R. O pinheiro brasileiro. Curitiba: Grêmio Politécnico, 1972. 648p.

MATTOS, J.R. O pinheiro brasileiro. Lages, Artes Gráfica Princesa Ltda, 1994. 223 p.

McGONIGLE,T.P.; EVANS, D.G.; MILLER, M.H. Effect of degree of soil disturbance on mycorrhizal colonization and phosphorus absortion by maize in growth chamber and field experiments. New Phytologist, v.116, p.629-639, 1990.

MELLO, J.W. Enzimas no solo. In: A responsabilidade social da ciência do solo. Campinas: SBCS, 1988. p. 365-378.

MELLONI, R; PEREIRA, E.G.; TRANNIN, I.C.B.; SANTOS, D.R.; MOREIRA, F.; SIQUEIRA, J.O. Características biológicas de solos sob mata ciliar e campo cerrado no sul de Minas Gerais. Ciência e Agrotecnologia, v.25, n.1, p.7-13, jan.fev. 2001. 
METTING JR. F.B. Soil microbial ecology: Applications in agricultural and environmental management. New York: Marcel Dekker, 1992. 646p.

MOREIRA, F.M.S; SIQUEIRA, J.O. Microbiologia e bioquímica do solo. Lavras: UFLA, 2002. 625p.

ODUM, E.P. Ecologia. Rio de Janeiro: Guanabara 1983. 434p.

OLIVEIRA, J.R.A.; MENDES, I.C.; VIVALD, L. Carbono da biomassa microbiana em solos de cerrado sob vegetação nativa e sob cultivo: Avaliação dos métodos fumigação-incubação e fumigação-extração. Revista Brasileira de Ciência do Solo, v.25, p.863-871, 2001.

ORJUELA, H.B. El suelo: uma vision sobre sus componentes biorgánicos. Pasto: Universidad de Marinõ, 1989 447p.

PARKIN, T.B.; DORAN, J.W.; FRANCO- VIZCAÍNO, E. Field and laboratory tests of soil respiration. In: DORAN, J.W.; JONES, A., (Ed.). Methods for assessisng soil quality. Madison: Soil Science Society of América, 1996. p. 231-245.

PASCUAL, J.A.; GARCIA, C.; HERNANDEZ, T.; MORENO, J.L.; ROS, M. Soil microbial activity as a biomarker of degradation and remediation process. Soil Biology and Biochemistry, v.32, p.1877-1883, 2000.

PFENNING, L.; EDUARDO, B.P.; CERRI, C.C. Os métodos de fumigação-incubação e fumigação-extração na estimativa da biomassa microbiana em solos da Amazônia. Revista Brasileira de Ciência do Solo, v.16, n.1, p.31-37, jan./abr. 1992.

POWLSON, D.S., BROOKES, P.C., CHRISTENSEN, B.T. Measurement of soil microbial biomass provides na indication of changes in total soil organic matter due to straw incorporation. Soil Biololgy and Biochemistry, v.19, n.2, p.159-164, 1987. 
RAIJ, B. VAN; QUAGGIO, J. A.; CANTARELlA, H.; ANDRADE, J. C. Análise química para avaliação da fertilidade de solos tropicais. Campinas: Instituto Agronômico. 2001. 284p.

REBER. H.H. Simultaneous estimates of the diversity and degradative capability of heavy-metal-affected soil bacterial communities. Biology and Fertility of Soils, v.13, p. 181-186, 1992.

REITZ, R.; KLEIN, R. M.; REIS, A. Projeto Madeira do Rio Grande do Sul. Porto Alegre: Companhia Rio Grandense de Artes Gráficas, 1983. 525p.

ROBERGE,M.R.; KNOWLES, R. The ureolityc microflora in a black spruce (Picea mariana Mill) humus. Soil Science Society American Procedings, v.31, p.76-79, 1967.

ROVIRA, A. D. Microbiology of pasture soil and some effects of microorganisms on pasture plants. In: WILSON, J. R. (Ed.). Plant relations in pastures. Melbourne: CSIRO, 1978. p.95-110.

RYAN, P.J.; MCGARITY, J.W. The nature and spatial variability of soil properties adjacent to large forest Eucalyptus. Soil Science Society of America Journal, v.47, n.2, p.286-292, Mar./Apr.1983.

SAS INSTITUTE.SAS/STAT: users guide, release 6.03. SAS Institute Inc., Cary, 1988.

SANTOS, G.A.; CAMARGO, F.A.O. (Ed.). Fundamentos da matéria orgânica do solo:ecossistemas tropicais e subtropicais. Porto Alegre: Gênesis, 1999. 491p.

SCHNEIDER, P.R.; FINGER, C.A.G.; HOPPE, J.M. Produção da Araucaria angustifolia (Bert.) O. Ktze. Na região do planalto médio do estado do Rio Grande do Sul. Ciência Florestal, v.2, n.1, p.99-118, nov.1992. 
SCHNÜNER, J.; ROSSWALL, T. Fluorescein diacetate hydrolysis as a measure of total microbial activity in soil and litter. Applied and Environmental Microbiology, Washighton, v.43, p.1256-1261, 1982

SEIBERT, P. Plano de manejo do Parque Estadual de Campos do Jordão. São Paulo: Instituto Florestal, 1975. 148 p. (Boletim Técnico, 19).

SIMÕES, L.; LINO. C.F. Sustentável mata atlântica : a exploração de seus recursos florestais. São Paulo: SENAC, 2002. 215 p.

SIQUEIRA, J. O. Microorganismos e processos biologicos do solo: perspectiva ambiental. Brasilia: EMBRAPA, CNPAF, CNPSO, SPI, 1994. 142 p. (EMBRAPA CNPAF. Documentos, 45).

SPOSITO, G.; ZABEL, A. The assessment of soil quality. Geoderma, v. 114, n.3/4, p. 143-144, 2003.

SOLÓRZONO FILHO, J. A. S.; KRAUS, J. E. Breve história das matas de araucária. Forest. v.2 p.37-40, 1999.

SOUZA, M.M.; TRUFEM, S. F.B.; SANDRA M. GOMES-DA-COSTA, S. M. G.; CARDOSO, E. J. B. N. Arbuscular mycorrhizal fungi associated with Araucaria angustifolia (Bert.) O. Ktze. Mycorrhiza, v.13, n.4, p. 211 - 215, Aug. 2003.

STENBERG, B. Monitoring soil quality of arable land: Microbiological indicators. Soil and Plant Science, v. 49, p. 1-24, 1999.

SWISHER, R.; CARROLL, C.G. Fluorescein diacetate hydrolysis as an estimator of microbial biomass on coniferous needle surface. Microbial Ecology, v.6, p.217226, 1980.

TABATABAI, M.A.; BREMNER, J.M. Assay of urease activity in soils. Soil Biology and Biochemistry, v.4, n.4, p.479-487, 1972. 
TAYLOR, J.P.; WILSON, B.; MILLS, M.S.; BURNS, R.G. Comparison of microbial numbers and enzymatic activities in surface soils and subsoils using various techniques. Soil Biology and Biochemistry, v.34, p.387-401, 2002.

VANCE, E.D.; BROOKES, P.C.; JENKINSON, D.S. An extraction method for measuring microbial biomass C. Soil Biology and Biochemistry, v.19, p.703-707, 1987.

VAN GOOR, C. P. Classificação da capacidade da terra em relação ao reflorestamento com Pinus elliotti Eng. Var. elliottii e Araucaria angustifolia (Bert.) O. Ktze., no Estado de São Paulo. Silvicultura em São Paulo, v.4, p. 349-366, 1965.

VICTORIA, R.L.; PICCOLO, M.C.; VARGAS, A.A.T.O ciclo do nitrogênio. In: CARDOSO, E.J.B.N.; TSAI, S.M.; NEVES, M.C. Microbiologia do solo. Campinas: Sociedade Brasileira de Ciência do Solo. Cap. 8, p.105-121, 1992.

WARDLE, D.A. A comparative assessment of factors with influence microbial biomass carbon and nitrogen levels in soil. Biology Review, v.67, p.321-358, 1992.

WARDLE, D. A.; PARKINSON, D. Interactions between microclimatic and the soil microbial biomass. Biology and Fertility of Soils, v.9, n.3, p.273-280, 1990. 